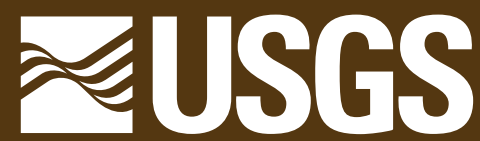

science for a changing world

Prepared in cooperation with the Colorado Water Conservation Board and the Colorado River Water Conservation District

\title{
Simulation of Hydraulic Conditions and Observed and Potential Geomorphic Changes in a Reconfigured Reach of Muddy Creek, North-Central Colorado, 2001-2008
}

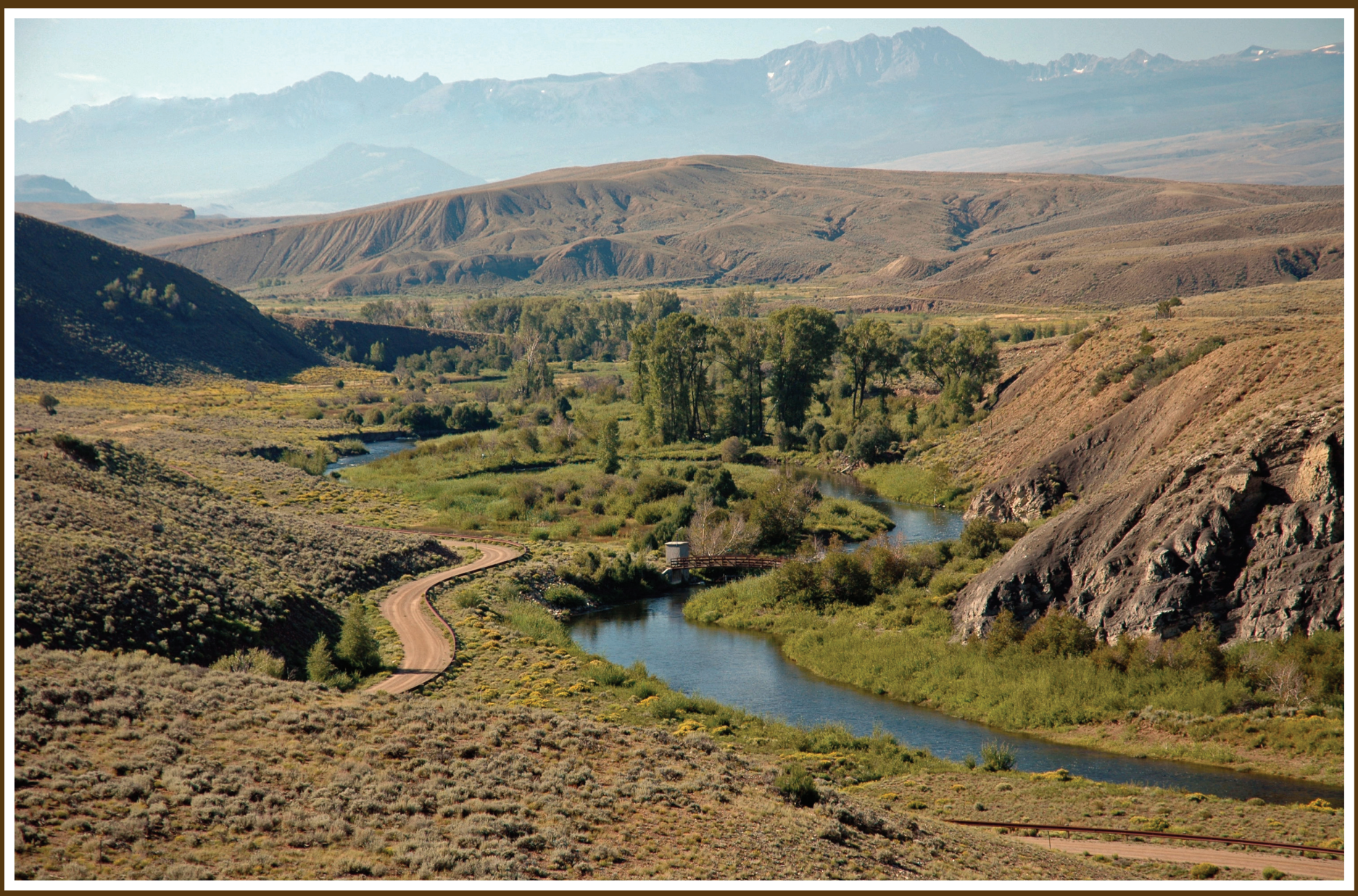

Scientific Investigations Report 2010-5183 


\section{FRONT COVER}

Muddy Creek looking south to the Gore Range and USGS streamflow-gaging station 09041400 Muddy Creek below Wolford Mountain Reservoir, near Kremmling, Colorado.

Photograph by John G. Elliott, U.S. Geological Survey, August 17, 2006. 


\section{Simulation of Hydraulic Conditions and Observed and Potential Geomorphic Changes in a Reconfigured Reach of Muddy Creek, North-Central Colorado, 2001-2008}

By J.G. Elliott, K.R. Schaffrath, R.R. McDonald, C.A. Williams, and K.C. Davis

Prepared in cooperation with the Colorado Water Conservation Board and the

Colorado River Water Conservation District

Scientific Investigations Report 2010-5183 


\title{
U.S. Department of the Interior \\ KEN SALAZAR, Secretary \\ U.S. Geological Survey \\ Marcia K. McNutt, Director
}

\section{U.S. Geological Survey, Reston, Virginia: 2011}

\begin{abstract}
For more information on the USGS — the Federal source for science about the Earth, its natural and living resources, natural hazards, and the environment, visit http://www.usgs.gov or call 1-888-ASK-USGS

For an overview of USGS information products, including maps, imagery, and publications, visit http://www.usgs.gov/pubprod

To order this and other USGS information products, visit http://store.usgs.gov
\end{abstract}

Any use of trade, product, or firm names is for descriptive purposes only and does not imply endorsement by the U.S. Government.

Although this report is in the public domain, permission must be secured from the individual copyright owners to reproduce any copyrighted materials contained within this report.

Suggested citation:

Elliott, J.G., Schaffrath, K.R., McDonald, R.R., Williams, C.A., and Davis, K.C., 2011, Simulation of hydraulic conditions and observed and potential geomorphic changes in a reconfigured reach of Muddy Creek, north-central Colorado, 2001-2008: U.S. Geological Survey Scientific Investigations Report 2010-5183, 43 p. 


\section{Contents}

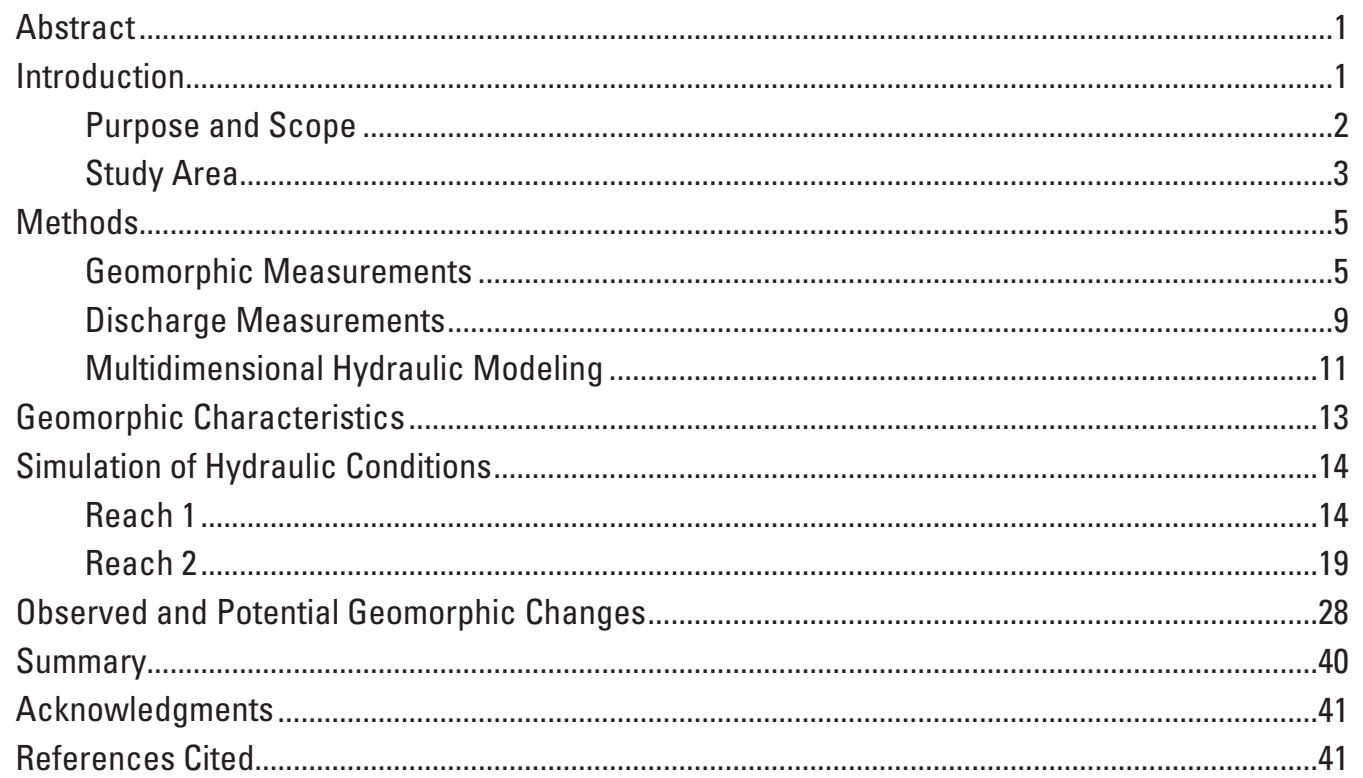

\section{Figures}

1. Map of reconfigured-channel monitoring assessment sites in western Colorado: (1) Muddy Creek below Wolford Mountain Reservoir, near Kremmling, (2) Roaring Fork River at Basalt, (3) Gunnison River at Spann Diversion near Gunnison, (4) Lake Fork at Gateview, (5) North Fork Gunnison River at Hotchkiss, and (6) Uncompahgre River at Ridgway

2. Aerial photograph of Muddy Creek below Wolford Mountain Reservoir near Kremmling, Colorado, showing reaches 1 and 2.

3. Map of Muddy Creek study reach 1 downstream from Wolford Mountain Reservoir near Kremmling, Colorado, showing location of monumented channel cross sections, instrumentation sites, and topographic points surveyed in 2008.

4. Map of Muddy Creek study reach 2 downstream from Wolford Mountain Reservoir near Kremmling, Colorado, showing location of monumented channel cross sections, instrumentation sites, and topographic points surveyed in 2008.

5. Photographs of Muddy Creek in reach 2 showing channel reconfiguration and riprap of the left bank, looking downstream from left bank at cross section 9: (A) Before reconfiguration, May 23, 2001, discharge 2.4 cubic meters per second (83 cubic feet per second), and (B) Five years after reconfiguration, July 30, 2008, discharge 1.2 cubic meters per second (44 cubic feet per second).

6. Photograph of a boulder structure, cross-vane 11.1 in Muddy Creek, reach 2, view looking upstream from right bank below cross section 11, July 30, 2008, at 1.2 cubic meters per second (44 cubic feet per second)

7. Graphical output from an acoustic Doppler current profiler (ADCP) discharge measurement, Muddy Creek reach 1 near cross section 2.

8. Cumulative sediment-size distributions from Muddy Creek 
9-12. Plots of:

9. Muddy Creek cross section 1 downstream from Wolford Mountain Reservoir ..........15

10. Muddy Creek cross section 5 downstream from Wolford Mountain Reservoir ..........15

11. Muddy Creek cross section 9 downstream from Wolford Mountain Reservoir ..........16

12. Muddy Creek cross section 12 downstream from Wolford Mountain Reservoir ........16

13. Longitudinal profile of measured and predicted water-surface elevations from Muddy Creek reach 1, 40, 345, 697, and 928 cubic feet per second.

14. Reach 1 FaSTMECH model solutions for depth with discharge of $(A) 1.13$ cubic meters per second (40 cubic feet per second), (B) 9.77 cubic meters per second (345 cubic feet per second), (C) 19.7 cubic meters per second (697 cubic feet per second), and $(D) 26.3$ cubic meters per second (928 cubic feet per second) ...........20

15. Reach 1 FaSTMECH model solutions for velocity with discharge of $(A) 1.13$ cubic meters per second (40 cubic feet per second), (B) 9.77 cubic meters per second ( 345 cubic feet per second), (C) 19.7 cubic meters per second (697 cubic feet per second), and (D) 26.3 cubic meters per second (928 cubic feet per second)...

16. Reach 1 FaSTMECH model solutions for bed shear stress with discharge of (A) 1.13 cubic meters per second (40 cubic feet per second), (B) 9.77 cubic meters per second (345 cubic feet per second), (C) 19.7 cubic meters per second (697 cubic feet per second), and (D) 26.3 cubic meters per second (928 cubic feet per second).

17. Reach 1 FaSTMECH model solutions for sediment-transport strength with discharge of $(A) 1.13$ cubic meters per second ( 40 cubic feet per second), (B) 9.77 cubic meters per second (345 cubic feet per second), (C) 19.7 cubic meters per second (697 cubic feet per second), and (D) 26.3 cubic meters per second (928 cubic feet per second)

18. Longitudinal profile of measured and predicted water-surface elevations from Muddy Creek reach 2, 44, 343, 697, and 968 cubic feet per second.

19. Reach 2 FaSTMECH model solutions for depth with discharge of $(A) 1.25$ cubic meters per second (44 cubic feet per second), (B) 9.71 cubic meters per second (343 cubic feet per second), (C) 19.7 cubic meters per second (697 cubic feet per second), and (D) 27.4 cubic meters per second (968 cubic feet per second)....

20. Reach 2 FaSTMECH model solutions for velocity with discharge of $(A) 1.25$ cubic meters per second (44 cubic feet per second), (B) 9.71 cubic meters per second (343 cubic feet per second), (C) 19.7 cubic meters per second (697 cubic feet per second), and (D) 27.4 cubic meters per second (968 cubic feet per second)

21. Reach 2 FaSTMECH model solutions for bed shear stress with discharge of (A) 1.25 cubic meters per second (44 cubic feet per second), (B) 9.71 cubic meters per second (343 cubic feet per second), (C) 19.7 cubic meters per second (697 cubic feet per second), and (D) 27.4 cubic meters per second (968 cubic feet per second).

22. Reach 2 FaSTMECH model solutions for sediment-transport strength with discharge of $(A) 1.25$ cubic meters per second (44 cubic feet per second), (B) 9.71 cubic meters per second (343 cubic feet per second), (C) 19.7 cubic meters per second (697 cubic feet per second), and (D) 27.4 cubic meters per second (968 cubic feet per second)

23. FaSTMECH model solution showing depth and velocity vectors at boulder cross vane near cross section 11 with discharge of $(A) 1.25$ cubic meters per second (44 cubic feet per second), (B) 9.71 cubic meters per second (343 cubic feet per second), (C) 19.7 cubic meters per second (697 cubic feet per second), and (D) 27.4 cubic meters per second (968 cubic feet per second) 


\section{Tables}

1. Annual peak discharge recorded at USGS streamflow-gaging station 09041400 Muddy Creek below Wolford Mountain Reservoir near Kremmling, Colorado, water years 1996-2008...

2. Muddy Creek FaSTMECH boundary conditions and model parameters for best-solution simulations

\section{Conversion Factors}

SI to Inch/Pound

\begin{tabular}{lcc}
\hline Multiply & By & To obtain \\
\hline millimeter $(\mathrm{mm})$ & Length & \\
meter $(\mathrm{m})$ & 0.03937 & inch (in.) \\
kilometer $(\mathrm{km})$ & 3.281 & foot $(\mathrm{ft})$ \\
\hline & 0.6214 & mile (mi) \\
\hline hectare $($ ha) & Area & acre \\
hectare $($ ha) & 2.471 & square mile $\left(\mathrm{mi}^{2}\right)$ \\
square kilometer $\left(\mathrm{km}^{2}\right)$ & 0.003861 & square mile $\left(\mathrm{mi}^{2}\right)$ \\
\hline & 0.3861 & acre-foot $\left(\right.$ acre- $\left.\mathrm{ft}^{2}\right)$ \\
\hline cubic hectometer $\left(\mathrm{hm}^{3}\right)$ & Volume & cubic foot per second $\left(\mathrm{ft}^{3} / \mathrm{s}\right)$ \\
\hline cubic meter per second $\left(\mathrm{m}^{3} / \mathrm{s}\right)$ & 810.7 & \\
\hline megagram per year $(\mathrm{Mg} / \mathrm{yr})$ & Flow rate & ton per year $(\mathrm{ton} / \mathrm{yr})$ \\
\hline newton per square $\mathrm{meter}\left(\mathrm{N} / \mathrm{m}^{2}\right)$ & 35.31 & pound per square foot $\left(\mathrm{lb} / \mathrm{ft}^{2}\right)$ \\
\hline gram per cubic centimeter $\left(\mathrm{g} / \mathrm{cm}^{3}\right)$ & 1.102 & pound per cubic foot $\left(\mathrm{lb} / \mathrm{ft}^{3}\right)$ \\
\hline
\end{tabular}

Vertical coordinate information is referenced to the North American Vertical Datum of 1988 (NAVD 88).

Horizontal coordinate information is referenced to the North American Datum of 1983 (NAD 83).

Water year is a continuous period from October 1 to September 30 with the year of designation determined by the ending calendar year. 



\title{
Simulation of Hydraulic Conditions and Observed and Potential Geomorphic Changes in a Reconfigured Reach of Muddy Creek, North-Central Colorado, 2001-2008
}

\author{
By John G. Elliott, Keelin R. Schaffrath, Richard R. McDonald, Cory A. Williams, and Kyle C. Davis
}

\begin{abstract}
Muddy Creek near Kremmling, Colorado, is a regulated, meandering, gravel-bed stream that has been monitored for geomorphic change since 2001. One reach of the creek was reconfigured using "natural-channel design" methods in 2003, providing an opportunity to compare hydraulics in this reach with those in a nearby, unaltered control reach. Streamflow in Muddy Creek has been regulated by Wolford Mountain Reservoir since 1995, but reservoir releases in 2006 and 2008 resulted in out-of-bank floods. The Muddy Creek monitoring program was conducted by the U.S. Geological Survey from 2001 to 2008 in cooperation with the Colorado River Water Conservation District, and the streamflow modeling and analysis were conducted in 2008 in cooperation with the Colorado River Water Conservation District and the Colorado Water Conservation Board.

Minor changes in channel geometry were measured at monitored cross sections in the control reach between 2001 and 2008 and in the reconfigured reach between 2003 and 2008. Geomorphic changes were limited to lateral erosion in a meander bend and lateral erosion of an alluvial fan that formed a vertical scarp in the control reach. Some excavated streambed locations in the reconfigured reach have aggraded to their former elevations, and gravel on alluvial bars might have become better sorted and winnowed of sand-size sediment. Hydraulic conditions in the reconfigured and control reaches were simulated using the U.S. Geological Survey MD_SWMS framework and FaSTMECH computational models. Model topography was created from onsite surveys, and model simulations were calibrated with surveyed water-surface elevations and the corresponding discharges for low, medium, high, and out-of-bank flood discharges. The simulations produced 2-dimensional estimates for depth, velocity, bed shear stress, and sedimenttransport strength for each discharge. High bed shear stresses generally occurred in areas of the greatest depth and velocity, such as in meander bends (where depths were greater) and in steeper gradient areas (where velocities were greater).

The transport-strength solution represented the potential for sediment entrainment and transport. Transport-strength solutions indicated that widespread entrainment of the streambed
\end{abstract}

median particle size $\left(\mathrm{d}_{50}\right)$ likely occurs only in isolated subreaches at discharges slightly above bankfull conditions in both the control and reconfigured reaches. Onsite observations after the 2008 flood peak generally supported model simulations that indicated sediment mobility in limited areas predominantly at high and out-of-bank discharges. The limited areas of potential streambed mobility identified by the model simulations and onsite observations indicate that the Muddy Creek channel in the reconfigured and control reaches is relatively stable at discharges up to and slightly greater than the approximate "bankfull" discharge.

Boulder cross-vane structures of the type used in "naturalchannel design" reconfiguration projects redirected and concentrated streamflow threads at all simulated discharges and created localized areas of high bed-shear stress. However, the minor channel changes from 2003 to 2008 in the reconfigured reach were comparable to the minor changes in the control reach during the same time period, indicating these structures might not have been necessary to maintain the channel pattern and position in the Muddy Creek reconfigured reach.

\section{Introduction}

Intentional channel modification to mitigate a variety of riverine conditions has become a widespread practice in the Western United States. Channel modifications fall into three broad and somewhat overlapping categories.

1. Restoration, as applied to stream corridors that have been altered through human activity, is the attempt to recreate the physical and biological conditions that were present before the human alteration. A goal of restoration is to eliminate the effects of human-induced alteration (Osterkamp, 2008).

2. Rehabilitation, as applied to stream corridors, is the establishment of a condition of health and constructive activity. A goal of rehabilitation is to minimize, not eliminate, the effects of human-induced alteration, thus promoting stable channel form, bioproductivity, and species diversity (Osterkamp, 2008). 
3. Reconfiguration, as applied to stream corridors, is the alteration of channel form (geomorphology) in an attempt to alter the channel function (such as streamflow conveyance, sediment transport, and habitat), stability (such as meander migration rate, bank erosion, and streambed incision), or esthetics (such as channel pattern and channel type). A goal of reconfiguration is to create a channel morphology that, subsequently, results in the desired stream function, stability, or esthetics.

Reasons cited for intentional channel modifications include restoration of historical conditions, rehabilitation to more "natural" conditions, improved water conveyance in flood-prone areas, mitigation of unstable streambed and streambanks, efficient transport of supplied sediment, rehabilitation of habitat, or enhancement of recreation. Because of the broad scope and multiple objectives of most channel modification activities, the term "channel reconfiguration" is used to describe the examples cited in this report.

Many private entities and resource-management agencies have reconfigured stream and river channels by using designs based on different geomorphic philosophies and classification schemes (Mosley, 1982; Miall, 1985; Montgomery and Buffington, 1993; Whiting and Bradley, 1993; Rosgen, 1996; Federal Interagency Stream Restoration Working Group, 2001). Many kilometers of stream channels in Colorado and the Western United States have been reconfigured; however, geomorphic response to, and the hydraulic function of, these modifications over a period of time have not been assessed in a consistent manner (Kondolf and Micheli, 1995; Kondolf, 1998).

Some stream-channel reaches reconfigured using the "natural-channel design" criteria (Rosgen, 2006 and 2007) exhibit unanticipated or undesirable geomorphic changes after the conveyance of discharges of greater than bankfull magnitude (Kochel and others, 2005; Elliott and Capesius, 2009). These include continued lateral erosion and meander-bend migration, entrainment and dislodging of boulder and log habitat and flow-directing structures, and sedimentation near and on these structures. Problems originating from the use of a natural-channel design approach in river rehabilitation, or reconfiguration, generally tend to be related to (1) the assumption that the function of the reconfigured channel will follow its imposed reconfigured morphology; (2) the use of fixedlocation boulder and log structures and riprap in a dynamic river channel; (3) strict correlation of channel form (such as width, depth, and meander wavelength) with a single discharge value (for example, the bankfull discharge) commonly estimated from a "reference reach" assumed to have characteristics similar to the desired reconfigured channel; (4) failure to account for natural variability in channel morphology over time; (5) failure to account for the imbalance in driving and resisting forces or sediment supply and transport capacity; or (6) design focus only on average channel conditions at the reach scale (Juracek and Fitzpatrick, 2003; Smith and Prestegaard, 2005; Simon and others, 2007).
The U.S. Geological Survey (USGS) ReconfiguredChannel Monitoring and Assessment Program (RCMAP) (Elliott and Parker, 1999) is designed to monitor and evaluate geomorphic conditions and changes in selected river reaches that have undergone intentional channel modifications. Monitoring activities of the RCMAP include obtaining replicate topographic channel surveys and photographs, and collecting streambed-sediment data for reaches of several reconfigured western Colorado rivers (fig. 1). The monitoring activities are conducted using field methods commonly used by geomorphologists (Wolman, 1954; Dunne and Leopold, 1978; Harrelson and others, 1994; Kondolf and Micheli, 1995; Fitzpatrick and others, 1998; Smelser and Schmidt, 1998).

Data and photographs for monitored reaches are posted on the RCMAP Web site, http://co.water.usgs.gov/projects/rcmap/ index. html (accessed April 28, 2010). Periodically, data from the monitored reaches are evaluated and analyzed to assess geomorphic responses to hydrologic conditions and events (Elliott and Capesius, 2009).

One of the reconfigured reaches selected for analysis is Muddy Creek, a meandering, gravel-bed stream downstream from Ritschard Dam and Wolford Mountain Reservoir near Kremmling, Colorado. The study area includes an unaltered "control" reach (reach 1) and a nearby reach that was reconfigured in 2003 using the natural-channel-design approach (reach 2) (fig. 2). The goals of the study were to

1. monitor and quantify geomorphic changes in Muddy Creek related to controlled streamflow releases from Ritschard Dam,

2. compare geomorphic changes in a reach that was reconfigured using the natural-channel design approach with changes in an unaltered control reach, and

3. simulate hydraulic conditions of Muddy Creek for a range of discharges and examine the function of the naturalchannel design approach in a meandering gravel-bed stream.

The Muddy Creek monitoring program was conducted by the USGS from 2001 to 2008 in cooperation with the Colorado River Water Conservation District (CRWCD), and the streamflow modeling and analysis were conducted in 2008 in cooperation with the CRWCD and the Colorado Water Conservation Board.

\section{Purpose and Scope}

The purpose of this report is to describe geomorphic characteristics, simulations of hydraulic conditions, and potential for geomorphic changes in an unaltered (control) reach and a nearby reconfigured reach of Muddy Creek near Kremmling, Colorado. Geomorphic monitoring in both reaches was conducted from 2001 through 2008 and consisted of replicate topographic surveys and photographs and several streambed-sediment measurements. Channel hydraulic conditions were measured in 2008 and subsequently were simulated in both reaches using a multidimensional, computational streamflow model in 2009. The Multi-Dimensional 


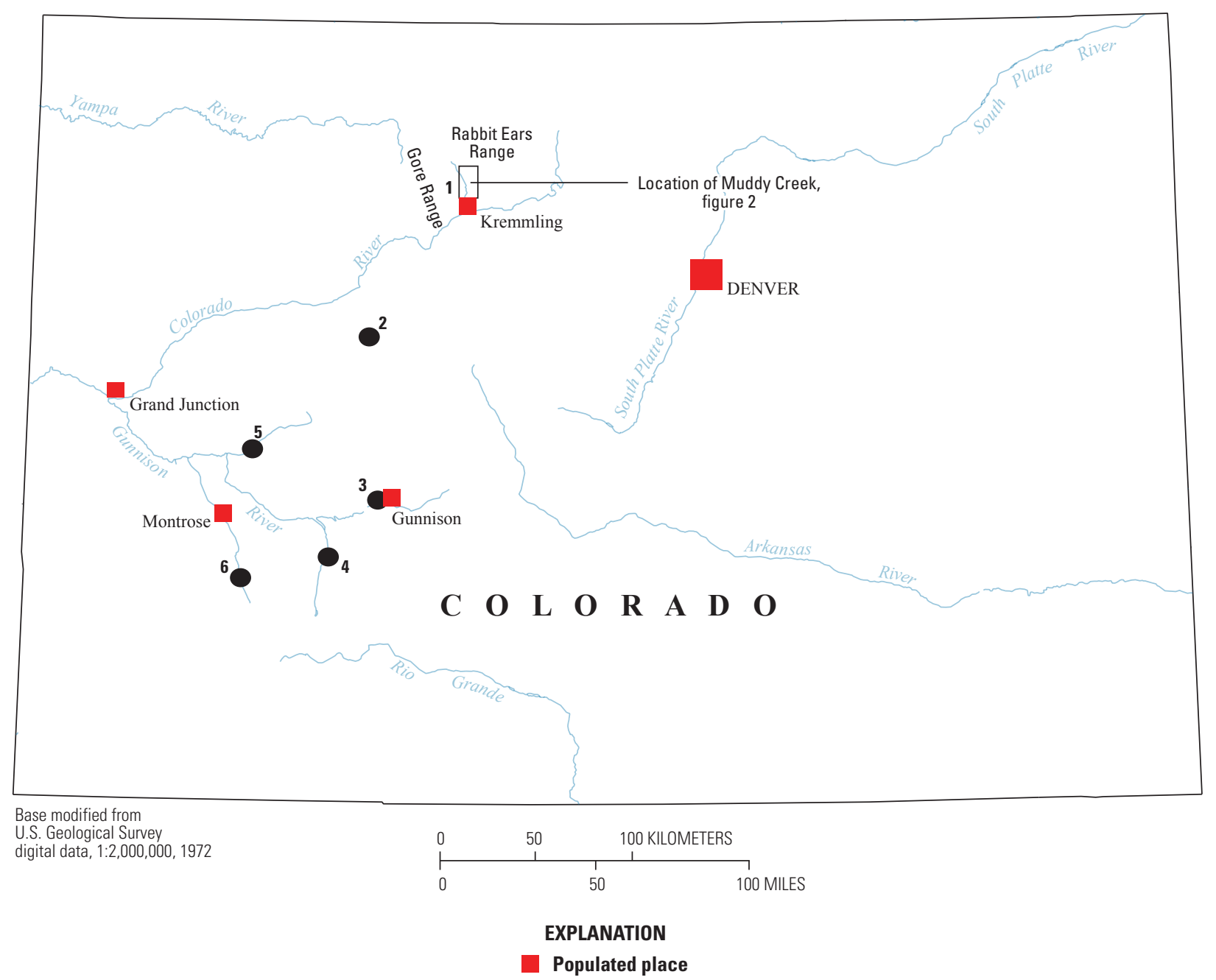

Figure 1. Reconfigured-channel monitoring assessment sites in western Colorado: (1) Muddy Creek below Wolford Mountain Reservoir, near Kremmling, (2) Roaring Fork River at Basalt, (3) Gunnison River at Spann Diversion near Gunnison, (4) Lake Fork at Gateview, (5) North Fork Gunnison River at Hotchkiss, and (6) Uncompahgre River at Ridgway.

Surface-Water Modeling System (MD_SWMS) and the steady-state flow computational model FaSTMECH, developed by the USGS (Nelson and others, 2003; McDonald and others, 2005a and 2005b), were used to simulate Muddy Creek hydraulics.

Input and output from the FaSTMECH model are in international system (SI) units. Therefore, descriptions of the Muddy Creek simulations are in SI units, with the exception of discharge, which is presented in inch/pound units for the reader's convenience. Tables for conversion of SI units to inch/pound units and inch/pound to SI units are provided in the beginning of this report.

\section{Study Area}

Muddy Creek and its major tributaries originate in the Gore Range and Rabbit Ears Range of north-central Colorado (fig. 1). The study area is in the lower-elevation part of the Muddy Creek basin and is underlain by marine shales. Mean annual precipitation ranges from 635 to $1,270 \mathrm{~mm}$ in the headwaters portion of the watershed and from 305 to $635 \mathrm{~mm}$ in the lower watershed (Stevens and Sprague, 2003).

Muddy Creek runoff is derived primarily from snowmelt, but in the lower reaches, including the RCMAP monitored reaches, streamflow is regulated entirely by releases and spills from Ritschard Dam and Wolford Mountain Reservoir (fig. 2). The dam was constructed from 1992 to 1994, and the reservoir began filling in 1995. Wolford Mountain Reservoir has an $84-\mathrm{hm}^{3}$ storage capacity and covers approximately 610 ha at full storage (Stevens and Sprague, 2003). When filled to capacity, typically during April through June, additional inflow passes through the reservoir and, since 1995, creates the annual discharge peak in Muddy Creek.

Two studies of potential reservoir effects on Muddy Creek were published before the construction of Wolford Mountain Reservoir. Ruddy (1987) estimated that the mean annual total-sediment discharge in Muddy Creek near Kremmling ranged between 58,800 and 99,800 Mg/yr and averaged 75,300 Mg/yr for the period 1983 through 1985. At 


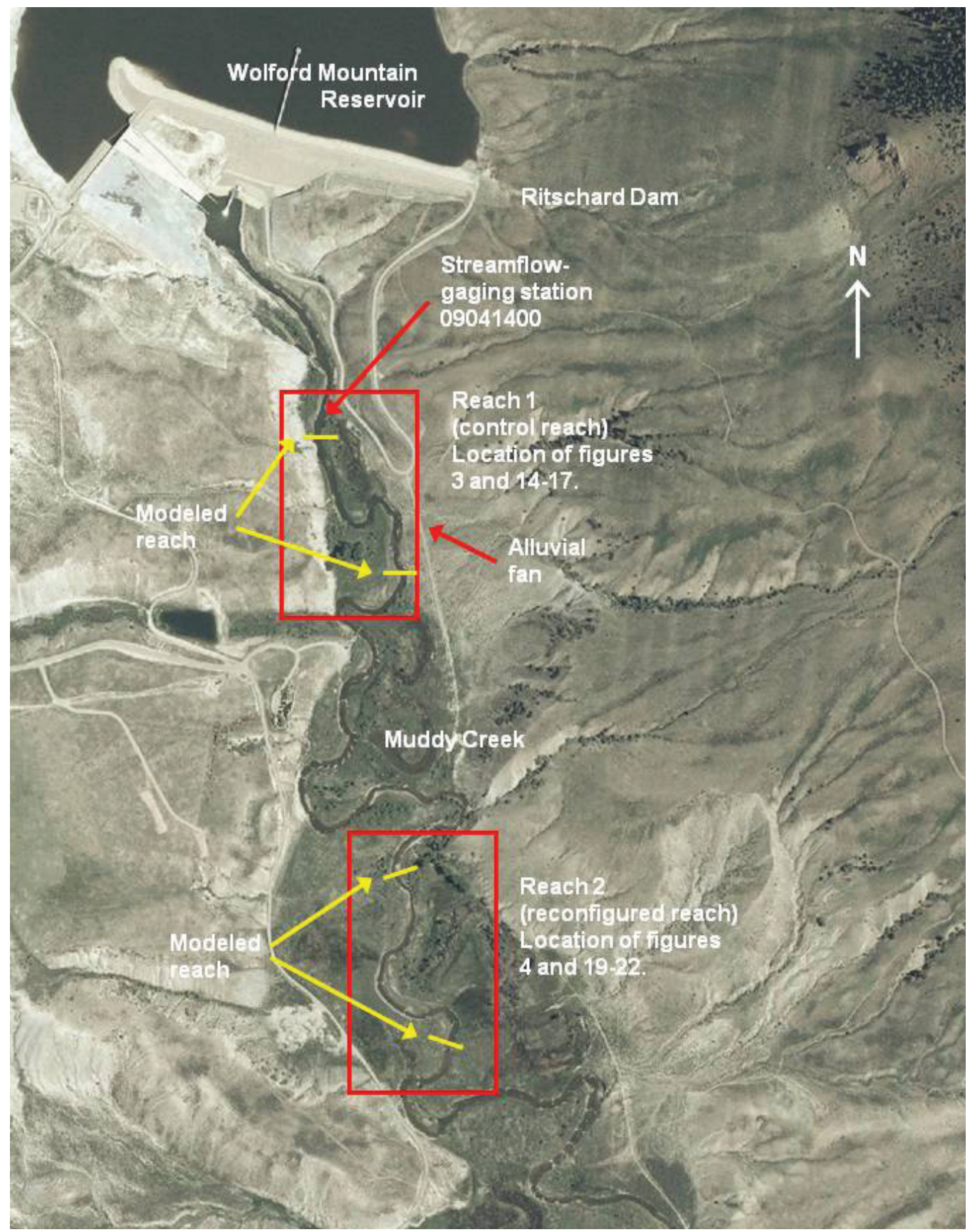

Figure 2. Muddy Creek below Wolford Mountain Reservoir near Kremmling, Colorado, showing reaches 1 and 2.

least 97 percent of the total-sediment discharge was transported in the suspended phase. Among the estimated downstream effects of a proposed Wolford Mountain Reservoir was channel degradation of about $0.12 \mathrm{~m}$ in the $210 \mathrm{~m}$ immediately downstream from the proposed dam site (Butler, 1990).

Regulation by the reservoir has had an attenuating effect on annual variation in stream-water temperature, and turbidity was substantially reduced as a result of reservoir sedimentation. Peak discharges downstream from the reservoir were the same or slightly less than peak discharges upstream from the reservoir; however, the duration of the largest discharges (greater than the upper 15th percentile) downstream from the reservoir decreased, whereas the duration of moderate and low discharges increased as a result of reservoir operation (Stevens and Sprague, 2003).

Discharge data have been collected at USGS streamflowgaging station 09041400 Muddy Creek below Wolford Mountain Reservoir near Kremmling, Colorado, since July 1995. The gage is located approximately $460 \mathrm{~m}$ downstream from Ritschard Dam and $6.5 \mathrm{~km}$ northwest of Kremmling in the northwest 
quarter of the southeast quarter of section 25, T. 2 N., R. 81 W., at an elevation of about 2,250 m (datum NGVD of 1929). The drainage area of the watershed upstream from the gage is about $700 \mathrm{~km}^{2}$. The maximum instantaneous peak discharge recorded at the gage was $1,030 \mathrm{ft}^{3} / \mathrm{s}\left(29.2 \mathrm{~m}^{3} / \mathrm{s}\right)$ on June 2, 1997. Annual peak discharges during the period of this study ranged from $217 \mathrm{ft}^{3} / \mathrm{s}\left(6.14 \mathrm{~m}^{3} / \mathrm{s}\right)$ in 2003 to $968 \mathrm{ft}^{3} / \mathrm{s}\left(27.4 \mathrm{~m}^{3} / \mathrm{s}\right)$ in 2008 (http://nwis.waterdata.usgs.gov/co/nwis/peak/accessed June 18, 2010).

A reference bankfull discharge was not determined for the monitoring reaches because Muddy Creek streamflow has been heavily regulated since 1995 . Annual peak discharges since 2001 were contained within the existing channel, with the exception of annual peaks in $2006,917 \mathrm{ft}^{3} / \mathrm{s}\left(26.0 \mathrm{~m}^{3} / \mathrm{s}\right)$ and 2008, $968 \mathrm{ft}^{3} / \mathrm{s}\left(27.4 \mathrm{~m}^{3} \mathrm{~s}\right)$, which were well above relict bank and point-bar surfaces that likely were established before 1995 .

Muddy Creek downstream from Wolford Mountain Reservoir is a meandering, gravel-bed stream with an average "bankfull" channel width of approximately $16.5 \mathrm{~m}$. The Muddy Creek study area begins approximately $0.5 \mathrm{~km}$ downstream from the Ritschard Dam and consists of two actively monitored reaches (fig. 2). Reach 1 is unaltered, whereas reach 2 , downstream from reach 1 , was mechanically altered by reconfiguration with channel stabilization and flow-directing boulder structures (the natural-channel design approach). Both reaches are affected by the upstream reservoir.

Reach 1 is a sinuous, 490-m-long (channel length), unaltered "control" reach that begins at the USGS streamflowgaging station (fig. 3 ) and continues downstream to the boundary of the privately owned Grand River Ranch. Reach 2 is a sinuous, 530-m-long (channel length), reconfigured reach of the creek beginning approximately $380 \mathrm{~m}$ (valley length) downstream from reach 1 and approximately $1.1 \mathrm{~km}$ downstream from Ritschard Dam (fig. 4). Reach 1 is on Bureau of Land Management (BLM) land and is accessible to the public; however, reach 2 is on private property and access is restricted.

Reach 2, the reconfigured reach, was modified in the fall of 2003 by the landowner to enhance and improve aquatic habitat. Reconfiguration activities included excavating and lowering the streambed in some locations and installation of numerous flow-directing rock structures. The channel pattern (for example, sinuosity, meander radius of curvature, meander wavelength, and channel alignment) in reach 2 was not changed from the 2001 channel pattern during reconfiguration activities. However, boulder riprap and log crib work were added to some streambanks to prevent bank erosion and meander migration, and the angle of some cut-bank scarps above the riprap was reduced from near vertical to a lesser slope (fig. 5). Willow seedlings and cottonwood saplings were planted along some of the banks and in the riparian zone to enhance stability. Numerous boulder grade-control and flow-directing structures called "cross vanes" and "rock vanes" (Rosgen, 2001) were constructed in the channel in late 2003 (fig. 6). Other individual boulders were placed randomly in the channel to create flow variability and to enhance aquatic habitat.

\section{Methods}

Geomorphic characteristics and changes in Muddy Creek were observed over several years and were quantified through replicate topographic surveys and photography (Elliott and Parker, 1999). Bed-material sediment-size characteristics were determined with Wolman pebble counts of the streambed and alluvial bars (Wolman, 1954). Hydraulic characteristics of Muddy Creek were determined for a range of streamflow conditions by measuring discharge, velocity, and water-surface elevation, and by using a multidimensional streamflow model. Hydraulic characteristics in the vicinity of installed flowdirecting boulder structures in reach 2 also were evaluated with the multidimensional streamflow model.

\section{Geomorphic Measurements}

Standard geomorphic field techniques were used to quantify Muddy Creek channel characteristics (Elliott and Parker, 1999) and are described in the RCMAP Monitoring Methods Web site http://co.water.usgs.gov/projects/rcmap/ monitormethods.html (accessed April 28, 2010). The U.S. Department of Agriculture, Forest Service General Technical Report RM-245 (Harrelson and others, 1994) also provides guidelines for basic surveying techniques, identification of bankfull indicators, and measurement of other important stream characteristics. Replicate channel surveys of Muddy Creek were made over a period of years by using a common datum and coordinate system to quantify geomorphic changes that occurred as a result of streambed scour, bedmaterial aggradation, or lateral channel migration (Emmett and Hadley, 1968). The time interval between replicate measurements was determined by the hydrologic history and geomorphic response of the monitored reach.

Reaches 1 and 2 were monumented and surveyed during low-discharge periods by the USGS as part of the RCMAP in 2001. Reach 2 was resurveyed and photographed by the USGS in October 2003, immediately after channel modifications were completed. No channel modifications were made in reach 1; consequently, no measurements were made in reach 1 in 2003. Replicate surveys of both reaches were made in August 2006 after a peak discharge of $917 \mathrm{ft}^{3} / \mathrm{s}$ at the USGS streamflow-gaging station 09041400 and in August 2008 after a peak discharge of $968 \mathrm{ft}^{3} / \mathrm{s}$. Sediment measurements were made in 2003 and 2008.

The 2001 and 2003 channel surveys were made using a Topcon total-station, and the 2006 and 2008 surveys were made using a Trimble real-time kinetic (RTK) global-positioning system (GPS) surveying instrument. All surveys were rectified retroactively to a common coordinate system and datum. The 2006 RTK GPS survey was submitted to the National Geodetic Survey's Online Positioning Users Service (OPUS) Web site for processing (http://www.ngs.noaa.gov/OPUS/). Data from all surveys were rectified to the OPUS solution. The coordinate 


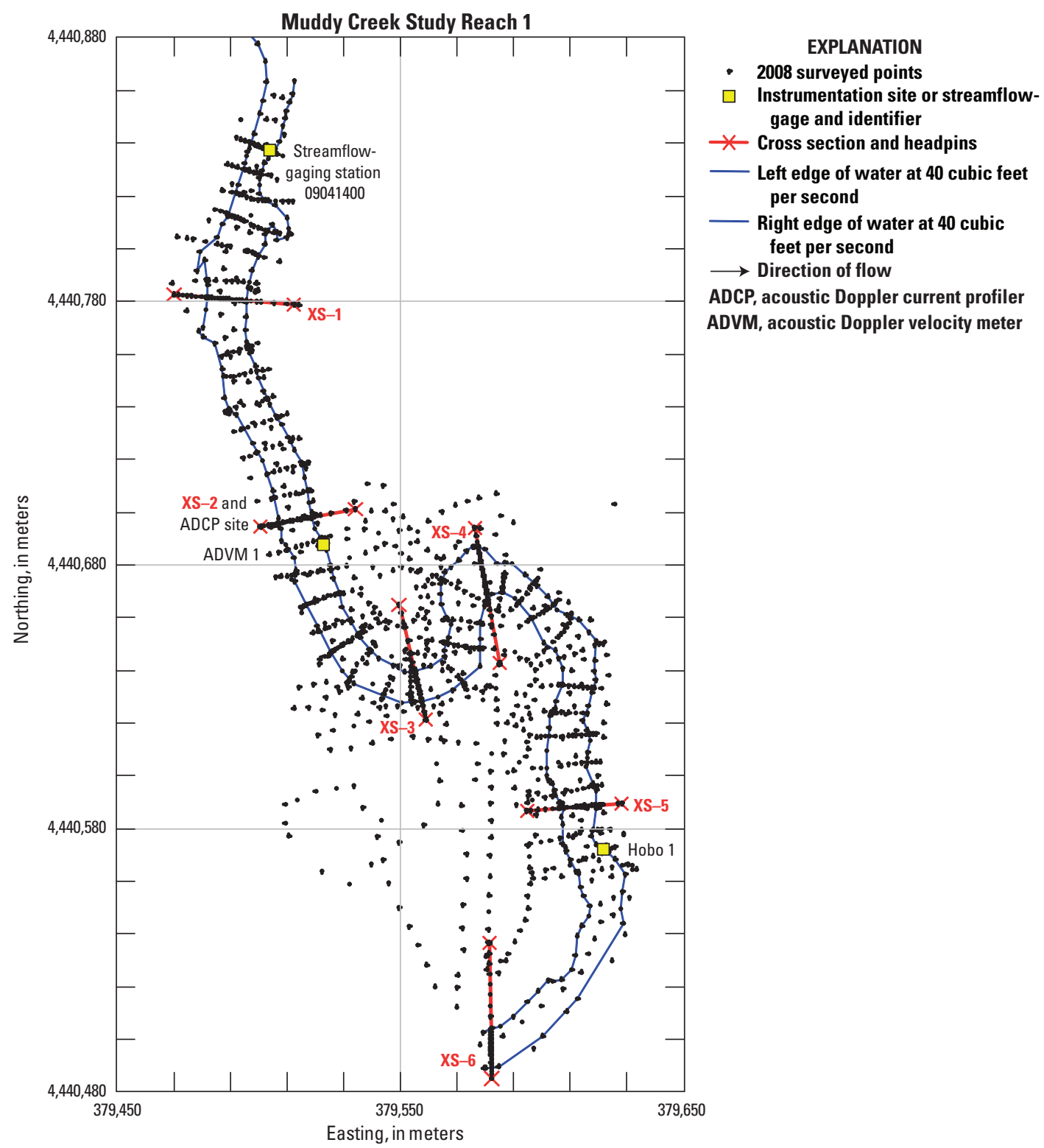

Figure 3. Muddy Creek study reach 1 downstream from Wolford Mountain Reservoir near Kremmling, Colorado, showing location of monumented channel cross sections, instrumentation sites, and topographic points surveyed in 2008. Flow is north to south.

system was Universal Transverse Mercator (UTM) Zone 13 North, horizontal datum North American Datum (NAD) of 83 (meters), vertical datum North American Vertical Datum (NAVD) of 88, Geoid 03, ellipsoid World Geodetic System (WGS) 84.

Monitoring cross sections were established in 2001 and were spaced at approximately three to six channel widths apart. Cross sections 1 through 6 were in reach 1, and cross sections 7 through 15 were in reach 2 . Endpoints of each cross section were monumented with rebar (cross-section headpins), and coordinates were recorded to facilitate replicate surveys. Longitudinal-profile surveys of the water surface, high-water marks, and streambanks were made in addition to cross-section surveys.

Streambed, bank, alluvial-bar, and flood-plain points were surveyed in 2008 to create the topographic surface used in the hydraulic model simulations. Along with the 15 monitoring cross sections, several additional traverses across the channel were surveyed between the monumented cross sections to provide additional topographic detail of the streambed (figs. 3 and 4). Two longitudinal transects of the streambed were surveyed approximately parallel to the streambanks in 


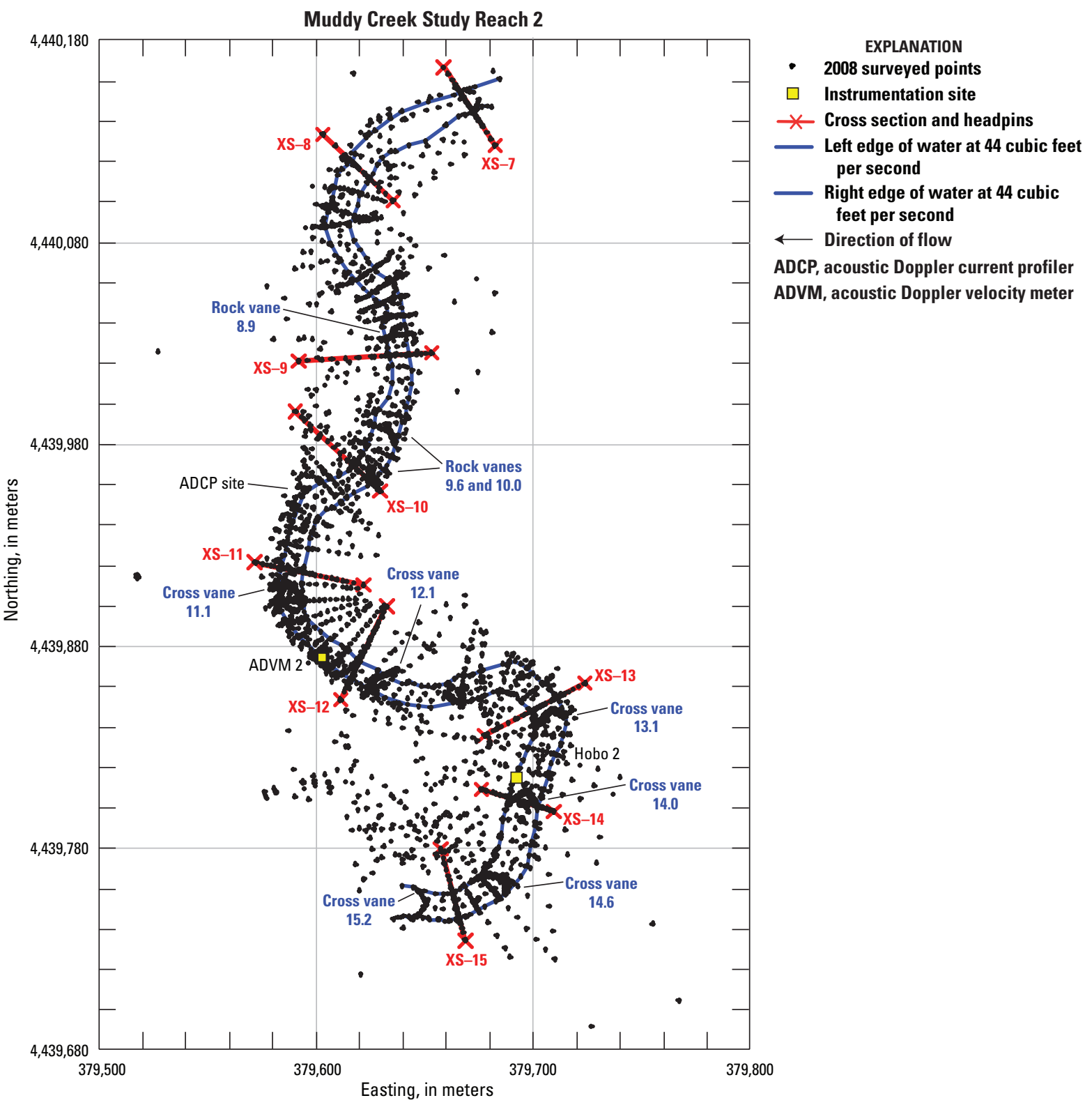

Figure 4. Muddy Creek study reach 2 downstream from Wolford Mountain Reservoir near Kremmling, Colorado, showing location of monumented channel cross sections, instrumentation sites, and topographic points surveyed in 2008. Flow is north to south.

reaches 1 and 2. Additional points were surveyed on and adjacent to the boulder structures in reach 2 because of their effect on streamflow direction, velocity, and roughness.

The water-surface elevations for four discharges, measured in each reach, were surveyed between July 28 and August 1, 2008. The low-discharge water-surface elevation was surveyed directly during this period, whereas, watersurface elevations of the greater discharges were marked with a nail and plastic flagging earlier in the year and subsequently surveyed between July 28 and August 21, 2008 (Benson and Dalrymple, 1967). The reach 1 discharges were 40, 345, 697, and $928 \mathrm{ft}^{3} / \mathrm{s}\left(1.13,9.77,19.7,26.3 \mathrm{~m}^{3} / \mathrm{s}\right)$, and the reach 2 discharges were $44,343,697$, and $968 \mathrm{ft}^{3} / \mathrm{s}(1.25,9.71,19.7$, $27.4 \mathrm{~m}^{3} / \mathrm{s}$ ). The water surfaces at 40 and $44 \mathrm{ft}^{3} / \mathrm{s}$ represented low-flow, late-season discharges and were surveyed in July and August 2008. The 343- and 345- $\mathrm{ft}^{3} / \mathrm{s}$ discharges were flagged on June 18, 2008, and represented moderate discharge in the study reaches. The $697-\mathrm{ft}^{3} / \mathrm{s}$ discharge was flagged on May 30, 2008, and represented a high discharge that nearly filled the channel to the tops of its banks. The flagged water surfaces corresponding to these moderate and high discharges were surveyed along with the channel topography 

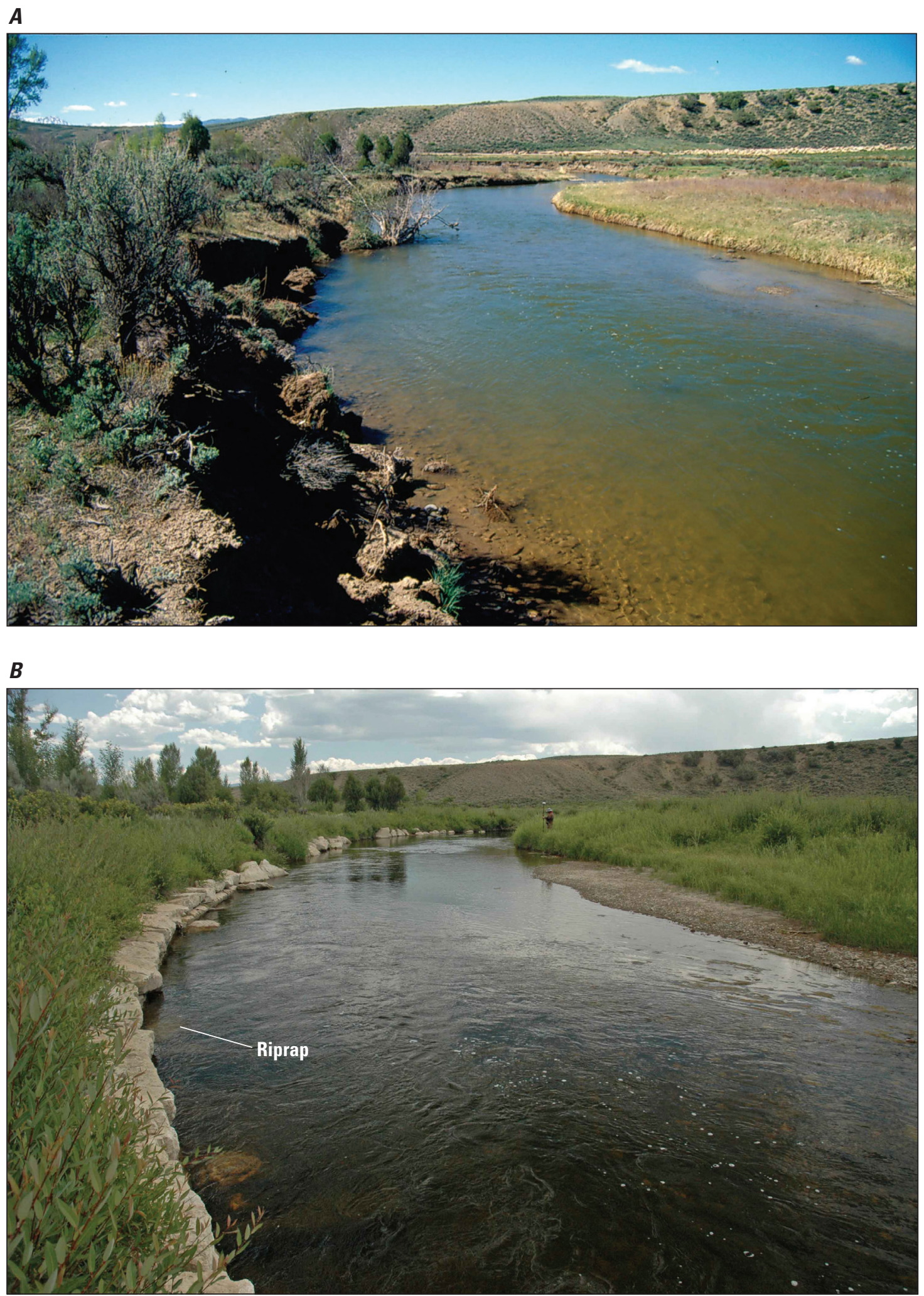

Figure 5. Muddy Creek in reach 2 showing channel reconfiguration and riprap of the left bank, looking downstream from left bank at cross section 9: (A) Before reconfiguration, May 23, 2001, discharge 2.4 cubic meters per second ( 83 cubic feet per second), and (B) five years after reconfiguration, July 30,2008 , discharge 1.2 cubic meters per second (44 cubic feet per second). 


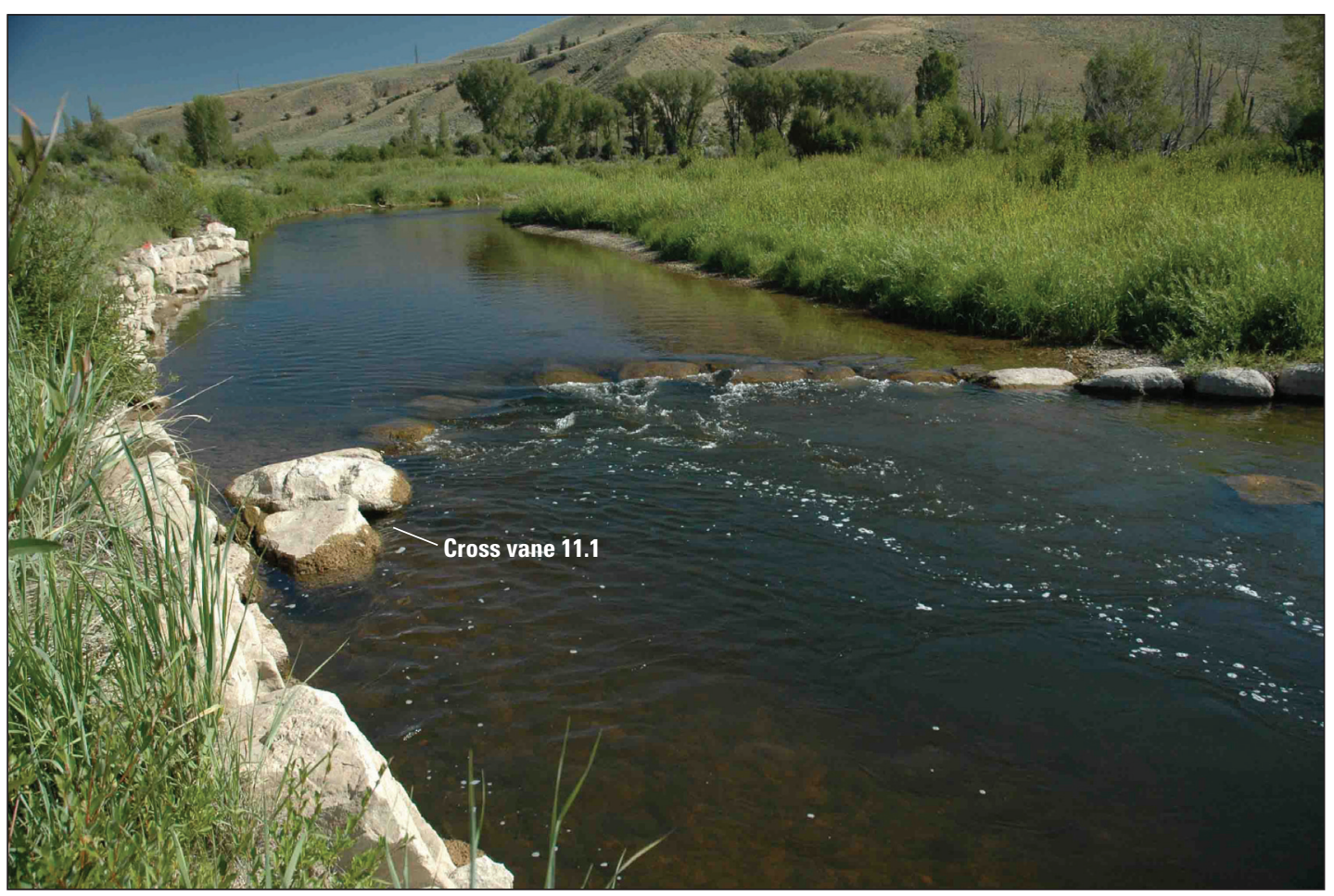

Figure 6. A boulder structure, cross-vane 11.1 in Muddy Creek, reach 2, view looking upstream from right bank below cross section 11, July 30, 2008, at 1.2 cubic meters per second (44 cubic feet per second).

and low-discharge water surface in July and August 2008. The 2008 instantaneous annual peak discharge was $968 \mathrm{ft}^{3} / \mathrm{s}$, and water at this discharge overtopped the streambanks and covered the adjacent flood plain in many places on May 20, 2008. The water-surface elevation in reach 2 was flagged at the peak discharge; whereas, the water-surface elevation in reach 1 was flagged at a discharge of $928 \mathrm{ft}^{3} / \mathrm{s}$ a few hours earlier on the same day. High-water marks, composed of organic flotsam (grass and leaves) and slack-water sediment deposits (silt and sand), from the discharge peak were identified and surveyed during the July and August 2008 visits.

Sediment characteristics were determined for the streambed and alluvial bars in the two monitoring reaches to characterize the range of sediment-particle sizes typical of different geomorphic surfaces and available for transport within the channel. Sediment particle-size measurements were made at four streambed and two alluvial bar locations using the Wolman pebble-count method (Wolman, 1954). Most particle measurements were made by sampling the streambed or alluvial bars at approximately 100 regularly spaced points along linear transects parallel to the direction of streamflow; however, measurements on submerged riffles were made by a nonlinear, random-path method (Elliott and Parker, 1999). The intermediate, or "b-axis," of the sediment particle was measured with a graduated scale to the nearest millimeter for gravel and small cobbles and to the nearest 5 millimeters for large cobbles and small boulders. The b-axis length was recorded in the field notes (on file at the USGS, Colorado Water Science Center, Lakewood, Colo.), and size statistics (for example, the size at the 50th percentile, or $\mathrm{d}_{50}$ ) were computed from the cumulative-frequency distribution function of sampled sediment particles.

Oblique photographs were taken from monumented locations near the channel to complement the channel survey and sediment measurements. The monumented photographs visually recorded channel features not specifically included in the surveys (for example, bank irregularities), as well as information about sediment deposits and riparian vegetation. These photographs were replicated intermittently over the duration of the study and were useful in documenting qualitative changes in the monitored reach not captured in the channel surveys or Wolman pebble counts. Cross-section plots, sediment-size distribution plots, and photographs from the Muddy Creek study site are available on the RCMAP Web site: http://co.water.usgs.gov/ projects/rcmap/MuddyCreek/indexmuddycreek.html (accessed April 28, 2010).

\section{Discharge Measurements}

Discharge measurements and water-surface elevation recordings are made routinely at USGS streamflowgaging station 09041400 Muddy Creek below Wolford Mountain Reservoir, near Kremmling, located at the upstream end of reach 1 (figs. 2 and 3). Continuously recorded data from the Muddy Creek gaging station were used to monitor daily discharge conditions in 2008 and 
to provide reference discharges for hydraulic simulations. Real-time Muddy Creek streamflow conditions are available online at: http://waterdata.usgs.gov/co/nwis/ $u v / ?$ site_no $=09041400 \&$ PARAmeter_cd $=00065,00060$ (accessed April 28, 2010).

The FaSTMECH computational streamflow model used in this analysis requires locally specific discharge and watersurface data for calibration and verification. Consequently, additional discharge measurements were made and water-surface elevations were recorded in each of the reaches over a wide range of discharges. An Argonaut acoustic Doppler velocity meter (ADVM) that recorded water-surface elevations and twodimensional velocity fields was installed in each reach (Stevens and others, 2008). In reach 1, an ADVM was installed approximately $10 \mathrm{~m}$ downstream from cross section 2, approximately $150 \mathrm{~m}$ downstream from streamflow-gaging station 09041400 (fig. 3). In reach 2, an ADVM was installed approximately $11 \mathrm{~m}$ upstream from cross section 12 (fig. 4). These instruments continuously recorded velocities and water-surface elevations from April 30, 2008, through August 1, 2008, a period that included late-winter base flow, a rapid spring rise to the annual peak discharge, and a gradual decrease to late-summer base flow, all controlled by releases from the reservoir.

Discharges were computed from velocities measured near the ADVM locations several times in each reach with a Teledyne RD Instruments StreamPro acoustic Doppler current profiler (ADCP) mounted on a small float and tethered across the channel (Simpson, 2001; Gotvald and Oberg, 2008). Graphical output of velocities determined from an ADCP measurement are shown in figure 7. The velocities measured with the ADVM and ADCP for a specific discharge were highly correlated $\left(\mathrm{R}^{2}=0.98\right)$. Discharges of $949,762,687$, 397,153 , and $71 \mathrm{ft}^{3} / \mathrm{s}$ were computed from ADCP measurements in reach 1 and 1,010, 744, 392, 76, and $28 \mathrm{ft}^{3} / \mathrm{s}$ in reach 2 . The ADCP discharges were paired with concurrently recorded ADVM water-surface elevations to develop stage/ discharge rating relations for the two reaches and to validate using discharges continuously recorded at streamflow-gaging station 09041400 as an input condition for the FaSTMECH model simulations.

Discharge measured with the ADCP on the day of the 2008 annual peak was 2 percent higher in reaches 1 and 5 percent higher in reach 2 than the instantaneous discharges recorded concurrently at the USGS streamflow-gaging station (935 and $964 \mathrm{ft}^{3} / \mathrm{s}$, respectively). These differences did not account for traveltime from the USGS gage to the ADCP measurement locations, but they were within the measurement margin of error, indicating no substantial discharge gain or loss in the two reaches at high flow. However, for discharges recorded at the gaging station in the 690 - to $700-\mathrm{ft}^{3} / \mathrm{s}$ range, discharge measured at the reach $1 \mathrm{ADCP}$ site was 11 percent higher and discharge measured at the reach $2 \mathrm{ADCP}$ site was 7 percent higher than discharge at the gaging station. The ADCP differences in reaches 1 and 2 increased to 16 and 14 percent greater than, respectively, discharge recorded at the gaging station for discharges of $343 \mathrm{ft}^{3} / \mathrm{s}$. The pattern of reach 1 and reach $2 \mathrm{ADCP}$ discharge measurements being greater than discharges recorded concurrently at the gaging station might indicate some groundwater or surface-water addition between the gaging station at the upstream end of reach 1 and the two ADCP measurement sites downstream (fig. 2, 3, and 4).

Use of the ADCP also enabled a check on the bed stability during the time of the discharge measurements. ADCP data were collected during 3- to 5-minute stationary recordings at both measurement sites and indicated that movement of streambed sediment was nonexistent or insignificant for all discharge measurements. Confirmation of a stable streambed resulted in greater confidence in the accuracy of the discharge measurements. The method of ADCP discharge measurement is described in greater detail in Simpson (2001) and Gotvald and Oberg (2008).

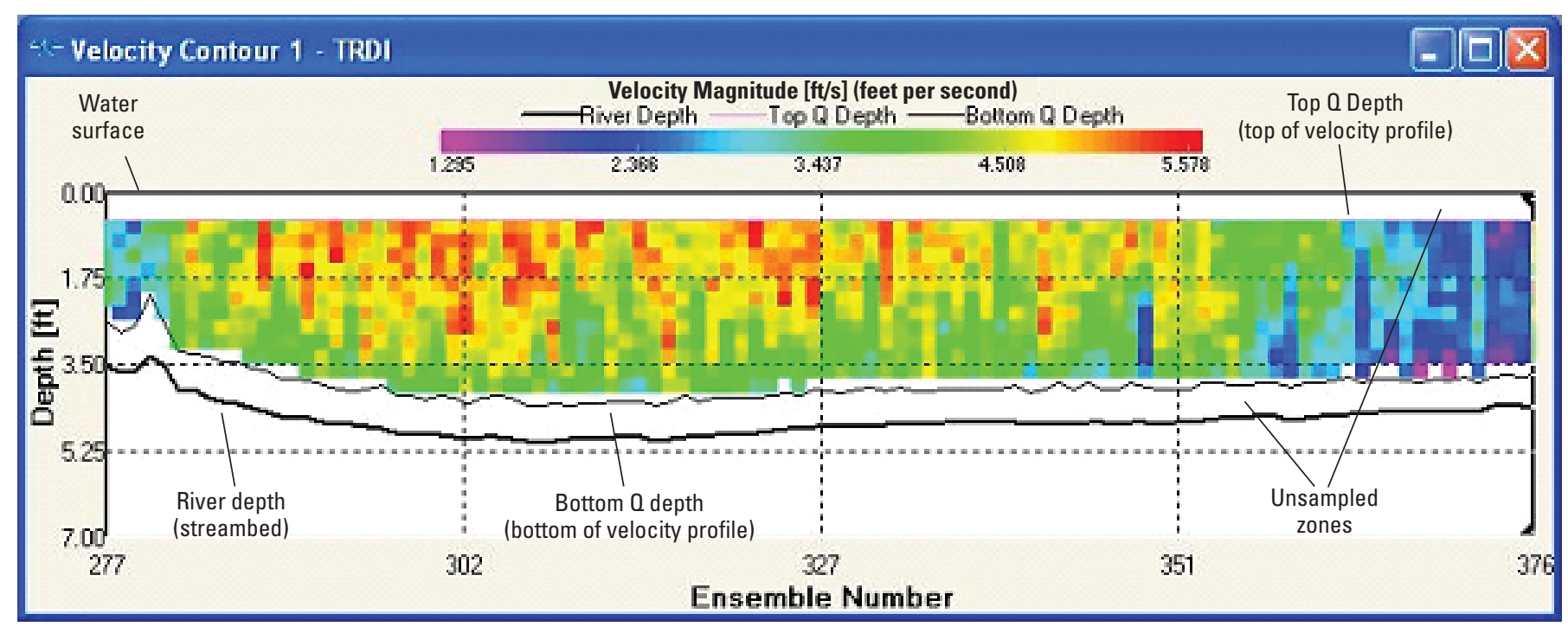

Figure 7. Graphical output from an acoustic Doppler current profiler (ADCP) discharge measurement, Muddy Creek reach 1 near cross section 2. 
Data from Hobo pressure transducers determined watersurface elevations near the downstream ends of the reach 1 and reach 2 . The pressure transducers were installed approximately $12 \mathrm{~m}$ downstream from cross section 5 in reach 1 (fig. 3 ) and approximately $39 \mathrm{~m}$ downstream from cross section 13 in reach 2 (fig. 4). The pressure-transducer derived water-surface elevations at the downstream end of the MD_SWMS computational grids were paired with concurrent discharges from the ADVM rating curves and together provided two of the necessary boundary conditions for FaSTMECH model calibration, those being the upstream discharge and the downstream watersurface elevation.

\section{Multidimensional Hydraulic Modeling}

Multidimensional streamflow models can be used to determine spatially distributed hydraulic variables, for example, velocity, depth, water-surface elevation, and bed shear stress. Applications include flood-inundation prediction, floodhydraulics reconstruction, habitat analysis, and estimation of erosion potential, sediment transport, and in-stream flow requirements. A multidimensional streamflow model was developed to reconstruct hydraulic conditions (water-surface elevation, flow depth, velocity, bed shear stress, and sedimenttransport strength) for several discharges in Muddy Creek study reaches 1 and 2. Output from the model was used to evaluate geomorphic changes observed at monumented cross sections during the monitoring period (2001-2008) and to assess the effect of selected flow-directing boulder structures on hydraulic conditions.

The USGS Multi-Dimensional Surface-Water Modeling System (MD_SWMS) was used in this study to simulate hydraulic conditions in Muddy Creek. MD_SWMS is a preand postprocessing application for computational models of surface-water hydraulics (McDonald and others, 2005b). The MD_SWMS is both a tool and framework that provide an easily used interface to a variety of environmental hydraulic models. The MD_SWMS Graphical User Interface (GUI) tool was used to build a computational grid for each Muddy Creek modeled reach, edit datasets, apply boundary conditions, run multiple discharge simulations, and view and evaluate the results (McDonald and others, 2005a).

The computational streamflow modeling program FaSTMECH, developed by the USGS (Nelson and others, 2003; McDonald and others, 2005a and 2005b), was used in MD_SWMS to simulate Muddy Creek hydraulic conditions. FaSTMECH is a steady-state, 2-dimensional, vertically averaged streamflow modeling program that includes a subroutine to calculate vertical distribution of the primary velocity and the secondary flow about the vertically averaged flow. The approach used has been shown to adequately simulate the velocity field, bed shear stress, and resulting erosion and(or) deposition patterns where secondary flows are significant (Barton and others, 2005). Basic output from FaSTMECH includes water-surface elevation, flow depth,
Froude number, velocity magnitude and direction, bed shear stress, and sediment-transport strength. FaSTMECH has been used to evaluate hydraulic conditions, sediment mobility, aquatic habitat, and flood inundation in several fluvial studies (Barton and others, 2005; Kenney, 2005; Berenbrock and Tranmer, 2008).

FaSTMECH was used to evaluate the flow depth, velocity, bed shear stress, and sediment transport strength (or entrainment potential) in Muddy Creek in the absence of (reach 1), and in the presence of (reach 2), artificial flowdirecting boulder structures in the creek. Hydraulic conditions were simulated for four discharges that represented the full range of Muddy Creek discharges from late-season low-flow conditions to out-of-bank flooding as described in the "Discharge Measurements" section. The model computed hydraulic conditions for a specific, instantaneous discharge but did not account for the duration of streamflows.

FaSTMECH requires detailed channel topography, discharge at the upstream boundary of the modeled reach, and a corresponding water-surface elevation at the downstream boundary as model input data. Topographic data can be from a variety of sources including digital elevation models (DEM), field surveys, and bathymetric data from inundated areas, but these topographic data need to be collected at a scale corresponding to the scale of the desired model results. Field surveys of the Muddy Creek streambed and flood-plain topography, discharge measurements, and water-surface-elevation recordings made in 2008 were used for model calibration in this study. Model output for each discharge was verified by the agreement between observed and predicted water-surface elevations at several locations in each reach.

Elevation data collected in the 2008 RTK GPS survey, previously described, were used to define a detailed topographic surface of the Muddy Creek streambed, banks, alluvial bars, and nearby flood plain for the streamflow model in each modeled reach. To better define the hydraulic properties near the boulder structures in reach 2 , closely spaced topographic points were surveyed where these structures could be approached safely by wading at low discharge. Sediment-size data from six locations in the two reaches were used to determine boundary roughness conditions and to assess sediment mobility under four different discharge scenarios.

The computational grid used in FaSTMECH is a curvilinear orthogonal coordinate system with a user-defined centerline that approximately followed the midchannel location of the near-to-bankfull discharge. Reach 1 and reach 2 were modeled individually and for each simulated discharge, but the same computational grid was used for each discharge within a reach. FaSTMECH model calibration data and output are in international system (SI) units.

Calibration of the model begins with referencing the topographic data to the curvilinear grid system for data interpolation and computational-grid mapping. The surveyed topographic data $(\mathrm{X}, \mathrm{Y}$, and $\mathrm{Z}$, corresponding to northing, easting, and elevation) were mapped to coordinates of the computational grid through a "nearest-neighbor" method (Barton and 
others, 2005). The model topography, as well as ancillary data such as a digital orthophoto quadrangle (DOQ) image, used the coordinate system of the RTK GPS survey (in this study, UTM Zone 13 North, horizontal datum NAD 83, vertical datum NAVD 88, Geoid 03, ellipsoid WGS 84). This series of steps interpolated and assigned elevation data to each grid cell (node) creating a seamless 0.5 - by 0.5 -meter curvilinear computation grid for each reach. These grids were then used in conjunction with the water-surface elevation data measured during the RTK GPS survey and temporary water-level gages to generate four hydraulic models representing four specific discharges in reach 1 and reach 2.

Calibration of the FaSTMECH models continued by iteratively adjusting the model parameters within reasonable limits to obtain the best fit of predicted water-surface elevations to the observed (surveyed) water-surface elevations for each simulated discharge. The model parameters were adjusted until (1) the conservation of mass was satisfied, as indicated when the root mean square error (RMSE, an aggregate measure of the differences between predicted and observed variables) of change in discharge converged on a small value and remained consistent throughout the duration of the simulation after some number of model iterations, (2) the predicted water-surface elevations closely matched the observed (surveyed) water-surface elevations corresponding to several measured discharges, and (3) the RMSE of observed and predicted water-surface elevations was minimal. Close agreement between observed and predicted water-surface elevations was considered verification of the model input parameters.

The model parameter most often adjusted was the drag coefficient. Adjustments in the drag coefficient were needed to accurately simulate head loss in the channel. Initially, a constant drag coefficient was applied to the entire streambed in each reach (reach 1 and reach 2 were modeled individually). Occasionally and when justified by onsite observations, a different drag coefficient was applied to a specific subarea of the streambed. This was done in reach 2 for the low-discharge simulation where flow-directing boulder structures created isolated zones of very large drag. A variable drag coefficient, calculated from the bed-material median particle size, was used in reach 2 for the $343 \mathrm{ft}^{3} / \mathrm{s}$ discharge.

Other model parameters (lateral eddy viscosity or the relaxation parameters) sometimes were adjusted until model output closely matched observed conditions. The lateral eddy-viscosity parameter (in $\mathrm{m}^{2} / \mathrm{s}$ ) in FaSTMECH represents the lateral momentum exchange due to turbulence or other variability that is not generated at the streambed (Nelson and others, 2003) and is computed as the product of average velocity (in meters per second) and average flow depth (in meters) times 0.01 . The relaxation parameters affect the length of time allowed for the model to converge on a numerical solution.

Output from the discharge simulations was used to evaluate the effects of low, medium, high, and out-of-bank discharges on channel hydraulic conditions (depth and flow velocity), streambed stability (bed shear stress and sedimenttransport strength), and channel geometry adjustments observed over several previous years. Discharge simulations for reach 2 also provided some perspective on the ability of the FaSTMECH model, calibrated at the half-meter resolution of this study, to simulate the hydraulic effects of flow-directing boulder structures that are commonly used in "natural-channel design" rehabilitation projects (Elliott and Capesius, 2009). FaSTMECH model solutions were created as plan-view mapped (scalar) or directional (vector) images for several variables, including the following presented in this study: depth (in meters), velocity (in meters per second), bed shear stress (in newtons per square meters), and sediment-transport strength (dimensionless).

Transport of coarse streambed sediment is necessary for long-term maintenance of channel geometry. Entrainment of coarse streambed sediment also is the mechanism for periodic flushing of fine sediment from interstitial areas between gravel and cobbles to maintain aquatic habitat quality (Milhous, 1982). The FaSTMECH transport-strength solution represented the potential for sediment entrainment and transport; however, it did not simulate the cumulative effects of streambed evolution over time. Sediment-transport strength (TS) computed in FaSTMECH is defined as:

$$
\mathrm{TS}=\left(\tau_{\mathrm{b}}-\tau_{\mathrm{c}}\right) / \tau_{\mathrm{c}}
$$

where

$\tau_{b}$ is bed shear stress, in newtons per square meter, and

$\tau_{c}$ is the critical shear stress for sediment on the streambed, in newtons per square meter (R.R. McDonald, U.S. Geological Survey, oral commun., April 8, 2009).

Sediment entrainment in alluvial channels is partly a function of the shear stress, the tangential stress component from flowing water acting on the channel boundary or on sediment particles resting on or in the streambed. The critical shear stress is considered to be the shear stress at which sediment on the streambed is at the threshold of mobility, entrainment, or transport. Sediment entrainment is anticipated when $\tau_{b}$ equals or exceeds $\tau_{c}$.

The critical shear stress has been related to sediment-size characteristics (Shields, 1936; Lane, 1955; Fahnestock, 1963; Milhous, 1982; Carling, 1983; Komar, 1987; Wiberg and Smith, 1987; Wilcock and Southard, 1988; Wilcock, 1992). The Shields (1936) equation commonly is used to estimate $\tau_{c}$ for entrainment of the streambed median sediment size, or $\mathrm{d}_{50}$ :

$$
\tau_{\mathrm{c}}=\tau_{\mathrm{c}}^{*}\left(\gamma_{\mathrm{s}}-\gamma\right) \mathrm{d}_{50}
$$

where

$\tau^{*}{ }_{\mathrm{c}}$ is the dimensionless critical shear stress, or Shields parameter;

$\gamma$ is the specific weight of water $\left(9,807 \mathrm{~N} / \mathrm{m}^{3}\right.$ at 5 degrees $\mathrm{C}$ );

$\gamma_{\mathrm{s}}$ is the specific weight of sediment (here assumed to be 2.65 times the specific weight of water);

and

$d_{50}$ is the median sediment-particle size (meters). 
Use of equation 2 requires an estimated or calculated $\tau^{*}$, a value that varies with particle size, sorting, subsurface particle size, and bed-material structure (Meyer-Peter and Muller, 1948; Neill, 1968; Parker and others, 1982; Andrews, 1983; Komar, 1987; Powell and Ashworth, 1995). FaSTMECH computes $\tau^{*}{ }_{\mathrm{c}}$ by using the method of Parker and others (2003, equation 14), which results in a $\tau^{*}$ in accord with Neill's (1968) observation of $\tau^{*}{ }_{\mathrm{c}}$ equal to 0.030 for coarse-material (gravel-bed) rivers. A $\tau^{*}{ }_{\mathrm{c}}$ equal to 0.030 was determined to be an appropriate, conservative value for many mountain streams in Colorado in a previous study where sediment-size characteristics and the conditions of sediment entrainment were quantified (Elliott and Hammack, 1999 and 2000). Consequently, this value has been used in entrainmentpotential estimates for other reconfigured gravel- and cobble-bed rivers (Elliott and Capesius, 2009).

Sediment-transport strength (TS) solutions for Muddy Creek are shown graphically in FaSTMECH for values of 0 or greater, a condition for which $\tau_{b}$ is equal to or greater than $\tau_{c}$ (eq. 1). When $\tau_{b}$ is less than $\tau_{c}$, TS is negative. FaSTMECH includes negative TS values with zero TS values in the GUI scalar representation of the model solution (R.R. McDonald, U.S. Geological Survey, oral commun., June 11, 2009). Therefore, conditions approaching, but not yet reaching, the sediment-entrainment threshold are difficult to distinguish visually in FaSTMECH graphical output.

The critical shear stress associated with sediment entrainment (eq. 2) is, at best, a minimum estimate of the critical discharge at which sediment moves and hydraulically induced channel adjustments begin, because only a small area of the entire surface or a few particles of the $d_{50}$ size might be entrained by the critical discharge (Lisle and others, 1993; Milhous, 1982). Many researchers feel that conditions for more widespread sediment mobility of a greater area of the streambed occur when $\tau_{b}$ exceeds $\tau_{c}$ by a factor of 2 or greater (Wilcock and McArdell, 1993). This is equivalent to a TS of 1 or greater (eq. 1) in FaSTMECH. Consequently, TS values of 1 or greater were considered the reference value for widespread sediment entrainment in the Muddy Creek analyses presented in this report.

\section{Geomorphic Characteristics}

The channel surveys and pebble counts made in Muddy Creek quantify the channel geometry and sedimentologic characteristics in reaches 1 and 2 during the monitoring period from 2001 through 2008. During the monitoring period, reach 2 was reconfigured by channel excavation, cut-bank angle reduction, riprap bank reinforcement (fig. 5), and construction of flowdirecting boulder structures (fig. 6). Both reaches conveyed a range of discharges that included very small annual discharge peaks and the second largest annual discharge peak since construction of the Ritschard Dam and Wolford Mountain Reservoir in 1995 (table 1).

Muddy Creek sediment-size characteristics were determined from six Wolman pebble counts in the two reaches. Sediment composing the streambed in reaches 1 and 2 was
Table 1. Annual peak discharge recorded at USGS streamflowgaging station 09041400 Muddy Creek below Wolford Mountain Reservoir near Kremmling, Colorado, water years 1996-2008.

$\left[\mathrm{ft}^{3} / \mathrm{s}\right.$, cubic feet per second; $\mathrm{m}^{3} / \mathrm{s}$, cubic meters per second; discharge affected by reservoir operation]

\begin{tabular}{clcc}
\hline $\begin{array}{c}\text { Water } \\
\text { year }\end{array}$ & \multicolumn{1}{c}{ Date } & $\begin{array}{c}\text { Peak } \\
\text { discharge } \\
\left(\mathbf{f t}^{3} / \mathbf{s}\right)\end{array}$ & $\begin{array}{c}\text { Peak } \\
\text { discharge } \\
\left(\mathbf{m}^{3} / \mathbf{s}\right)\end{array}$ \\
\hline 1996 & May 20, 1996 & 656 & 18.6 \\
1997 & June 2, 1997 & 1,030 & 29.2 \\
1998 & May 13, 1998 & 871 & 24.7 \\
1999 & June 3, 1999 & 518 & 14.7 \\
2000 & May 12, 2000 & 889 & 25.2 \\
2001 & September 11, 2001 & 231 & 6.54 \\
2002 & September 1, 2002 & 233 & 6.60 \\
2003 & October 21, 2002 & 217 & 6.14 \\
2004 & September 29, 2004 & 225 & 6.37 \\
2005 & October 1, 2004 & 221 & 6.26 \\
2006 & May 21, 2006 & 917 & 26.0 \\
2007 & May 19, 2007 & 278 & 7.87 \\
2008 & May 22, 2008 & 968 & 27.4 \\
\hline
\end{tabular}

similar in size and sorting (fig. 8). The median particle size $\left(\mathrm{d}_{50}\right)$ of the streambed sediment was determined from four pebble counts made in 2008 and ranged from 27 to $44 \mathrm{~mm}$.

Reach 2 differed from reach 1 in that finer particle-size alluvial point bars were exposed at low discharges in some areas of reach 2. Two point bars were sampled in reach 2; one point-bar pebble count was made October 31, 2003, and the other was made in July 2008, 5 years after reconfiguration in reach 2 . The point bar at cross section 10, sampled in 2003 (fig. 8) $\left(\mathrm{d}_{50}=16 \mathrm{~mm}\right.$ ), was poorly sorted and was composed of 18 percent sand-sized material or finer (particle sizes smaller than or equal to $2 \mathrm{~mm}$ in diameter), possibly reflecting the disturbed condition of Muddy Creek immediately following channel reconfiguration in the autumn of 2003. By 2008 , sediment on the comparable, nearby point bar at cross section $12\left(\mathrm{~d}_{50}=9 \mathrm{~mm}\right)$ was better sorted and was composed of only 5 percent sand-size material or finer (fig. 8). The average $\mathrm{d}_{50}$ of all six streambed and point-bar samples was $29 \mathrm{~mm}$.

Channel cross-section dimensions in reach 1 , the control reach, changed little during the monitoring period (figs. 9 and 10), including cross sections 3 and 4 in a very sinuous area (fig. 3 ). Muddy Creek flows adjacent to the distal margin of an incised alluvial fan and has created a vertical scarp on the east (left) bank between cross sections 4 and 5 (figs. 2 and 3). However, less than $1 \mathrm{~m}$ of lateral erosion occurred here between 2001 and 2008. The greatest change in reach 1 was at cross section 6 where lateral erosion between 2001 and 2008 resulted in $2.5 \mathrm{~m}$ of concavebank retreat in a meander bend (cross section not shown). All reach 1 replicate channel cross sections from surveys made from 2001 to 2008 can be viewed online at: http://co.water.usgs.gov/ projects/rcmap/MuddyCreek/indexmuddycreek.html (accessed April 28, 2010).

Reach 2 channel reconfiguration in 2003 resulted in channel changes at many monitored cross sections that are visible by comparing surveys made in 2001 and 2003 (figs. 11 and 12). The channel was deepened by excavation, bank-top angles were decreased by grading, and in some locations, riprap boulders were 


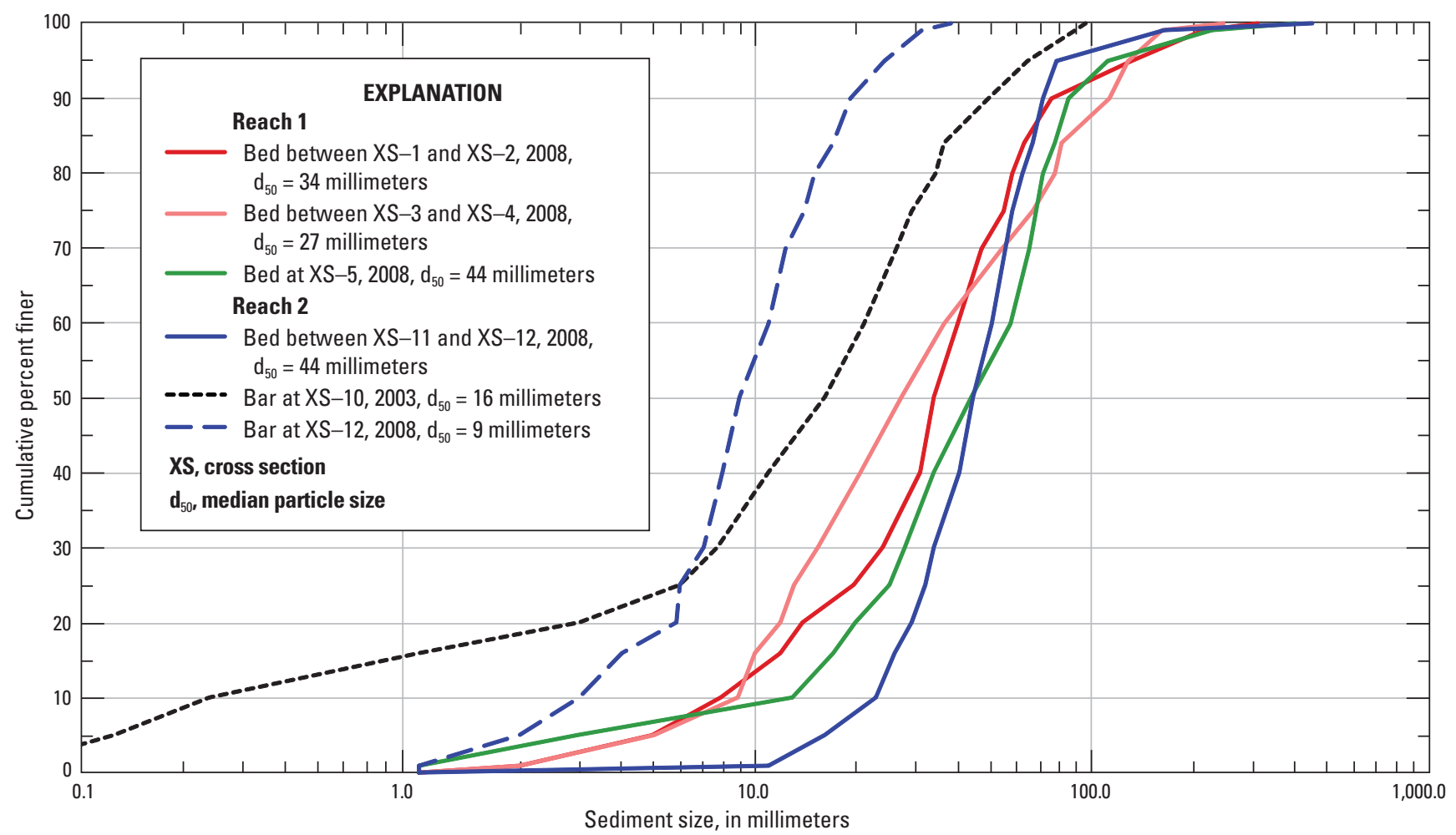

Figure 8. Cumulative sediment-size distributions from Muddy Creek.

installed to protect the outside bank of meander bends from lateral erosion (fig. 5). Numerous boulder structures were constructed to redirect streamflow lines toward mid-channel and to create bedscouring conditions at certain discharges (fig. 6).

Most cross sections in reach 2 changed very little after reconfiguration in 2003 with the exception of areas of local sediment deposition. The streambed at cross section 9 aggraded slightly after 2003 reconfiguration and, in 2008, was close to the 2001 streambed elevation (fig. 11). Alluvial bars composed of fine gravel developed in some areas of reach 2 , such as at cross sections 10 and 12 (fig. 12). Similar to cross-section 6 in reach 1, lateral erosion of the meander bend at cross section 15 resulted in $1.2 \mathrm{~m}$ of concave-bank retreat (cross-section not shown). Unlike most meander banks in reach 2 , the outer, concave bank at cross section 15 was not protected with riprap in 2003. By contrast, other reach 2 meander bends with riprap did not have changes in concave-bank location. All channel cross sections from reach 2 surveys made from 2001 to 2008 can be viewed online at: http://co.water.usgs.gov/projects/rcmap/MuddyCreek/ indexmuddycreek.html (accessed April 28, 2010).

\section{Simulation of Hydraulic Conditions}

Computational models were developed using FaSTMECH to evaluate hydraulic conditions and sediment mobility in Muddy Creek reaches 1 (control reach) and 2 (reconfigured reach) under low-, medium-, high-, and out-of-bank discharge scenarios. Hydraulic conditions were simulated for discharges of $40,345,697$, and $928 \mathrm{ft}^{3} / \mathrm{s}$ in reach 1 , and for discharges of 44, 343, 697, and $968 \mathrm{ft}^{3} / \mathrm{s}$ in reach 2 .
The channel lengths to be modeled were shorter than the monitored channel lengths (figs. 3 and 4) in both reach 1 and 2 to decrease hydraulic complexity and the potential for model instability at the upstream and downstream channel areas of the model. The reach 1 computational grid was $370 \mathrm{~m}$ long and $40 \mathrm{~m}$ wide, consisting of 58,401 nodes, or grid intersects where computations were performed. The reach 2 grid was $345 \mathrm{~m}$ long and $60 \mathrm{~m}$ wide, consisting of 82,401 computational nodes. The computational grid-cell size in each reach was approximately 0.5 by $0.5 \mathrm{~m}$.

The streamflow models were calibrated iteratively by adjusting input parameters within reasonable limits until the best match was obtained between predicted and observed (surveyed) water-surface elevations for each simulated discharge. Streamflow-model boundary conditions and input parameters from the best solutions are summarized in table 2 .

\section{Reach 1}

Measured and predicted water-surface elevations from the discharge simulations of reach 1 are shown in longitudinal profile view in figure 13. Verification (agreement between measured and predicted elevations) for each discharge simulation is summarized numerically as the water-surface elevation root mean square error (RMSE) in table 2.

The $40-\mathrm{ft}^{3} / \mathrm{s}$ discharge simulation for reach 1 had the largest water-surface-elevation dataset because the measured points were surveyed elevations of the actual water surface. Water-surface data for the other three discharges were limited to surveyed elevations of colored flagging previously placed during earlier 


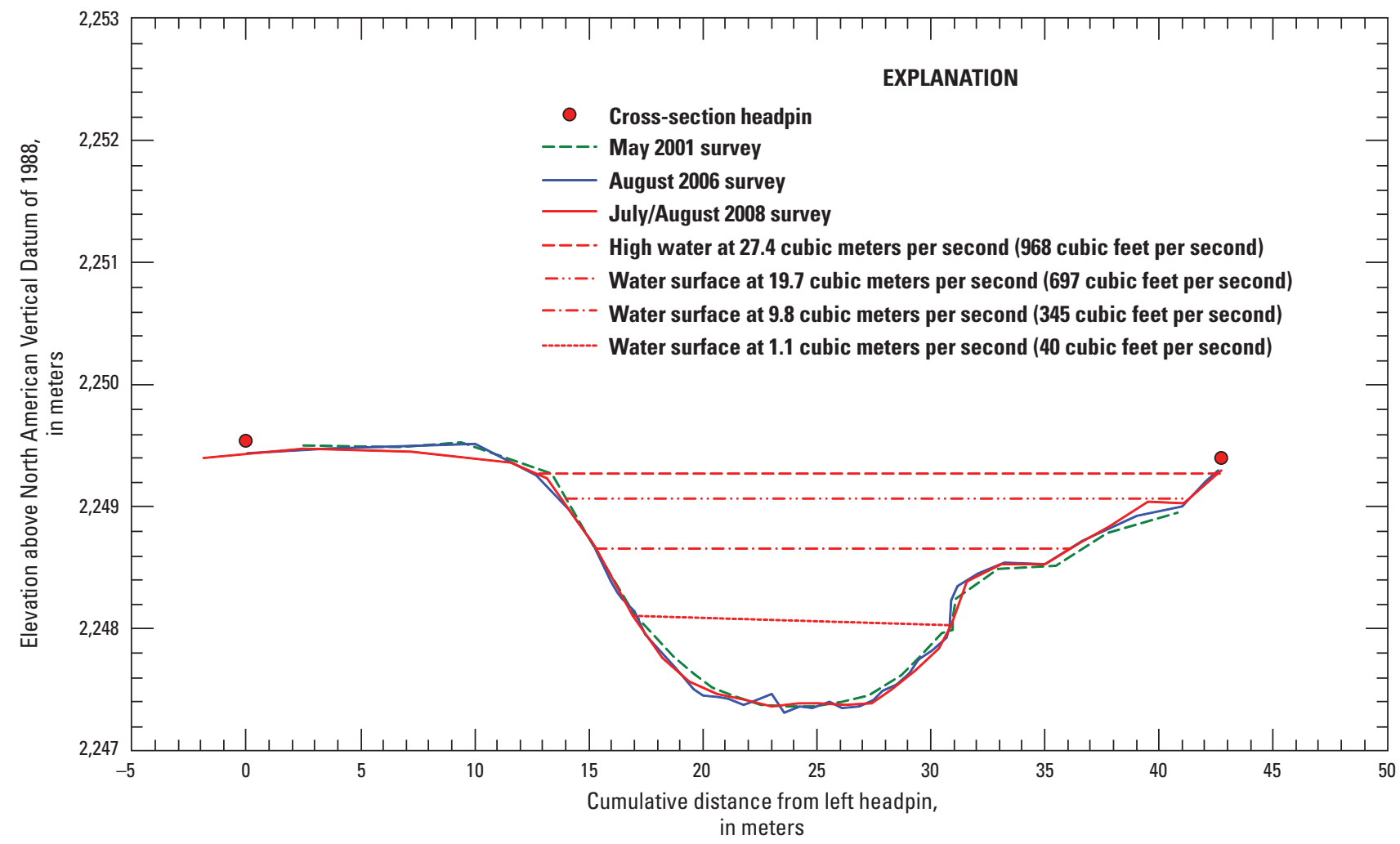

Figure 9. Plot of Muddy Creek cross section 1 downstream from Wolford Mountain Reservoir.

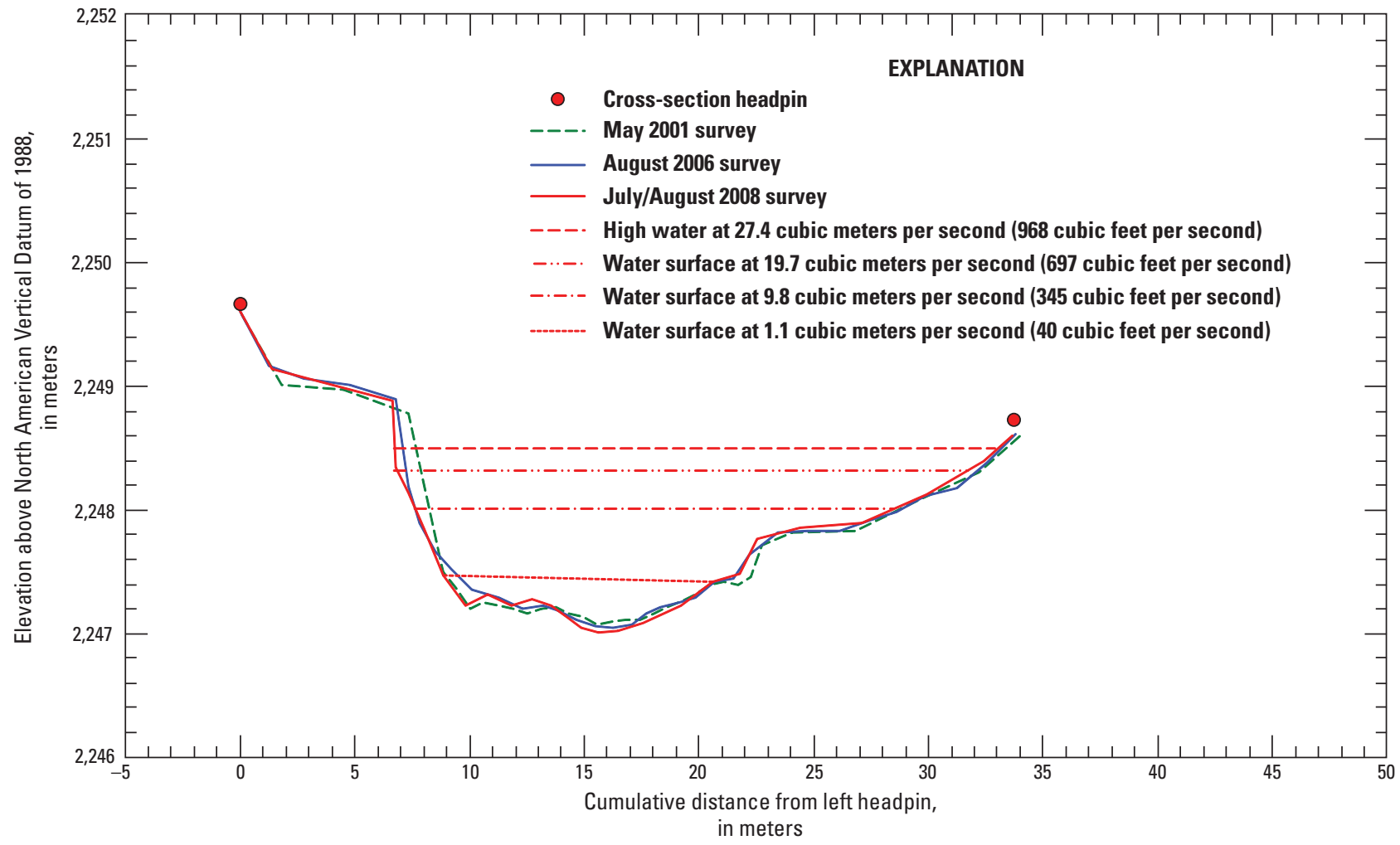

Figure 10. Plot of Muddy Creek cross section 5 downstream from Wolford Mountain Reservoir. 


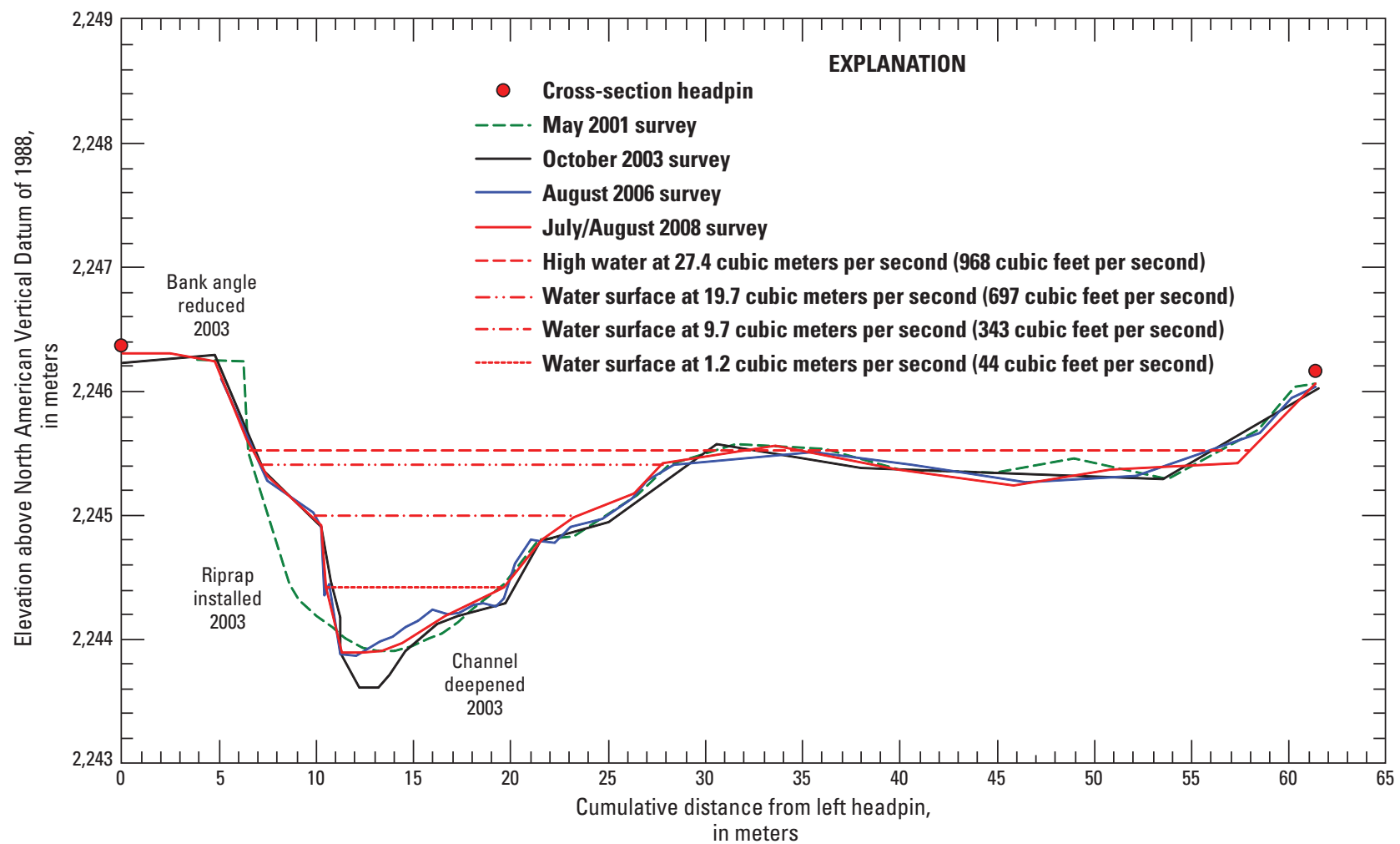

Figure 11. Plot of Muddy Creek cross section 9 downstream from Wolford Mountain Reservoir.

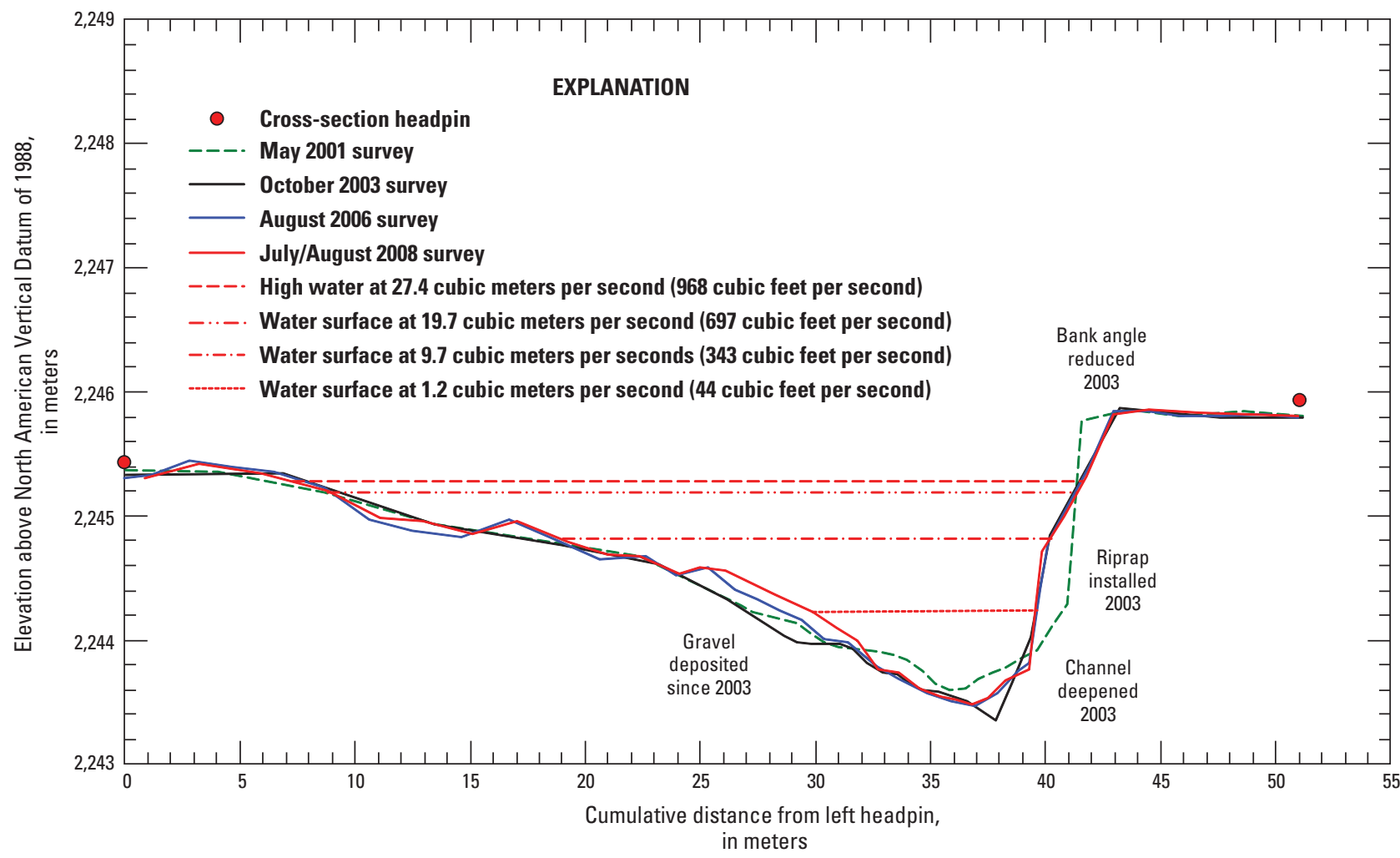

Figure 12. Plot of Muddy Creek cross section 12 downstream from Wolford Mountain Reservoir. 


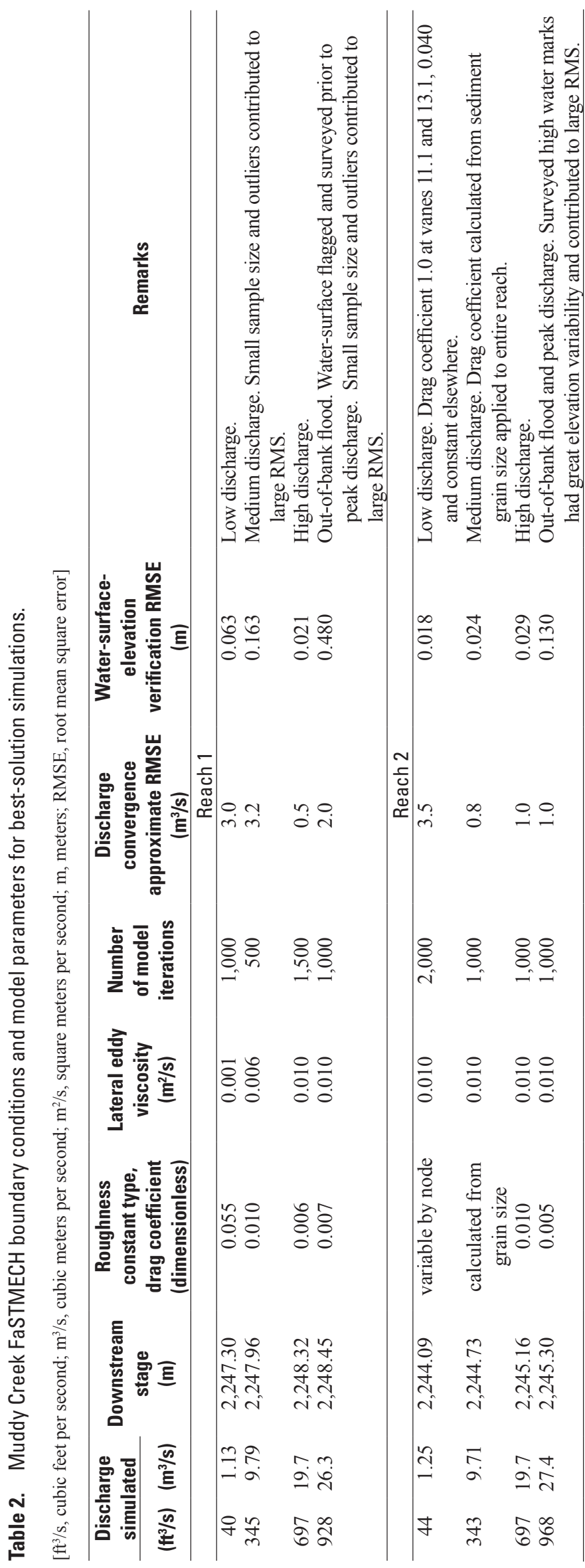




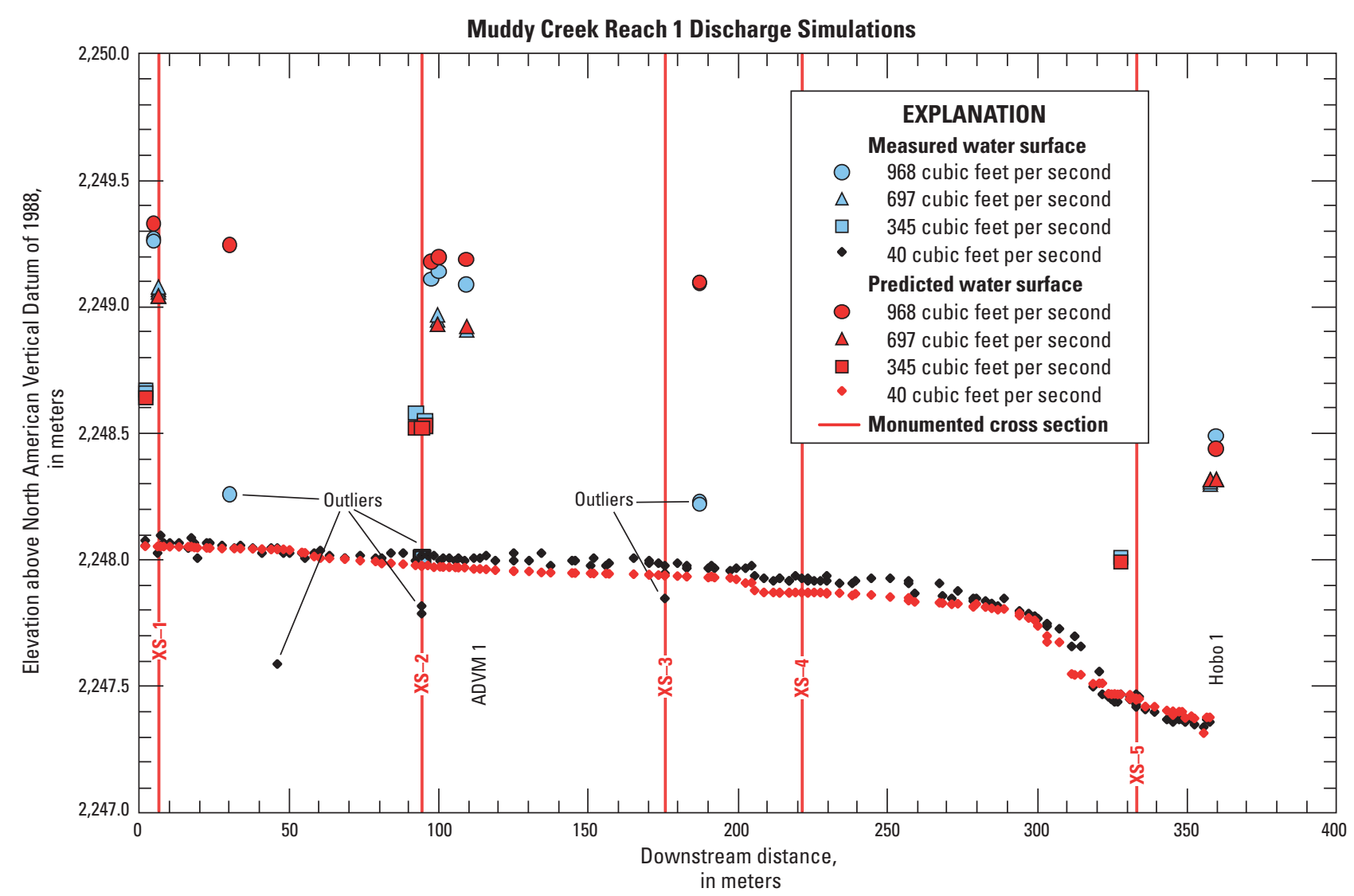

Figure 13. Longitudinal profile of measured and predicted water-surface elevations from Muddy Creek reach 1, 40, 345, 697, and 928 cubic feet per second.

site visits. Predicted water-surface elevations for $40 \mathrm{ft}^{3} / \mathrm{s}$ matched measured (surveyed) water-surface elevations reasonably well but were slightly lower than measured elevations in midreach from near cross section 2 to downstream from cross section 4 (fig. 13). The water-surface-elevation RMSE was $0.063 \mathrm{~m}$ for the $40-\mathrm{ft}^{3} / \mathrm{s}$ discharge simulation, indicating that predicted water-surface elevations were within $63 \mathrm{~mm}$ of measured elevations overall (table 2), and comparable to the scatter in measured water-surface elevations in some locations (fig. 13).

The $345-\mathrm{ft}^{3} / \mathrm{s}$ discharge simulation had a high RMSE $(0.163 \mathrm{~m})$ due to the effect of a single outlier at cross section 2 (fig. 13). This single "measured" point plots with measured $40 \mathrm{ft}^{3} / \mathrm{s}$ points and could be an outlier due to an erroneous survey code, or the flagging may have been vandalized. The other predicted points closely match the measured points; therefore, this simulation was considered to be acceptable for subsequent hydraulic interpretation. Predicted water-surface elevations from the $697-\mathrm{ft}^{3} / \mathrm{s}$ discharge simulation in reach 1 closely matched measured (surveyed) water-surface elevations (fig. 13). The RMSE for this simulation was $0.021 \mathrm{~m}$ (table 2); consequently, this simulation was considered to be acceptable for subsequent hydraulic interpretation.

The $928-\mathrm{ft}^{3} / \mathrm{s}$ discharge simulation had the highest $\operatorname{RMSE}(0.480 \mathrm{~m})$ of the four reach 1 simulations largely due to the effect of three apparent outlier points, one downstream from cross section 1 and two near cross section 3 (fig. 13). These three flagged points were approximately $1 \mathrm{~m}$ lower than nearby water-surface elevation points flagged at the same discharge and may have been vandalized or unintentionally moved between the dates of flagging (June 18, 2008) and survey (July 31, 2008). Other predicted water-surface elevations match measured elevations reasonably well; consequently, the $928-\mathrm{ft}^{3} / \mathrm{s}$ discharge simulation was considered to be acceptable for subsequent hydraulic interpretation.

FaSTMECH model solutions, or computed values, are presented as graphic images for each reach 1 discharge simulation and for each of four parameters: depth (figs. 14A-D), velocity (figs. 15A-D), bed shear stress (figs. 16A-D), and sedimenttransport strength (figs. $17 A-D$ ). Discharge at $928 \mathrm{ft}^{3} / \mathrm{s}$ is contained within the channel throughout most of reach 1 (figs. 9 and $10)$, but spreads onto lower-elevation point-bar areas as shown in figure $14 D$.

Computed depths at all simulated discharges were greatest in the upper part of reach 1 and in the sinuous, meandering middle part (figs. $14 A-D$ ). Maximum depths in reach 1 were greater than $2 \mathrm{~m}$ at $928 \mathrm{ft}^{3} / \mathrm{s}$ (fig. 14D). Maximum computed velocities in reach 1 ranged from approximately $0.6 \mathrm{~m} / \mathrm{s}$ at $40 \mathrm{ft}^{3} / \mathrm{s}, 1.6 \mathrm{~m} / \mathrm{s}$ at $345 \mathrm{ft}^{3} / \mathrm{s}$, and $2.5 \mathrm{~m} / \mathrm{s}$ at $697 \mathrm{ft}^{3} / \mathrm{s}$ (figs. $15 A, B, C$ ). The greatest maximum velocities were equal to or greater than $2.8 \mathrm{~m} / \mathrm{s}$ at $928 \mathrm{ft}^{3} / \mathrm{s}$ in the channel just downstream from the meandering area (fig. 15D) and where the channel gradient increased near cross section 5 (fig. 13). Areas of high computed bed shear stress for each discharge simulation (figs. 16A-D) generally followed the same distribution pattern as areas of high velocity. 
Computed sediment-transport strength (TS) in reach 1 generally was less than 1 (the threshold of widespread entrainment of the $d_{50}$ sediment particle size) for simulated discharges less than $697 \mathrm{ft}^{3} / \mathrm{s}$. For the $697 \mathrm{ft}^{3} / \mathrm{s}$ discharge simulation, TS reached a value of 1 in a small area just downstream from the meandering area of reach 1 (fig. 17C). For the $928 \mathrm{ft}^{3} / \mathrm{s}$ discharge simulation, the area of widespread sediment mobility where TS was equal to or greater than 1 increased to include most of the midchannel area downstream from the meanders (fig. 17D).

\section{Reach 2}

Measured and predicted water-surface elevations from the discharge simulations of reach 2 are shown in longitudinal profile view in figure 18. Verification (agreement between measured and predicted elevations) for each discharge simulation is summarized numerically as the water-surface elevation root mean square error (RMSE) in table 2.

As with the low-discharge simulation in reach 1 , the $44-\mathrm{ft}^{3} / \mathrm{s}$ discharge simulation in reach 2 had the largest water-surface elevation dataset because the measured points were surveyed elevations of the actual water surface. Water-surface data for the other three discharges were limited to surveyed elevations of colored flagging (previously placed during earlier site visits) and surveyed high-water marks. Predicted water-surface elevations for $44 \mathrm{ft}^{3} / \mathrm{s}$ matched measured (surveyed) water-surface elevations very well (fig. 18), given that the water-surface-elevation RMSE was $0.018 \mathrm{~m}$, indicating that predicted water-surface elevations were within $18 \mathrm{~mm}$ of measured elevations overall.

Predicted water-surface elevations from the 343- and $697-\mathrm{ft}^{3} / \mathrm{s}$ discharge simulations in reach 2 also closely matched measured (surveyed) water-surface elevations (fig. 18). The RMSE for these two simulations were $0.024 \mathrm{~m}$ and $0.029 \mathrm{~m}$, respectively (table 2); consequently, these simulations were considered to be acceptable for subsequent hydraulic interpretations.

The $968-\mathrm{ft}^{3} / \mathrm{s}$ discharge simulation represented the 2008 annual peak discharge and had the highest RMSE $(0.130 \mathrm{~m})$ of the four reach 2 simulations (table 2). Water-surface elevations used in this simulation were derived from post peak-discharge surveys of numerous high-water marks (HWM) that consisted of either organic flotsam (such as twigs and grass) or slack-water sediment deposits (silt or sand) (Benson and Dalrymple, 1967). These HWMs varied in elevation (fig. 18) because they were subjectively identified in the field. Another potential source of variability was flotsam deposited at different elevations by discharges at or slightly below the actual instantaneous $968-\mathrm{ft}^{3} / \mathrm{s}$ peak discharge; for example, at recessional water surfaces. The predicted water-surface elevations generally were near the upper limit of surveyed HWMs, except downstream from cross section 12 where the predicted water-surface elevations were slightly higher than the surveyed HWMs (fig. 18).

FaSTMECH model solutions are presented as graphic images for each reach 2 discharge simulation and for each of four computed parameters: depth (figs. $19 A-D$ ), velocity (figs. 20A-D), bed shear stress (figs. 21A-D), and sedimenttransport strength (figs. 22A-D). Unlike reach 1, where the $697-$ and $928-\mathrm{ft}^{3} / \mathrm{s}$ discharges were largely contained in the channel, the 697- and $968-\mathrm{ft}^{3} / \mathrm{s}$ discharges in reach 2 extend beyond the main channel onto point bars and lower areas of the adjacent valley floor (blue areas in figs. $19 C$ and $D$ ) in some locations.

Computed depths at all simulated discharges were greatest near the concave banks of meander bends in reach 2 (fig. 19). Depths for the $968 \mathrm{ft}^{3} / \mathrm{s}$ simulation were greater than $2 \mathrm{~m}$ in many areas of reach 2 and exceeded $2.5 \mathrm{~m}$ in the meander bend near the downstream end of the modeled reach (fig. 19D). Maximum computed velocities in reach 2 ranged from approximately $0.6 \mathrm{~m} / \mathrm{s}$ at $44 \mathrm{ft}^{3} / \mathrm{s}, 1.6 \mathrm{~m} / \mathrm{s}$ at $343 \mathrm{ft}^{3} / \mathrm{s}$, and $1.8 \mathrm{~m} / \mathrm{s}$ at $697 \mathrm{ft}^{3} / \mathrm{s}$ (figs. $20 A-C$ ). Maximum computed velocities only approached or exceeded $2 \mathrm{~m} / \mathrm{s}$ in the upstreammost area of reach 2 when discharge was $968 \mathrm{ft}^{3} / \mathrm{s}$ (fig. 20D). This area corresponded to the steepest channel gradient in reach 2, located upstream from cross section 9 (fig. 18). As in reach 1 , areas of high computed bed shear stress in reach 2 (figs. 21A-D) generally followed the same distribution pattern as areas of high velocity. The notable exceptions were the locally high bed shear stresses at 44 and $343 \mathrm{ft}^{3} / \mathrm{s}$ created by the boulder structures (figs. 4, 6, 21A, and 21B). The effects of some of these boulder structures on local bed shear stress appear to be diminished at higher discharges (figs. $21 C$ and $21 D$ ) because they are less effective at greater flow depths.

Computed sediment-transport strength (TS) in reach 2 predominantly was less than 1 (the threshold of widespread entrainment of the $\mathrm{d}_{50}$ sediment particle size) for simulated discharges less than $968 \mathrm{ft}^{3} / \mathrm{s}$. For the $968 \mathrm{ft}^{3} / \mathrm{s}$ discharge simulation, TS greater than 1 occurred only at a limited area in the upstream most area of reach 2 . The very high TS values, visible as small red areas on the flood plain in figure $21 D$, are anomalous results from the model, where depths were shallow, and where computed velocities were unrealistically great. Another area of very high TS occurred in the $44 \mathrm{ft}^{3} / \mathrm{s}$ discharge simulation and was located at a boulder cross vane (fig. 22A). The TS value greater than 2 at this location (red color) indicates that the median-size bed-material particles are easily transported over the boulder structure, a condition supported by field inspection (fig. 6).

Flow-directing boulder structures, such as the cross vanes commonly used in the "natural-channel design" approach (fig. 6), were surveyed and incorporated in the FaSTMECH reach 2 model topography (fig. 4). The effect of one such boulder structure is illustrated in a series of discharge simulations that display water depth (as a color-contoured area) and streamflow lines (as velocity vectors with arrow heads) (figs. $23 A-D$ ). At $44 \mathrm{ft}^{3} / \mathrm{s}$, streamflow lines converge downstream from the V-shaped area of the cross vane in the deeper (green) area of the channel, and a weak, upstream-flowing eddy is visible near the right bank where the short vectors point laterally and upstream (fig. 23A). At $343 \mathrm{ft}^{3} / \mathrm{s}$, the streamflow lines converge at the cross vane and the velocity increases as indicated by the proportionally longer vectors. The weak eddy is still present near the right bank where the cross vane is attached. At 697 and $968 \mathrm{ft}^{3} / \mathrm{s}$, the cross vane has little or no effect on streamflow-line convergence (vectors are mostly parallel). The cross vane, however, still has an accelerating effect on velocity that is propagated some distance downstream, as indicated by the midchannel vector lengths, and the eddy near the right bank still exists. 
A AllQsModeled 1.ed.riv - MD sWMS

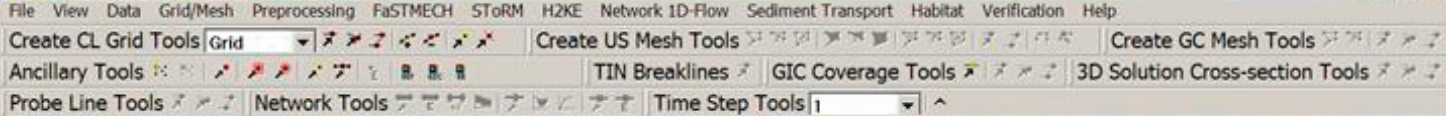

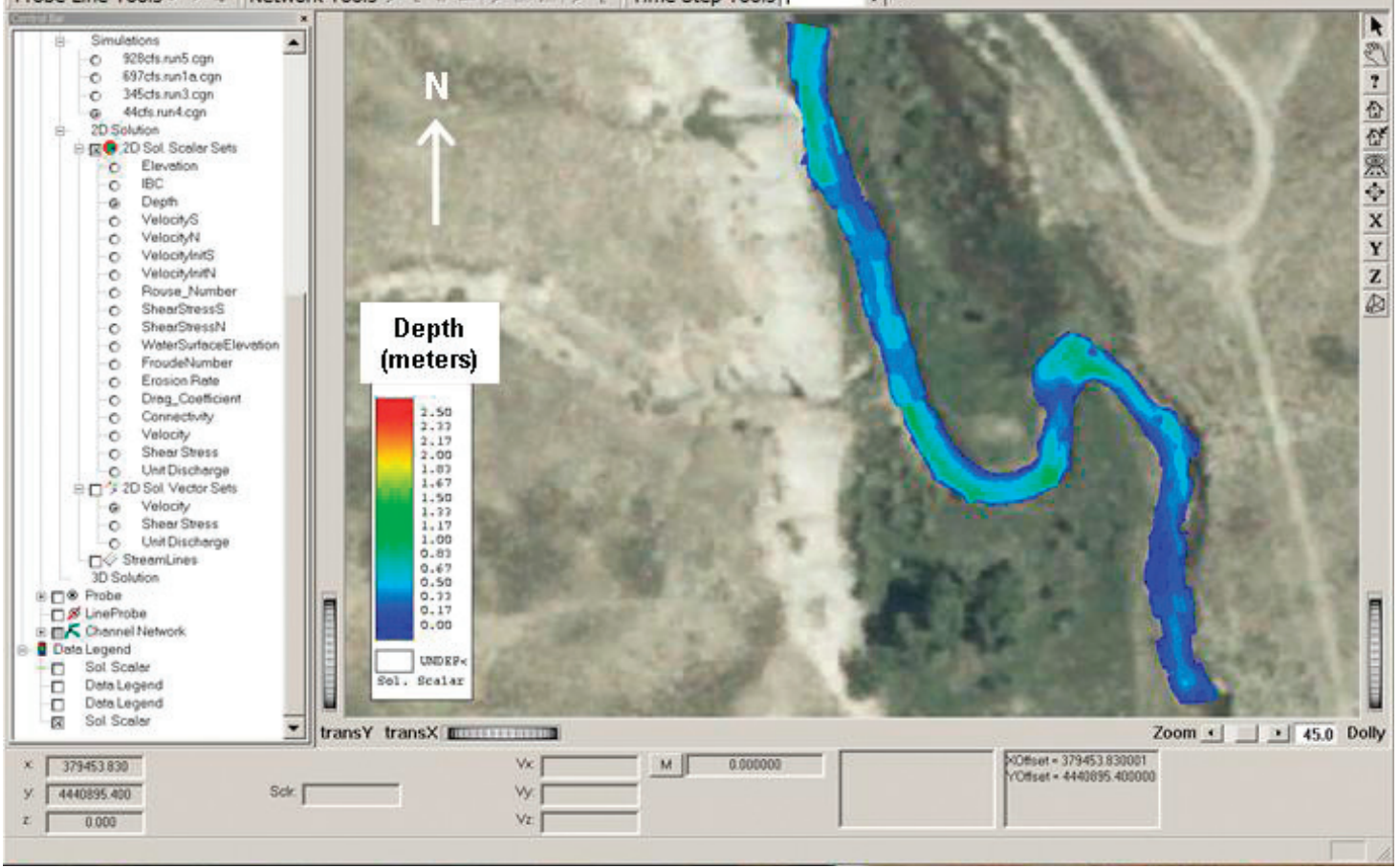

AllQsModeled1.ed.riv - MD SWMS

FSTMEOH STORM H2KE Network 1D-Fow Sediment Transport Habitat Verification Help

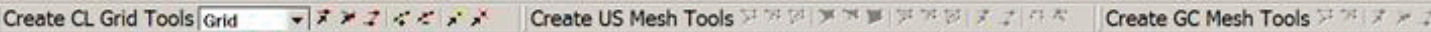

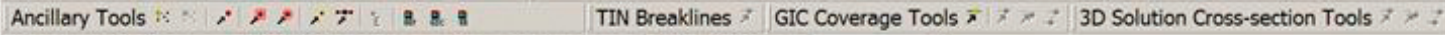

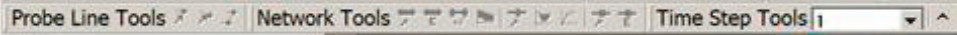

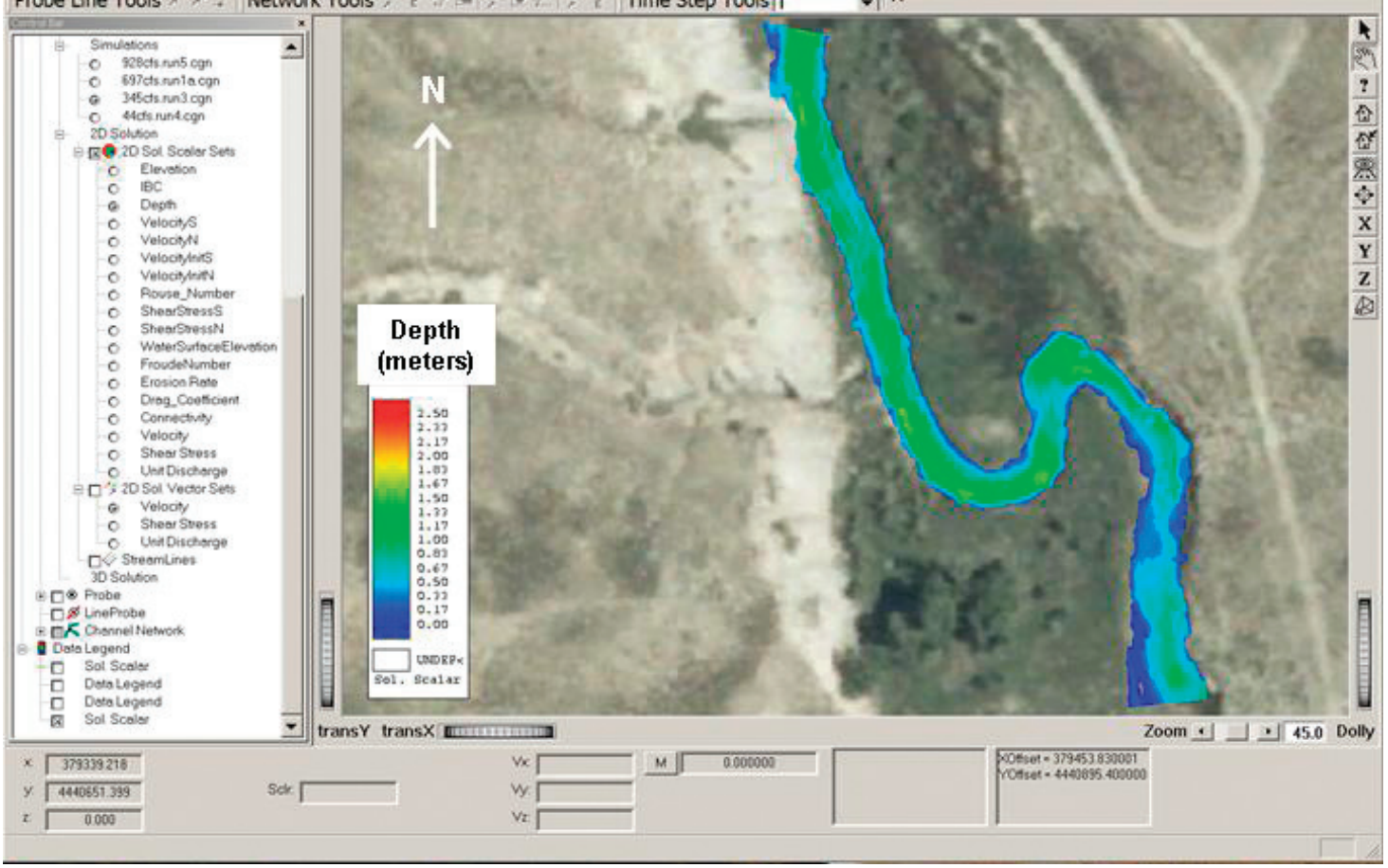

Figure 14. Muddy Creek Reach 1 FaSTMECH model solutions for depth with discharge of $(A) 1.13$ cubic meters per second (40 cubic feet per second), $(B) 9.77$ cubic meters per second (345 cubic feet per second), (C) 19.7 cubic meters per second (697 cubic feet per second), and (D) 26.3 cubic meters per second (928 cubic feet per second). 
C AllQsModeled1.ed.riv - MD_sWMS

File View Data Grid/Mesh Preprocessing FaSTMECH STORM H2KE Network 1D-flow Sediment Transport Habitat Verification Help

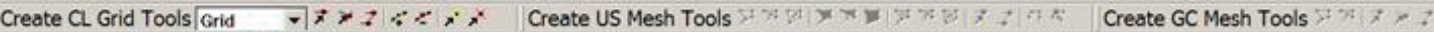

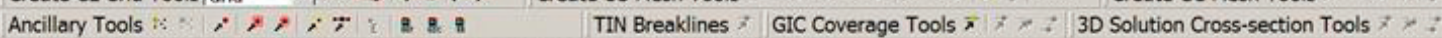

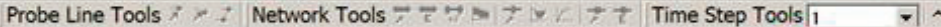

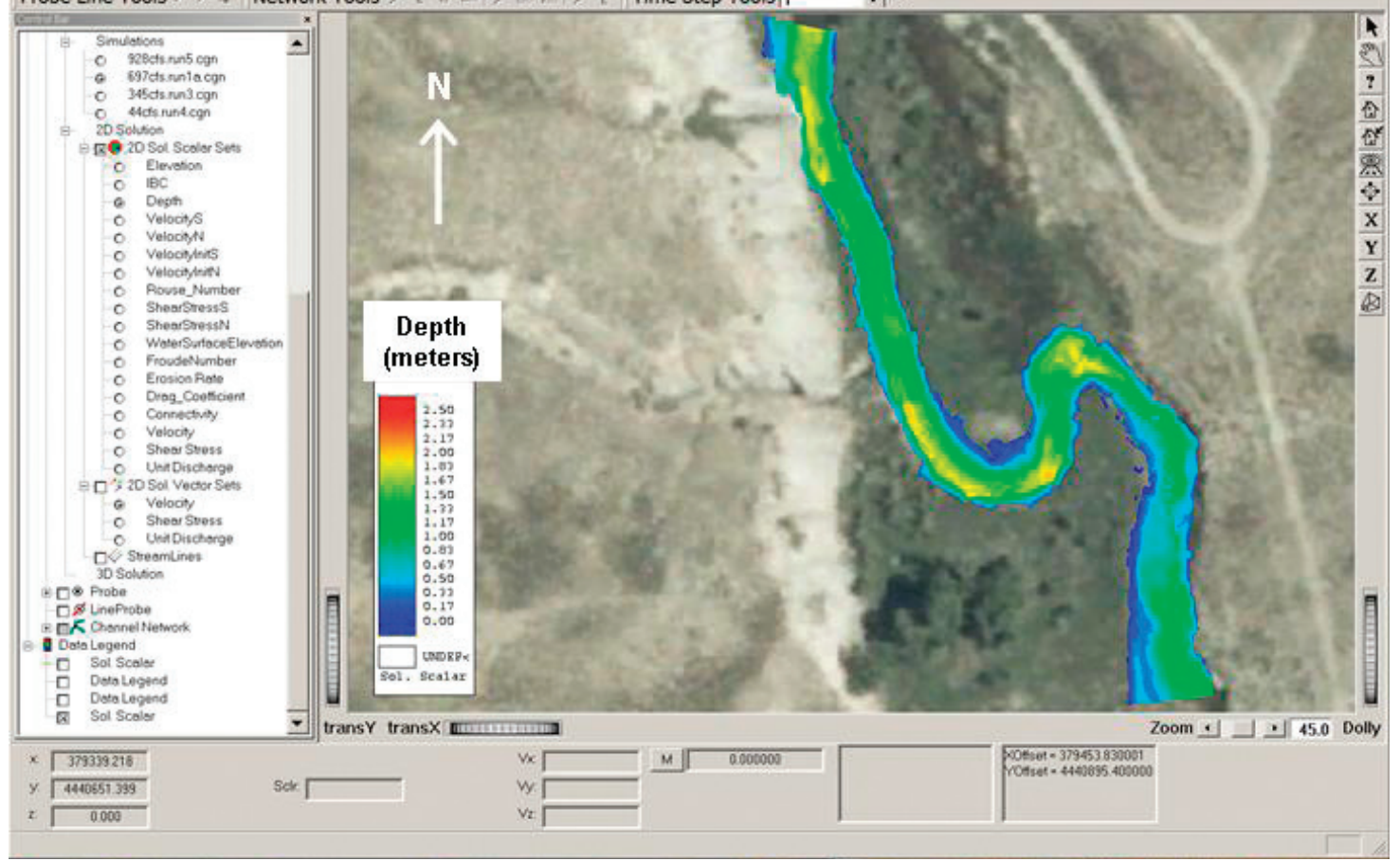

D AllOsModeled1.ed.riv - MD_SWMS

File View Data Grid/Mesh Preprocessing FaSTMEOH SToRM H2KE Network 1D-Flow Sediment Transport Habitat Veriflcation Help

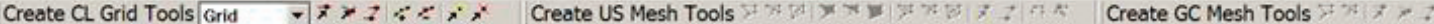

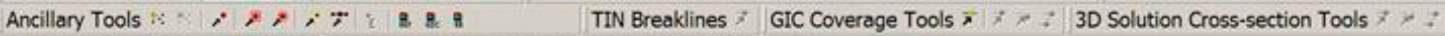

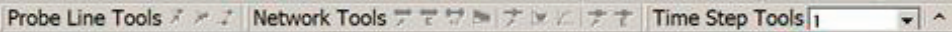

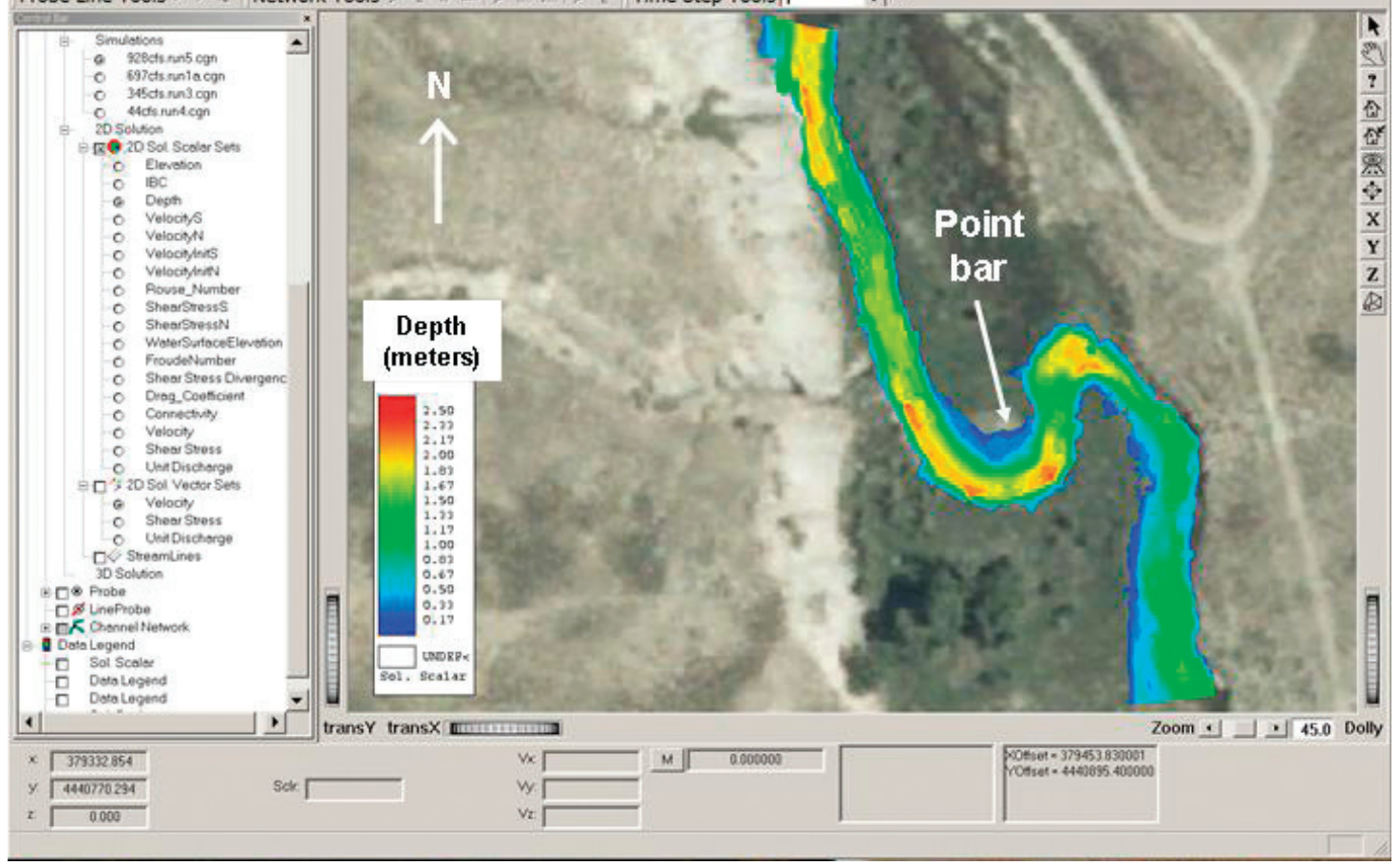

Figure 14-Continued. Muddy Creek Reach 1 FaSTMECH model solutions for depth with discharge of (A) 1.13 cubic meters per second ( 40 cubic feet per second), (B) 9.77 cubic meters per second ( 345 cubic feet per second), (C) 19.7 cubic meters per second (697 cubic feet per second), and (D) 26.3 cubic meters per second (928 cubic feet per second). 
A AllOsModeled1.ed.riv - MD_sWMS

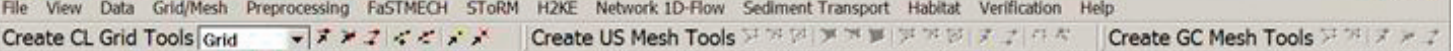

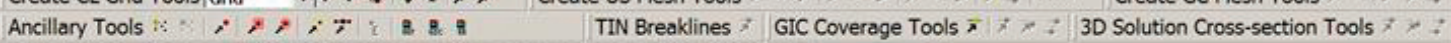

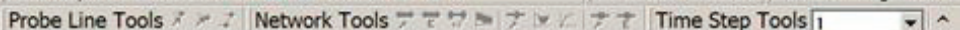

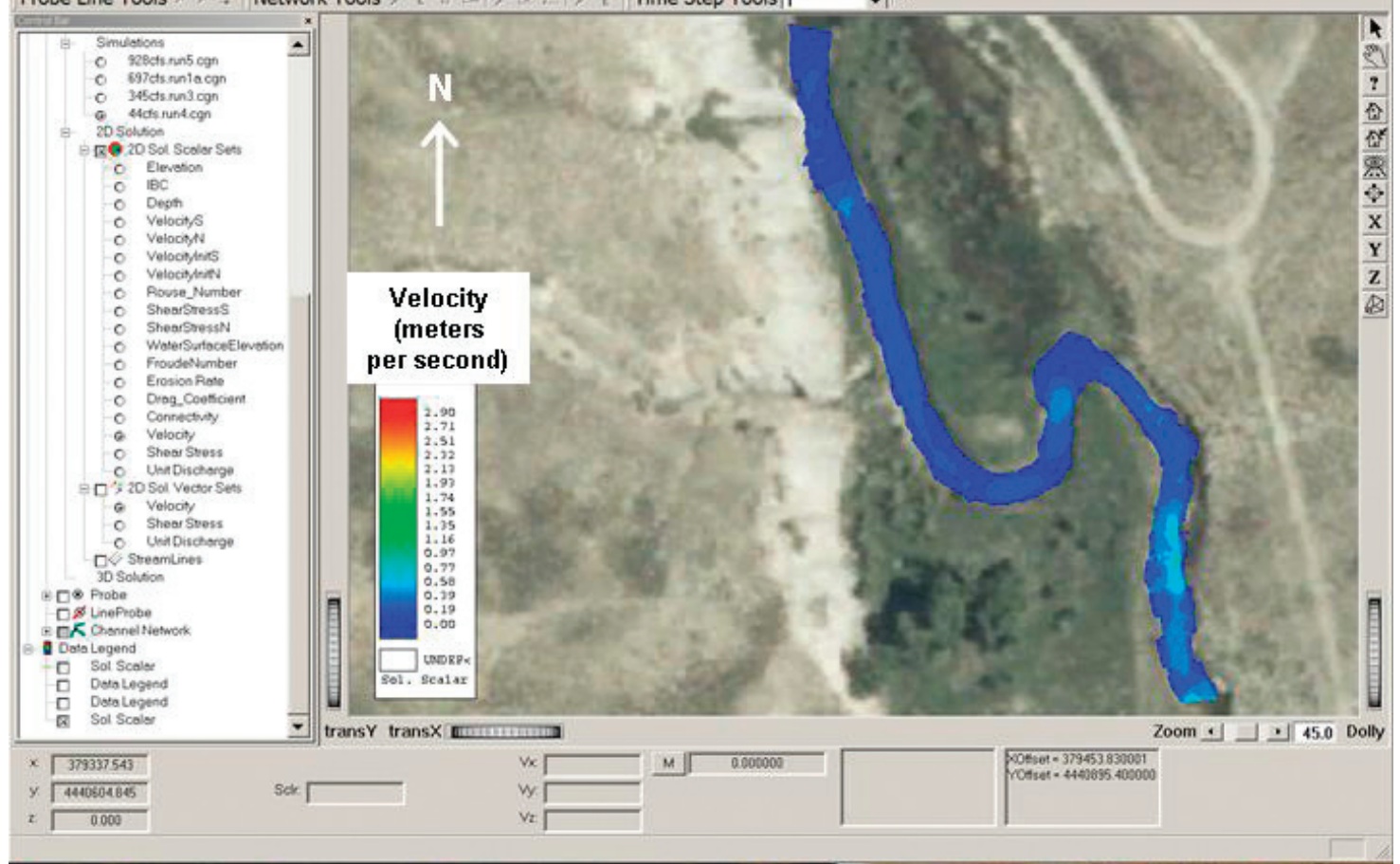

B AllQsModeled1.ed.riv* - MD_SWMS

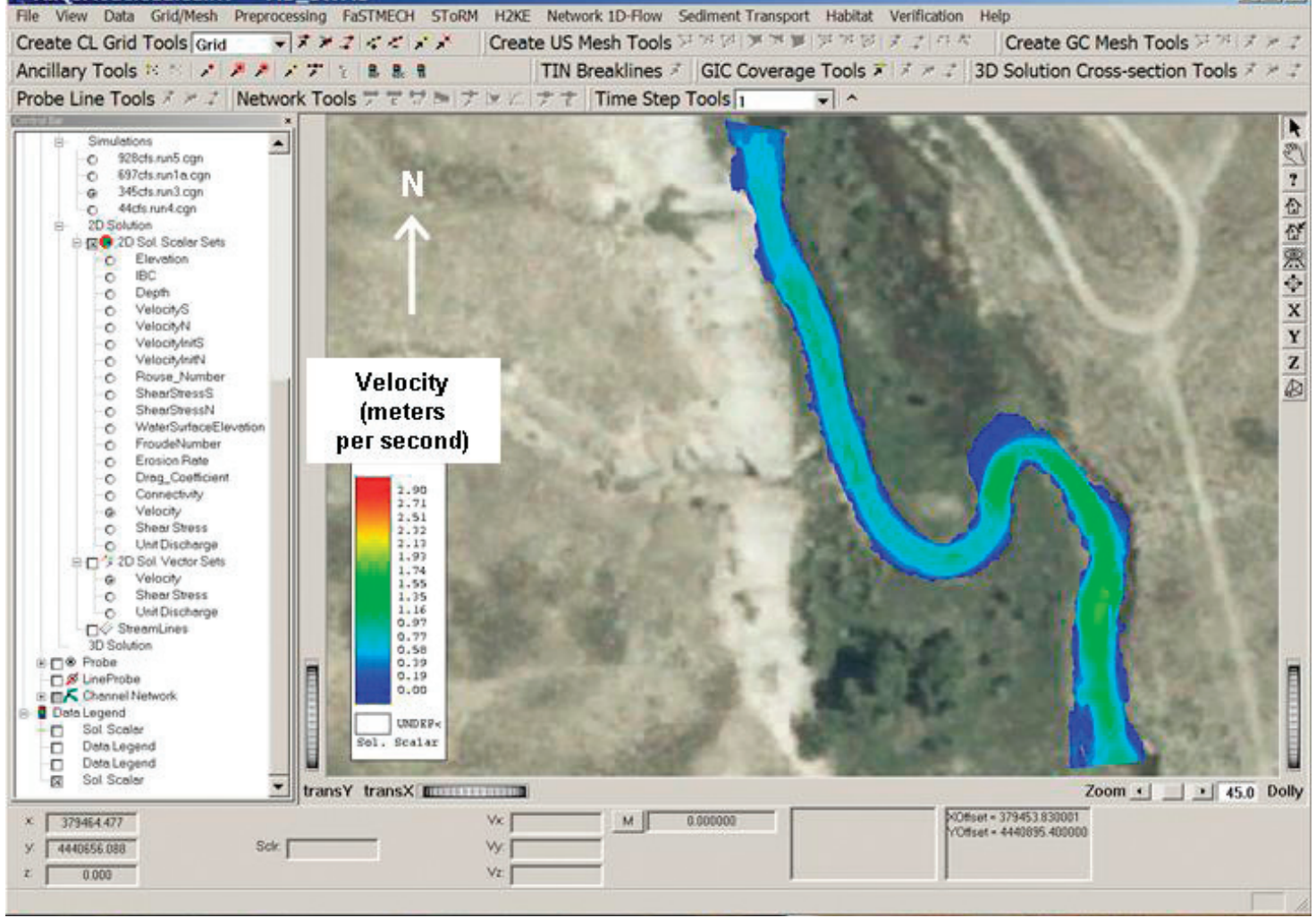

Figure 15. Muddy Creek Reach 1 FaSTMECH model solutions for velocity with discharge of $(A) 1.13$ cubic meters per second (40 cubic feet per second), (B) 9.77 cubic meters per second (345 cubic feet per second), (C) 19.7 cubic meters per second (697 cubic feet per second), and (D) 26.3 cubic meters per second (928 cubic feet per second). 
C AllQsModeled1.ed.riv - MD_SWMS

File View Data Grid/Mesh Preprocessing FaSTMECH STORM H2KE Network 1D-Flow Sediment Transport Habitat Verification Help

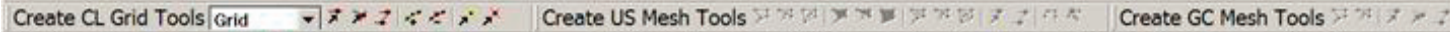

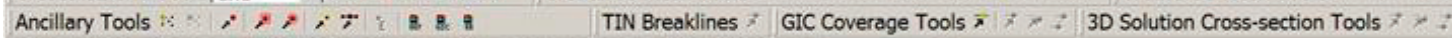

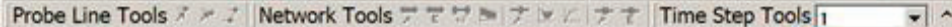

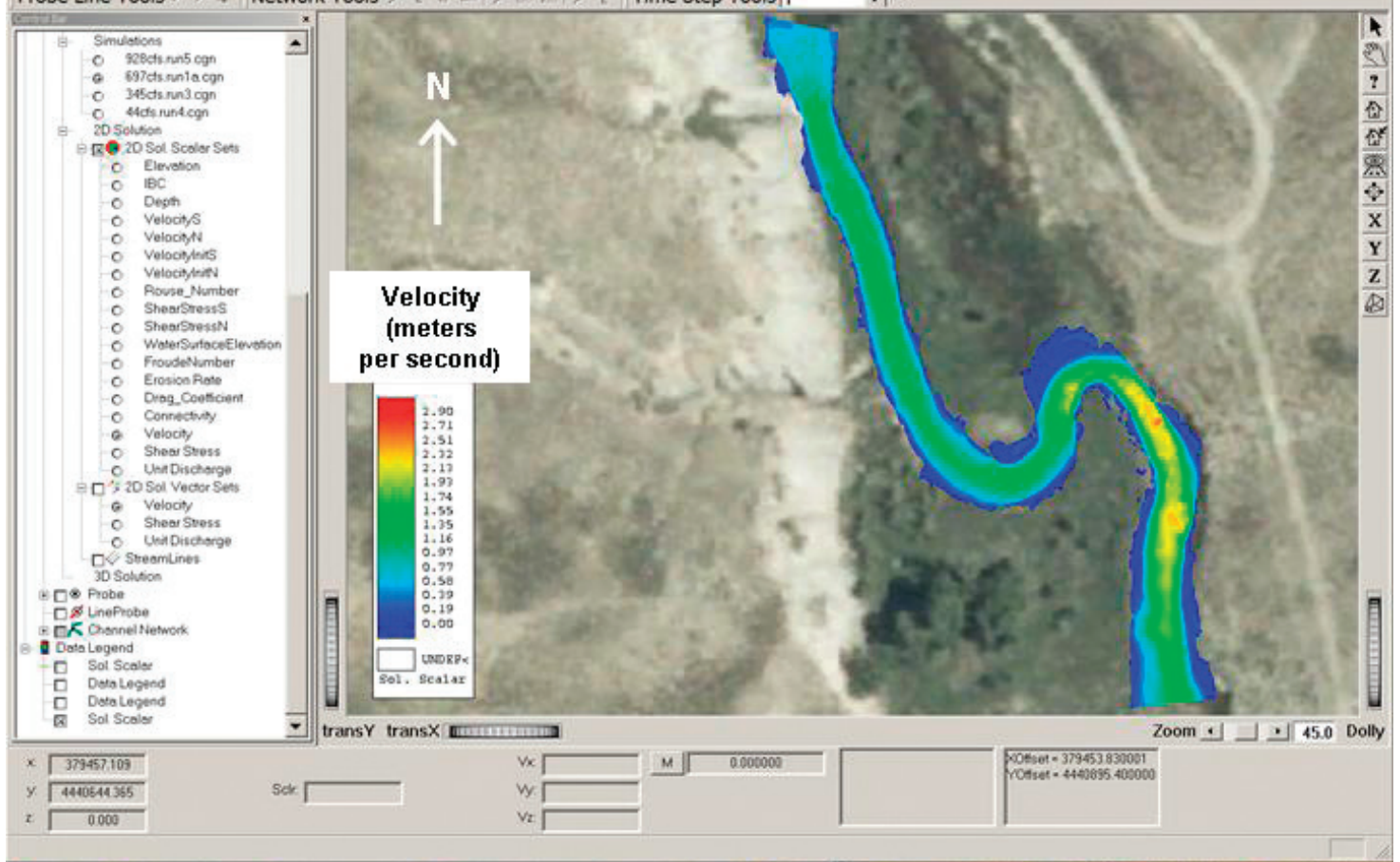

D AllQsModeled1.ed.riv* - MD_SWMS

File View Data Grid/Mesh Preprocessing FaSTMECH SToRM H2KE Network 1D-flow Sediment Transport Habilat Veriflication Help

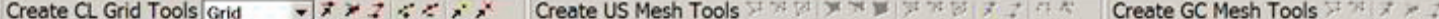

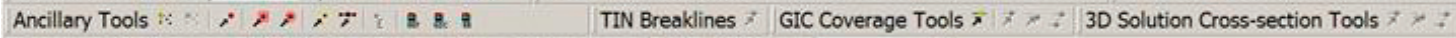

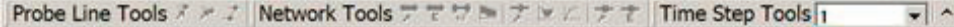

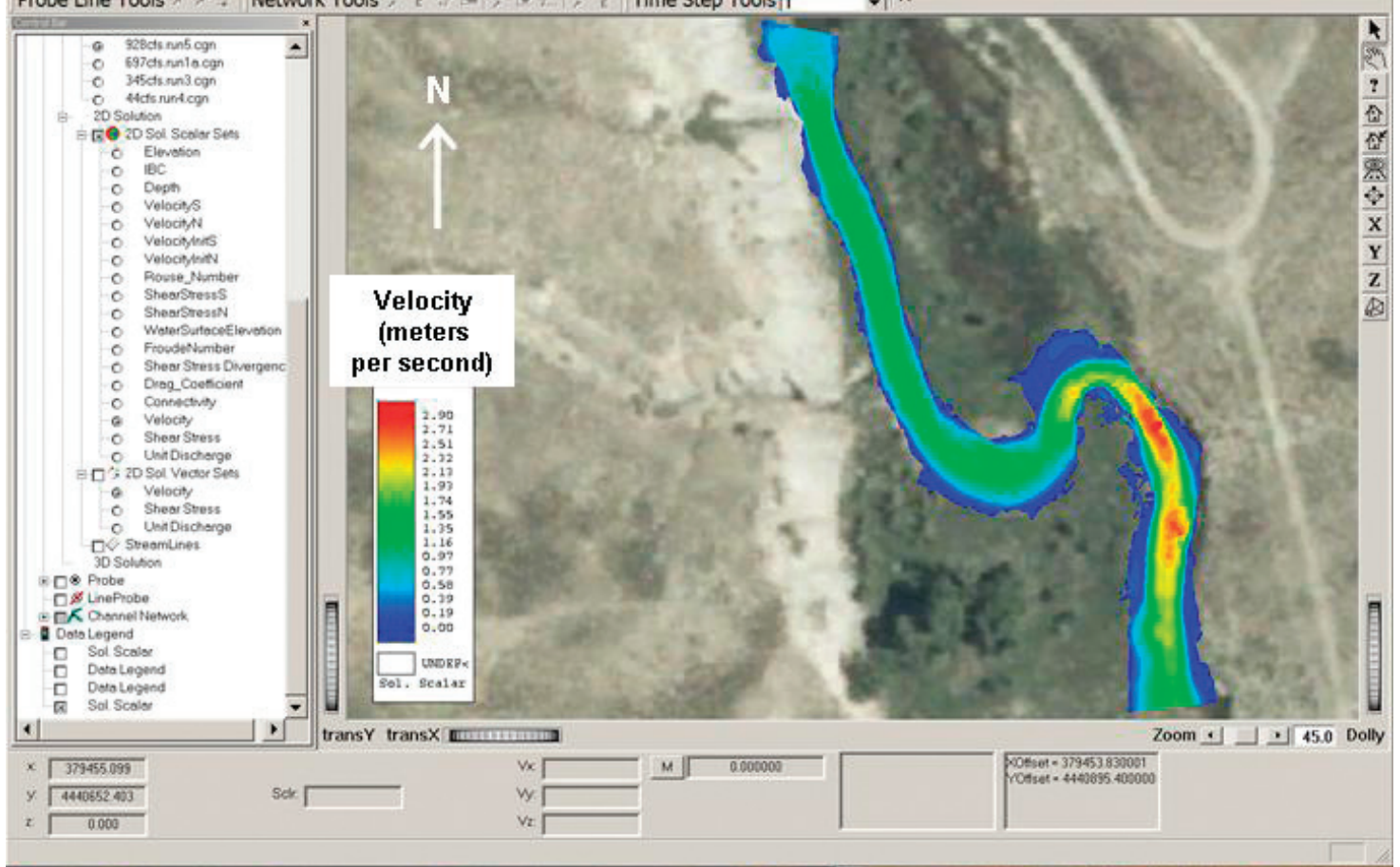

Figure 15-Continued. Muddy Creek Reach 1 FaSTMECH model solutions for velocity with discharge of (A) 1.13 cubic meters per second (40 cubic feet per second), (B) 9.77 cubic meters per second (345 cubic feet per second), (C) 19.7 cubic meters per second (697 cubic feet per second), and (D) 26.3 cubic meters per second (928 cubic feet per second). 
A AllQsModeled1.ed.riv* - MD_SWMS

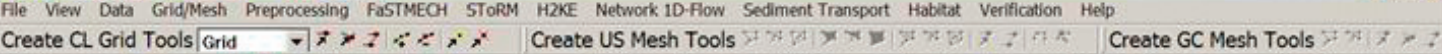

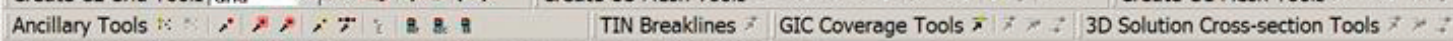

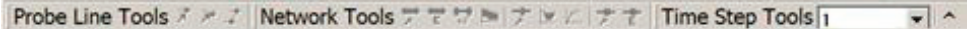

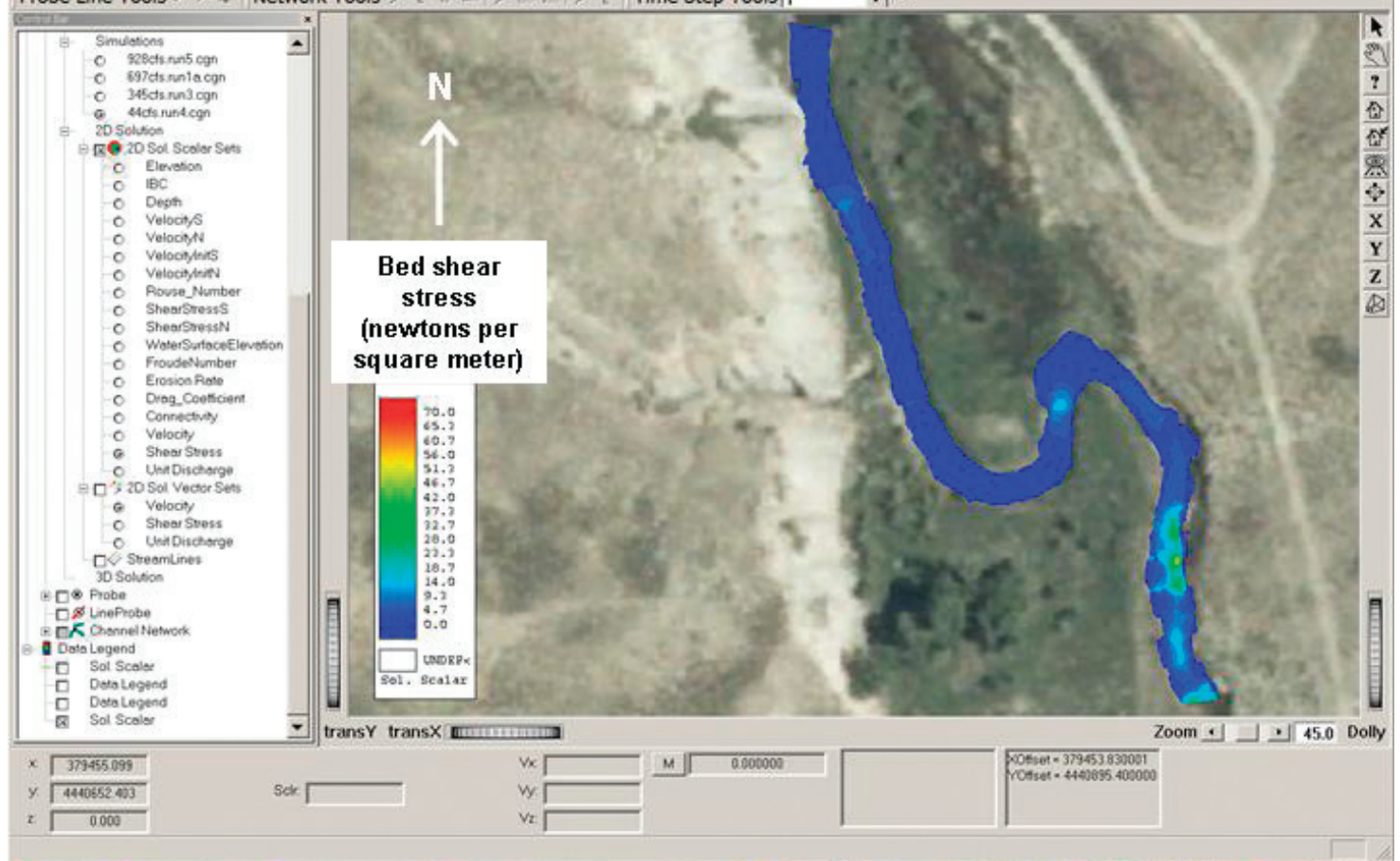

$\boldsymbol{B}$

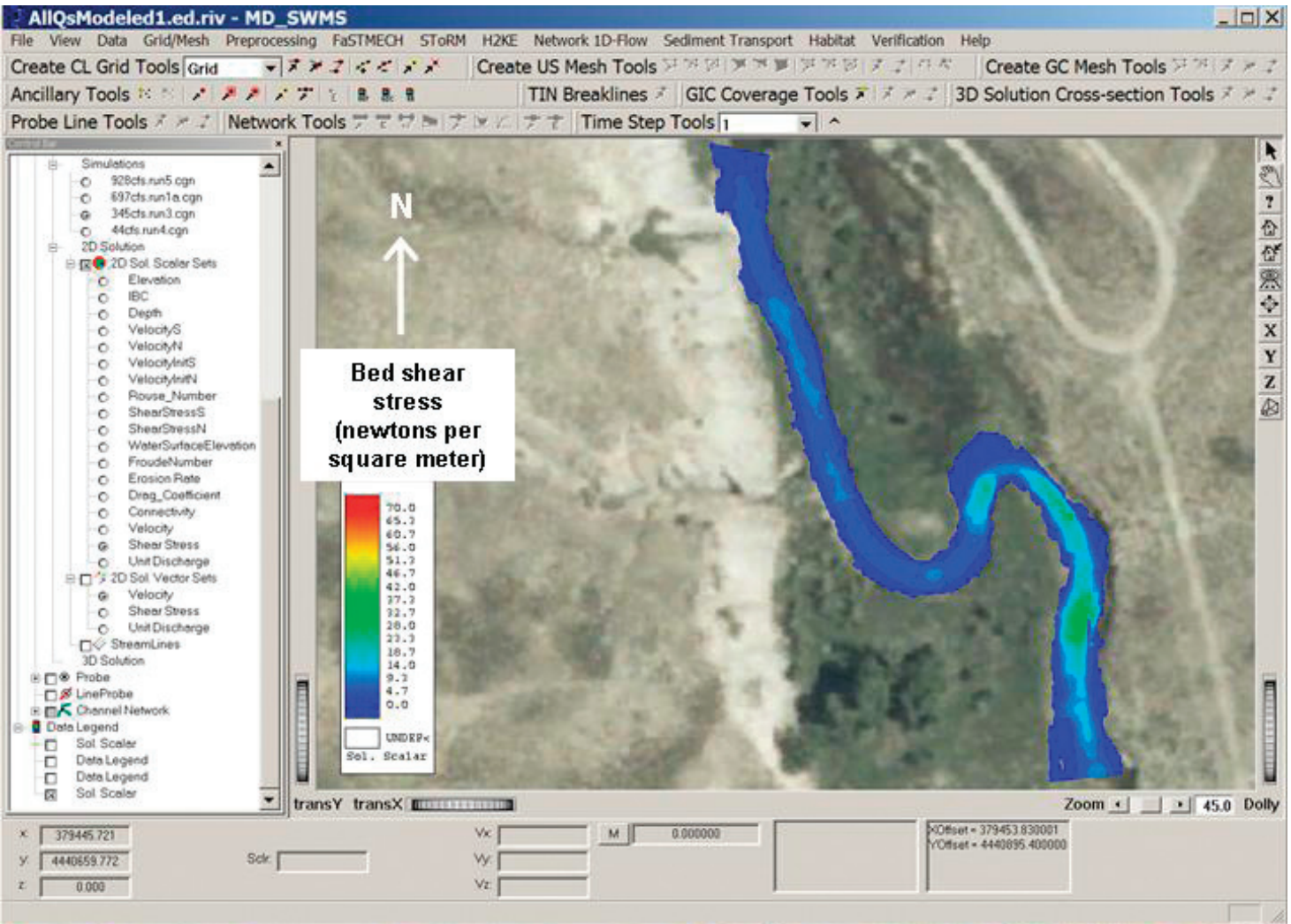

Figure 16. Muddy Creek Reach 1 FaSTMECH model solutions for bed shear stress with discharge of (A) 1.13 cubic meters per second ( 40 cubic feet per second), (B) 9.77 cubic meters per second (345 cubic feet per second), (C) 19.7 cubic meters per second (697 cubic feet per second), and (D) 26.3 cubic meters per second (928 cubic feet per second). 
C AllQsModeled1.ed.riv - MD_SWMS

File View Data Grid/Mesh Preprocessing FaSTMEOH STORM H2KE Network 1D-Flow Sediment Transport Habitat Verification Help

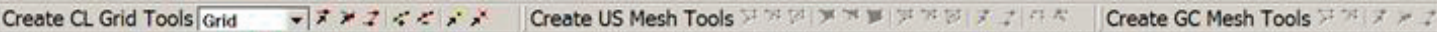

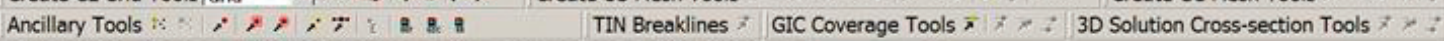

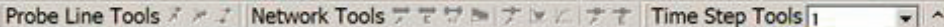

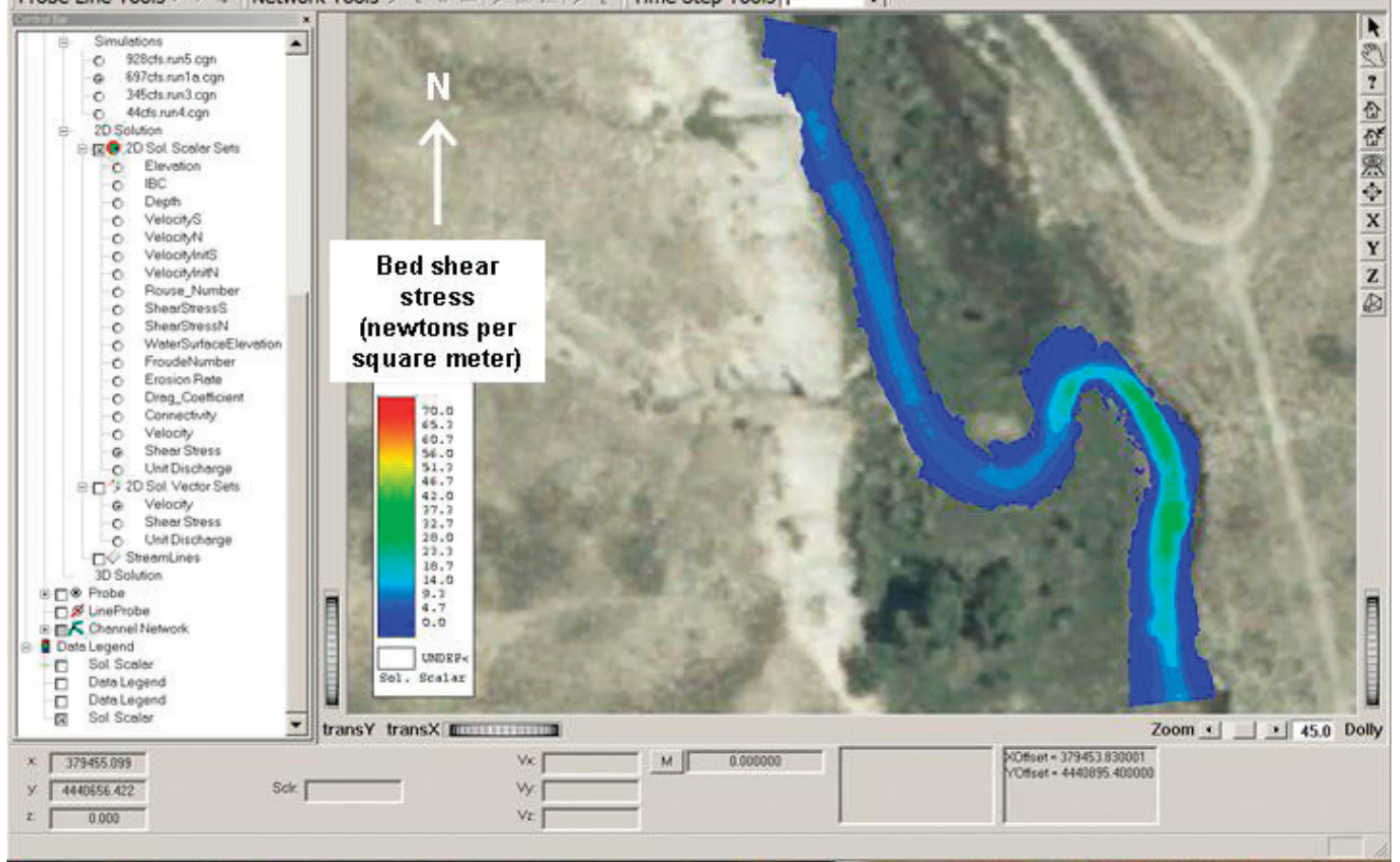

D AllQsModeled1.ed.riv* - MD_SWMS

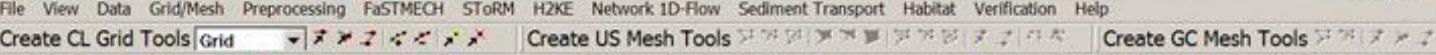

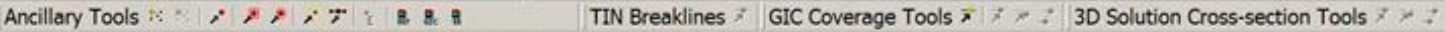

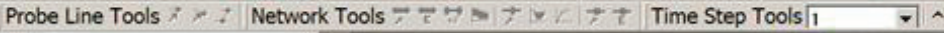

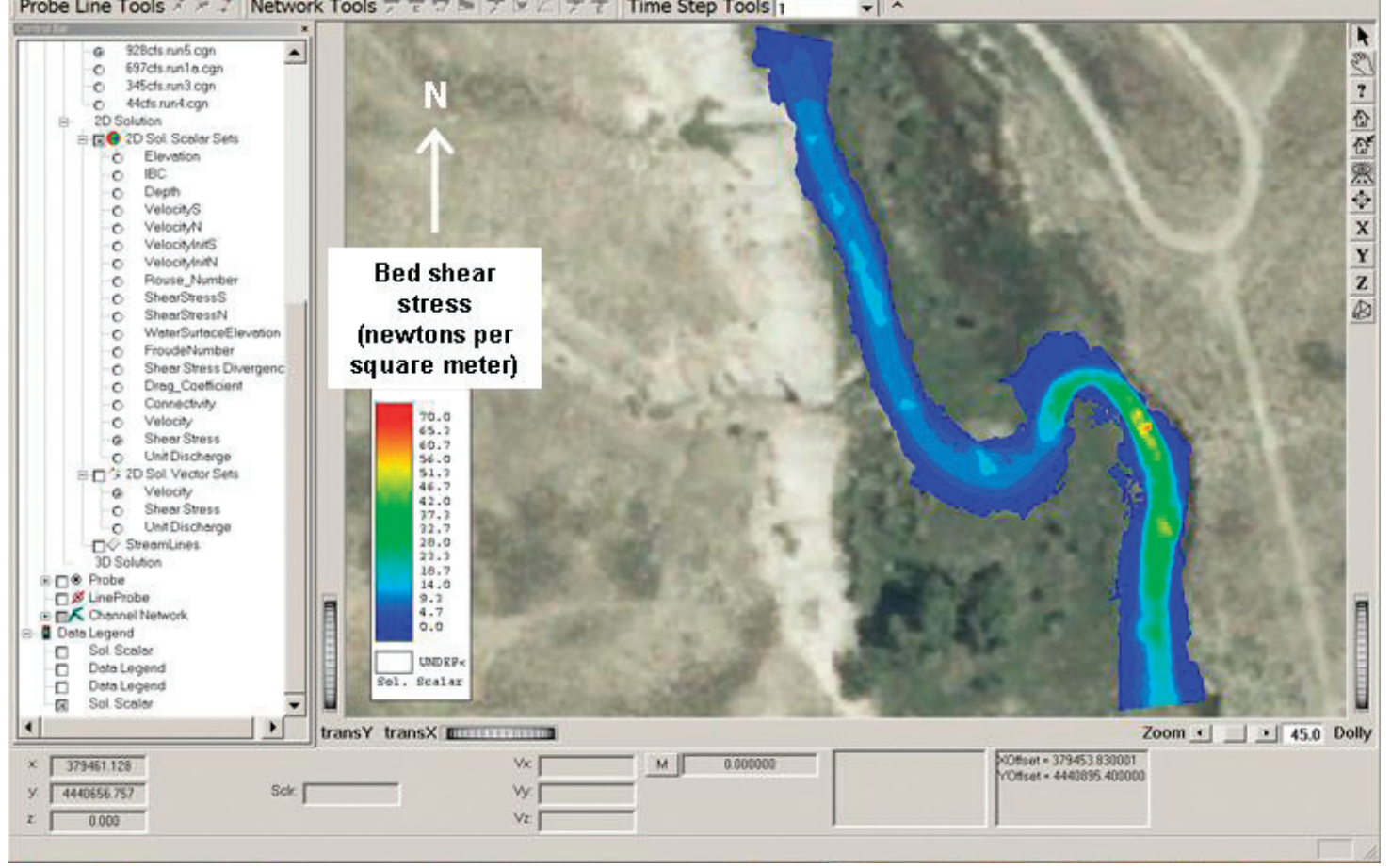

Figure 16 - Continued. Muddy Creek Reach 1 FaSTMECH model solutions for bed shear stress with discharge of $(A) 1.13$ cubic meters per second (40 cubic feet per second), $(B) 9.77$ cubic meters per second (345 cubic feet per second), (C) 19.7 cubic meters per second (697 cubic feet per second), and (D) 26.3 cubic meters per second (928 cubic feet per second). 
A AllQsModeled1.ed.riv - MD_SWMS

$-|\square| x \mid$

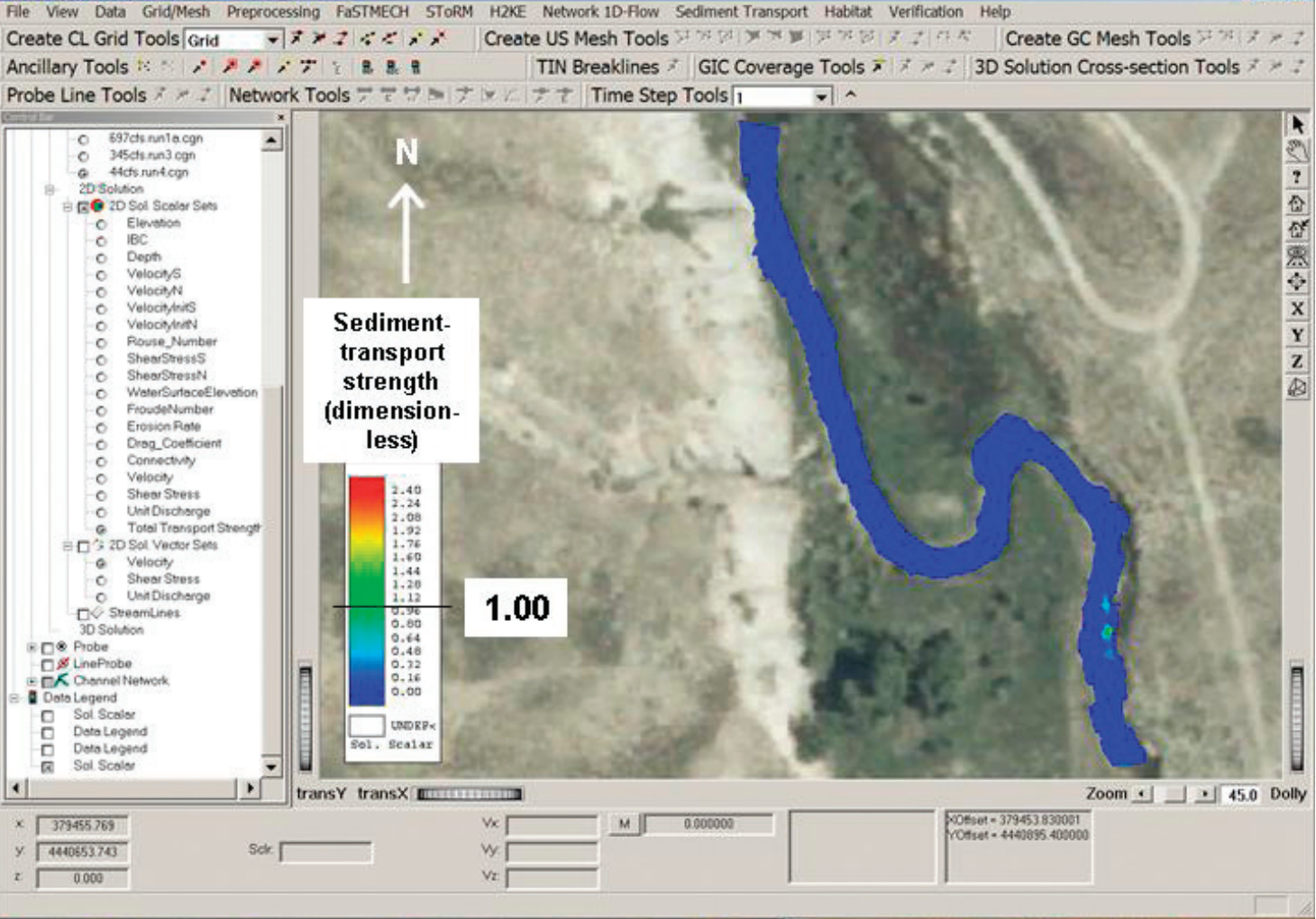

$B$

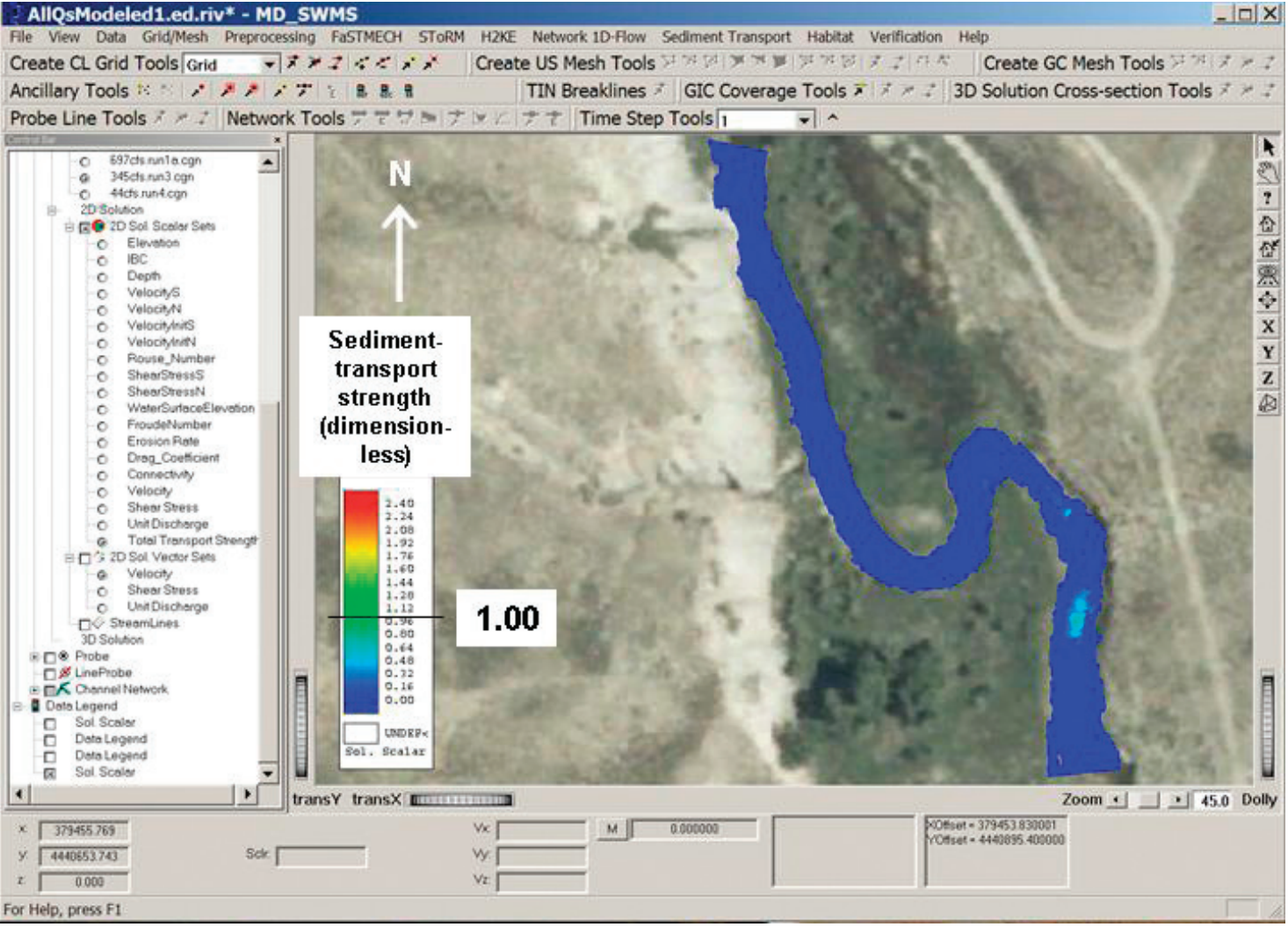

Figure 17. Muddy Creek Reach 1 FaSTMECH model solutions for sediment-transport strength with discharge of $(A) 1.13$ cubic meters per second ( 40 cubic feet per second), $(B) 9.77$ cubic meters per second (345 cubic feet per second), $(C) 19.7$ cubic meters per second (697 cubic feet per second), and (D) 26.3 cubic meters per second (928 cubic feet per second). 
C AllQsModeled1.ed.riv - MD_SWMS

File View Data Grid/Mesh Preprocessing FaSTMECH STORM H2KE Network 1D-flow Sediment Transport Habitat Verification Help

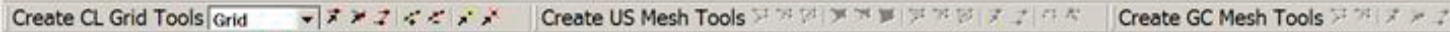

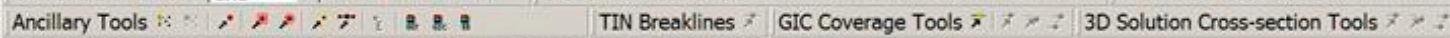

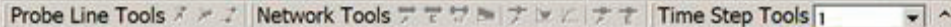

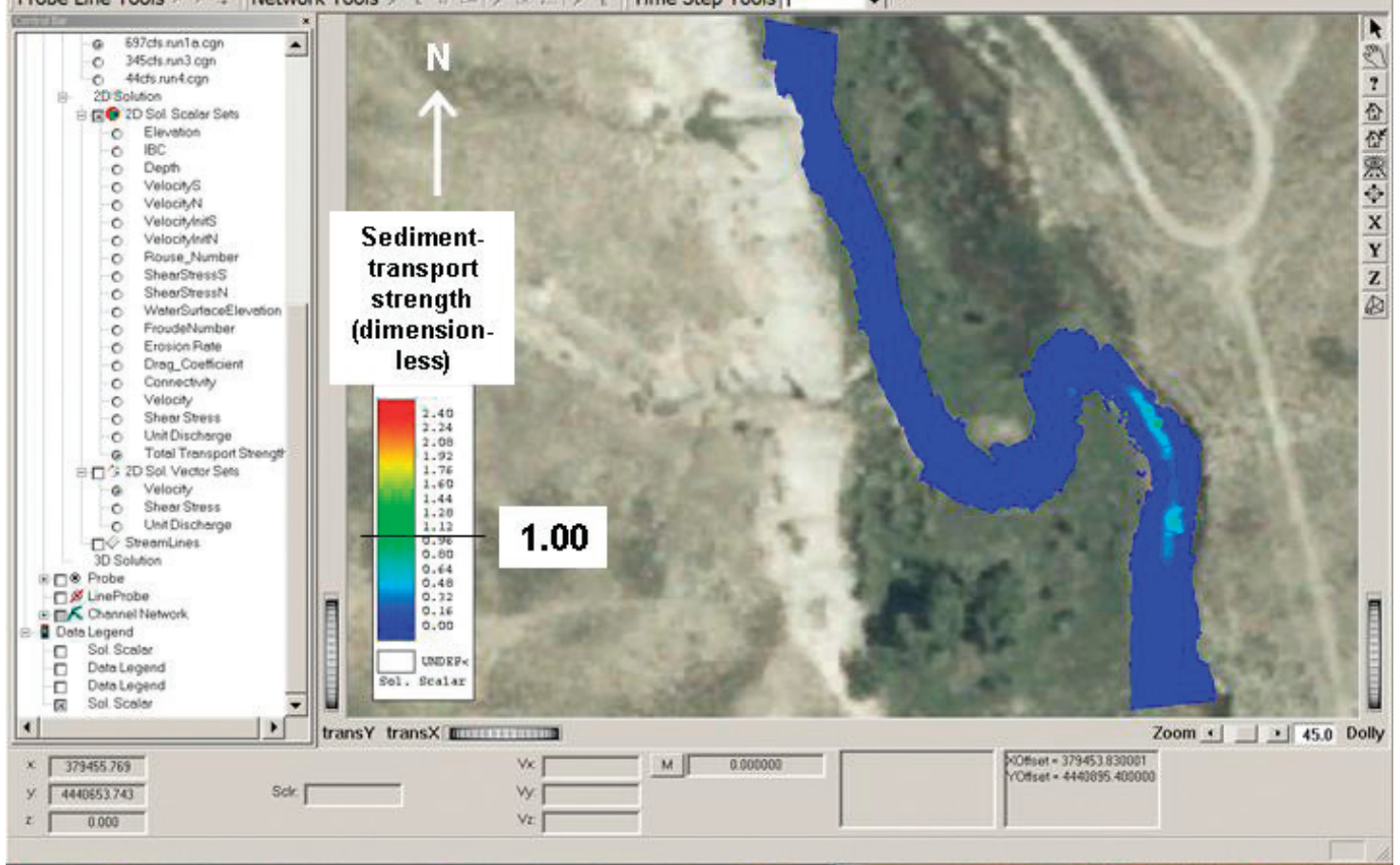

D AllQsModeled1.ed.riv* - MD_SWMS

Data GidMesh Preprocessing FaSTMEOH STORM H2KE Network 1D-Flow Sediment Transport Habitat Verification Help

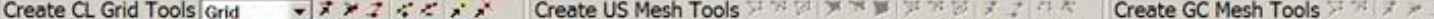

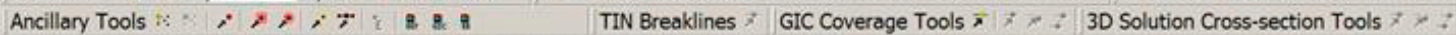

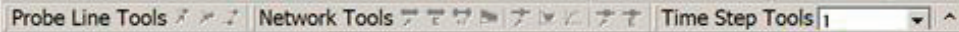

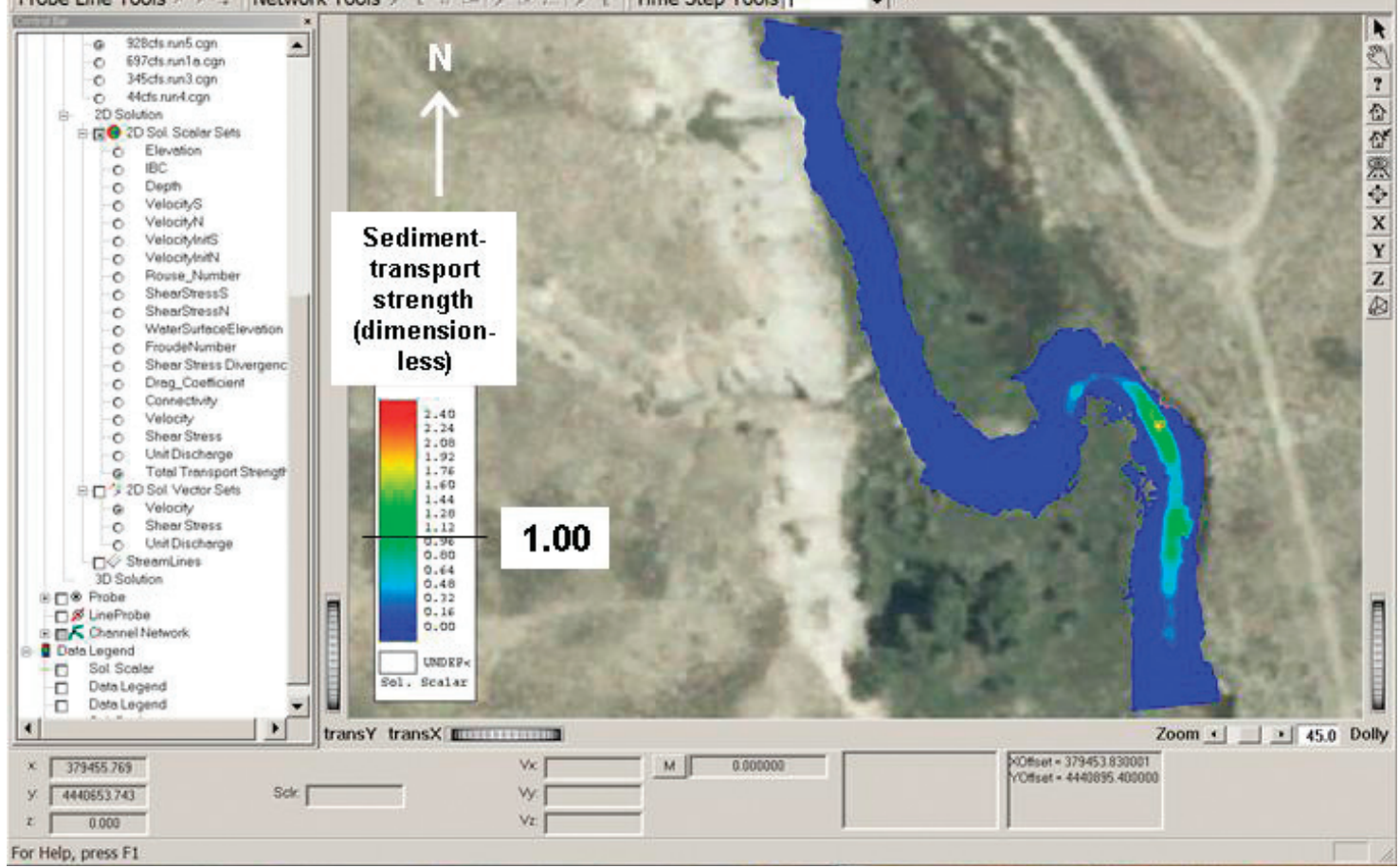

Figure 17-Continued. Muddy Creek Reach 1 FaSTMECH model solutions for sediment-transport strength with discharge of $(A) 1.13$ cubic meters per second ( 40 cubic feet per second), $(B) 9.77$ cubic meters per second (345 cubic feet per second), (C) 19.7 cubic meters per second (697 cubic feet per second), and (D) 26.3 cubic meters per second (928 cubic feet per second). 


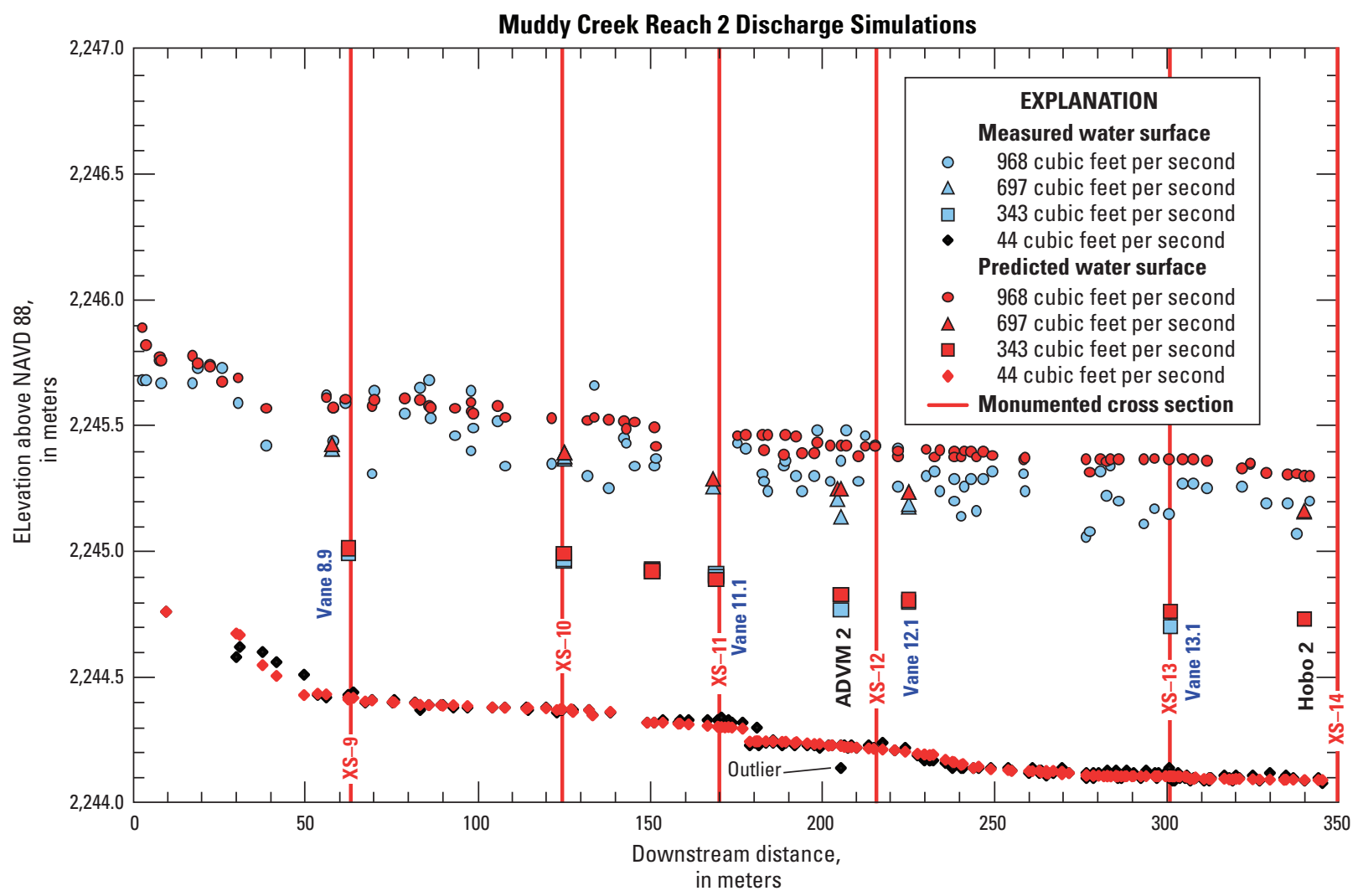

Figure 18. Longitudinal profile of measured and predicted water-surface elevations from Muddy Creek reach 2, at 44, 343, 697 , and 968 cubic feet per second.

\section{Observed and Potential Geomorphic Changes}

Relatively minor and isolated geomorphic changes have been observed since 2001 in reach 1 , the control reach where no reconfiguration was done, and since 2003 in reach 2 , where reconfiguration was done in late 2003. In reach 2 , some streambed locations, excavated during reconfiguration, have aggraded to their former elevations (fig. 11). Replicate channel surveys and photographs are available online at: http://co.water.usgs.gov/projects/rcmap/MuddyCreek/ indexmuddycreek.html (accessed April 28, 2010).

Sediment sampled immediately after reconfiguration in 2003 at an alluvial bar near cross section 10 was poorly sorted and had a large percentage of sand, perhaps reflecting recent disruptive activities. A comparable alluvial bar nearby at cross section 12 (fig. 4) was better sorted in 2008, possibly showing the cumulative effects of entrainment and redeposition during the high peak discharges of 2006 and 2008 (fig. 8). However, because this bar surface can be inundated by discharges as low as $343 \mathrm{ft}^{3} / \mathrm{s}$, it is possible that fine sediment was removed and gravels were sorted and redeposited by discharges less than the 2006 and 2008 peak discharges. These geomorphic and sedimentologic observations indicate that the large discharges of 2006 and 2008 had minimal effect on channel geometry at most locations in the monitoring reaches and that these reaches have been relatively stable under the flow regime since 2001 .

The channel geometry was similar in reaches 1 and 2 at low and medium discharges, but cross-section geometries and the wetted areas at higher discharges were somewhat different (figs. 9-12). Results from model simulations indicated that flood-plain areas were inundated by the high $\left(697 \mathrm{ft}^{3} / \mathrm{s}\right)$ and outof-bank flood (928 and $968 \mathrm{ft}^{3} / \mathrm{s}$ ) discharges (figs. 14 and 19). Differences in inundation areas between reaches 1 and 2 at comparable high and flood discharges could be due to geomorphic differences in flood-plain topography, or incision of the channel in reach 1 to some unknown degree since construction of the Ritschard Dam and Wolford Mountain Reservoir, or increased roughness from the reach 2 boulder structures sufficient to increase water-surface elevation for these discharges. The valley floor is narrow in reach 1 , and a high scarp at the distal margin of an alluvial fan on the east side of the valley prevents flooding in this area (figs. 2 and 14). Conversely, reach 2 is unconfined, and low-relief surfaces and former channel segments facilitate inundation (figs. 2 and 19).

Model simulations of bed shear stress generally indicated high values in areas of the greatest depth or velocity, such as in meander bends (where depths were greater) and in steeper gradient areas (where velocities were greater). Simulated 
high shear-stress areas in reach 1 generally occurred from the vicinity of cross section 4 to the end of the modeled reach downstream from cross section 5 (figs. 3 and 16). The simulated high bed shear stress near cross section 4 was a result of the greater local depths at each reference discharge (figs. $14 C$ and $D$ ), whereas the high bed shear stress near cross section 5 was a result of steeper gradient (fig. 13). Simulated high shearstress areas in reach 2 followed the same general distribution as in reach 1 . The greatest bed shear stresses in reach 2 were in the vicinity of cross section 9 (figs. $21 C$ and $D$ ) where the gradient was the steepest (fig. 18).

Contrary to the general form of bed shear stress, (represented by the duBoys equation, $\tau=\gamma \mathrm{DS}$ ) where shear stress $\left(\tau_{\mathrm{o}}\right)$ is proportional to depth $(\mathrm{D})$ and slope $(\mathrm{S})$, is the FaSTMECH calculation of bed shear stress, where shear stress is proportional to velocity in the down-channel and cross-channel directions (Berenbrock and Tranmer, 2008, equation 3). Although great depths were observed near cross section 13 in reach 2 (figs. $19 C$ and $D$ ), bed shear stress remained relatively low in these deep areas (figs. $21 C$ and $D$ ) because velocities were low (figs. $20 C$ and $D$ ). The highest bed shear stresses near cross section 13 occurred at high and out-of-bank discharges on an adjacent point bar (figs. 21C and $D$ ) where flow depths were shallow (figs. $19 C$ and $D$ ) but where velocities were great relative to velocities in the deeper part of cross section 13 (figs. $20 C$ and $D$ ). Onsite observations of the point bar near cross section 13 after the 2008 peak discharge supported the simulated bed shear stress for high- and out-of-bank discharges. The point bar consisted of reworked gravel, whereas the adjacent pool was filled with a thick layer of fine, unconsolidated sediment.

Locally high bed shear stresses at 44 and $343 \mathrm{ft}^{3} / \mathrm{s}$ were created by boulder structures, such as cross-vane 11.1 (figs. 4 , $6,21 A$, and $21 B$ ), that were designed to converge flow paths and accelerate velocities (figs. $23 A$ and $B$ ). The effects of these boulder structures on local bed shear stress appear to be diminished at higher discharges and greater flow depths (figs. $21 C$ and $D$ ), although the effect on velocity appears to propagate downstream (fig. $23 C$ and $D$ ). Effects of boulder riprap along banks in meandering sections of reach 2 were not evaluated; however, bank retreat in reach 1 , where banks were not protected by riprap, was relatively minor except at cross section 6 .

The potential for sediment mobility, or sediment entrainment, is represented by sediment-transport strength (TS) in FaSTMECH. Simulated TS values less than 1 are indicative of hydraulic conditions that are insufficient for widespread entrainment of the streambed $\mathrm{d}_{50}$ sediment-particle size, whereas TS values greater than 1 are indicative of widespread sediment mobility of that particle size. TS values were less than 1 for the streambed $d_{50}$ in most areas of reaches 1 and 2 for low, middle, and high discharges, as indicated by the blue colors in figures $17 A, B, C$, and $22 A, B$, and $C$. Sedimenttransport strength conditions greater than 1 (green and yellow colors) developed for the out-of-bank discharge simulations in limited streambed areas, generally where the channel gradient was greatest (figs. $17 D$ and $22 D$ ). The model simulations indicate that widespread entrainment of the streambed $\mathrm{d}_{50}$ occurs only in isolated subreaches at discharges slightly above bankfull conditions in reaches 1 and 2. The finer, alternate bar gravels at cross sections 10 and 12 (fig. 8) are mobilized by lesser discharges than those needed to mobilize the coarser streambed gravels (simulations with bar $\mathrm{d}_{50}$ are not shown in this report).

Variations in TS, where mobile subreaches alternate with immobile subreaches, could have resulted in sediment redistribution, median particle-size variation, and alluvial bar development observed in the modeled reaches. Examples in Muddy Creek reach 2 include the locally deep pools downstream from boulder cross vanes (fig. 23), gravel accumulation on the upstream side of most cross vanes (fig. 6), streambed aggradation in previously excavated, reconfigured cross sections (figs. 11 and 12), and gravel sorting and accumulation in alluvial bars at cross sections 10 and 12 (fig. 8).

The small areas of potential streambed mobility identified by the model simulations indicate that the Muddy Creek channel in reaches 1 and 2 is relatively stable at discharges up to and slightly greater than the approximate "bankfull" discharge. This conclusion is supported by crosssection surveys in 2003, 2006, and 2008 that show little or no geomorphic change in response to out-of-bank flood events in 2006 and 2008 (figs. 9-12, and cross-section surveys on the RCMAP Web site: http://co.water.usgs.gov/projects/rcmap/ MuddyCreek/indexmuddycreek.html, accessed April 28, 2010).

Constructed boulder features in reach 2 have been monitored since their installation in 2003. Riprapped banks in reach 2 meander bends did not retreat during the monitoring period, as indicated by replicate surveys in 2003, 2006, and 2008 at cross sections $8,11,12$, and 13 (see RCMAP Web site). By contrast, the meander bend at cross section 15 was not protected with riprap and has retreated approximately $1.2 \mathrm{~m}$ since 2003.

Boulder cross vanes redirected and concentrated discharge (shown by the velocity vectors at cross vane 11.1 in figure 23) in all simulations and created locally high shearstress areas in reach 2 (figs. $21 A$ and $B$ ). Onsite observations indicated a deepening and coarsening of the streambed immediately downstream from the cross vanes. These conditions generally favor specific aquatic organisms, such as salmonids and their food supply (Hickman and Raleigh, 1982; Raleigh and others, 1986). The cross-vane contribution to lateral channel stability in reach 2 could not be determined from the available data because cross vanes in the simulation reach all were constructed in conjunction with an adjacent riprapped bank.

The minor geomorphic changes from 2001 to 2008 in the reach 2 channel were comparable in scale and location to the minor changes in reach 1 during the same time period, indicating that the flow-directing boulder structures and the streambank riprap might not have been necessary to maintain the channel pattern and position in reach 2 . 
A AllQModeled2.ed.riv - MD_sWMS

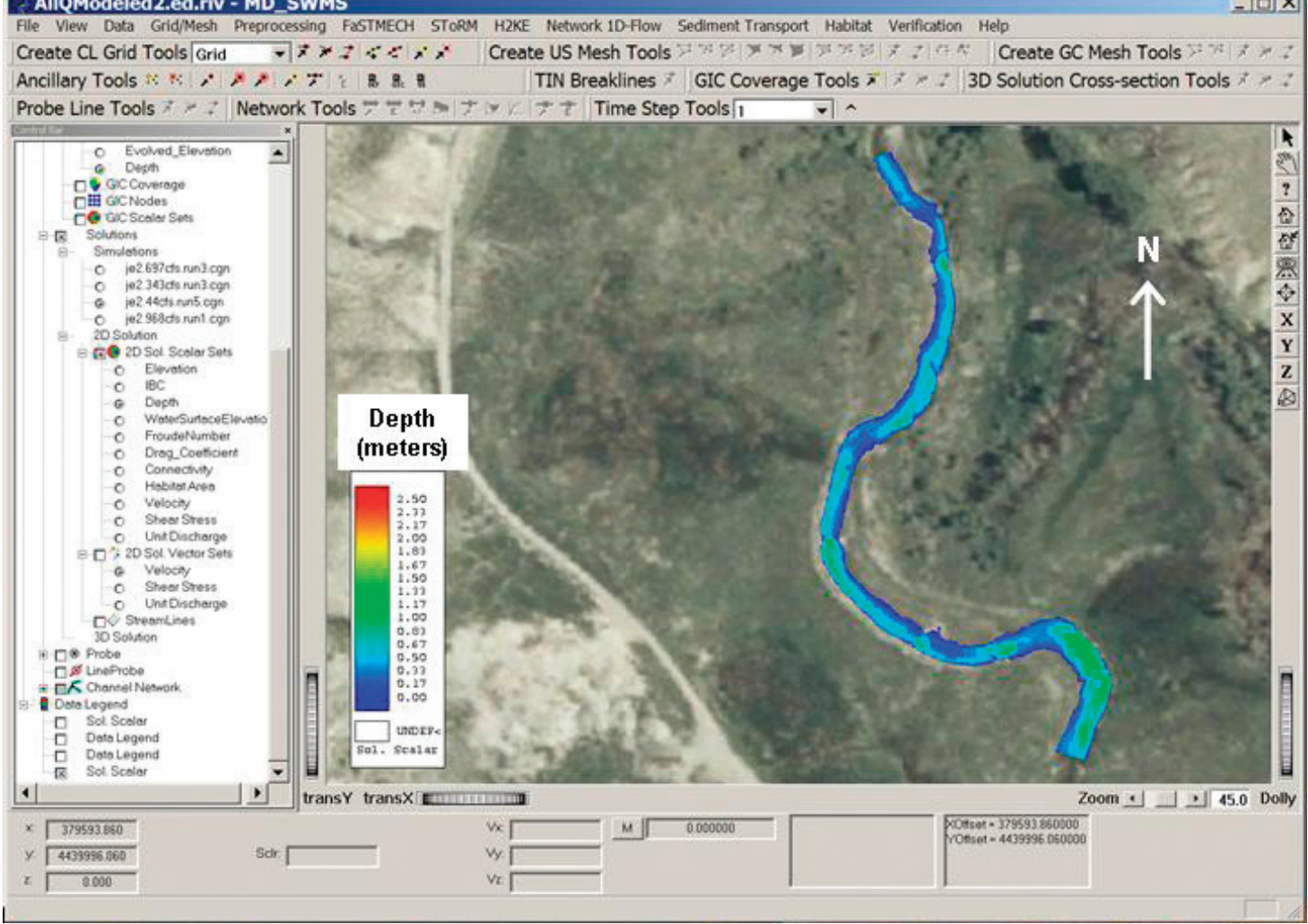

B AllQModeled2.ed.riv - MD SWMS

File Vlew Dota Grid/Mesh Preprocessing FaSTMECH STORM HZKE Network 1D-Flow Sediment Transport Habltat Verifiation Help-

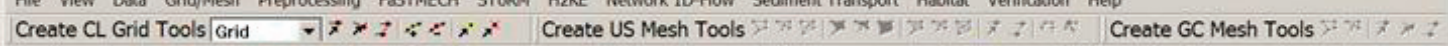

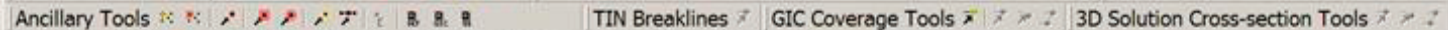

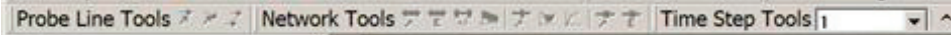

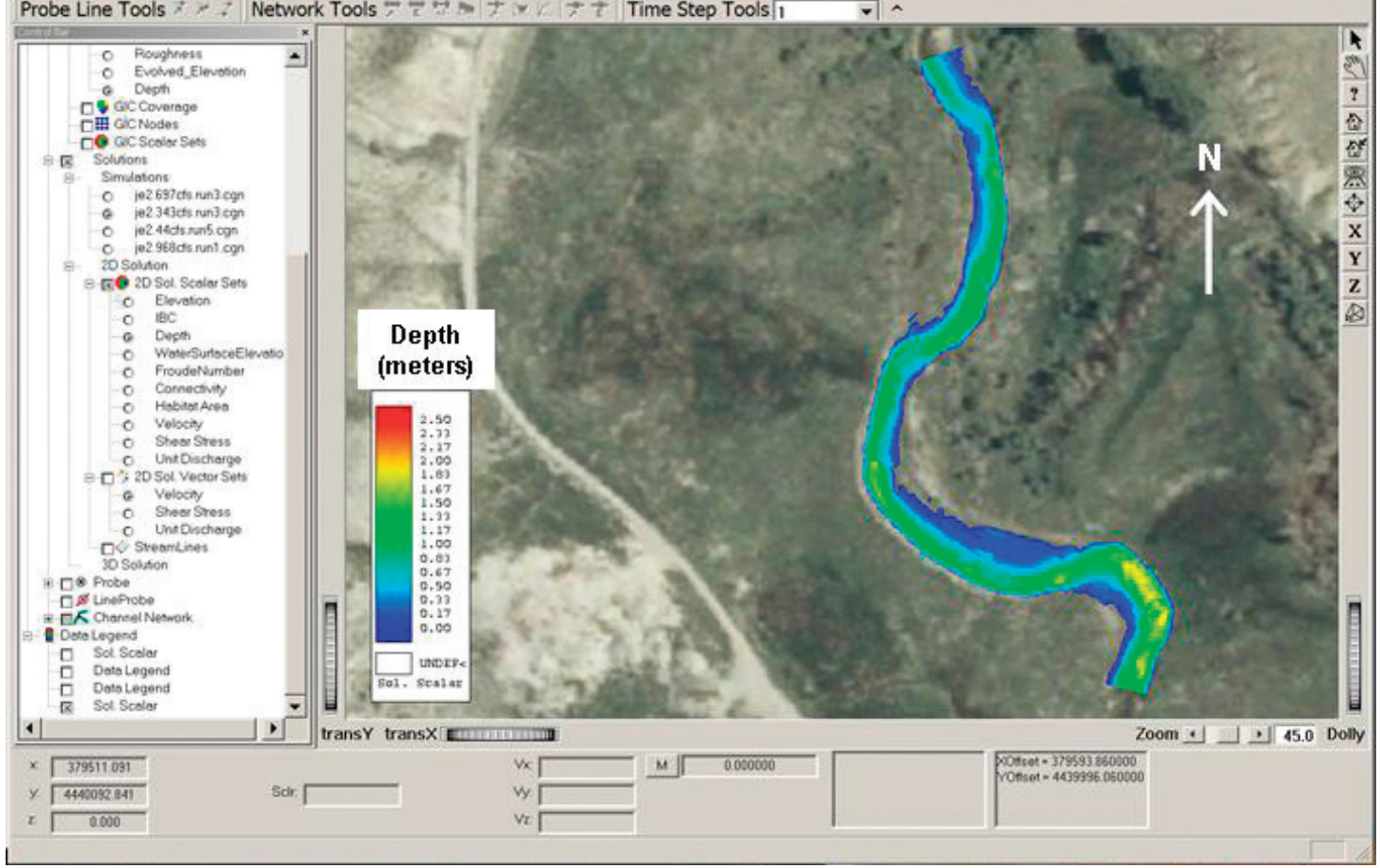

Figure 19. Muddy Creek Reach 2 FaSTMECH model solutions for depth with discharge of $(A) 1.25$ cubic meters per second (44 cubic feet per second), (B) 9.71 cubic meters per second (343 cubic feet per second), (C) 19.7 cubic meters per second (697 cubic feet per second), and (D) 27.4 cubic meters per second (968 cubic feet per second). 
C AllQModeled2.ed.riv - MD SWMS

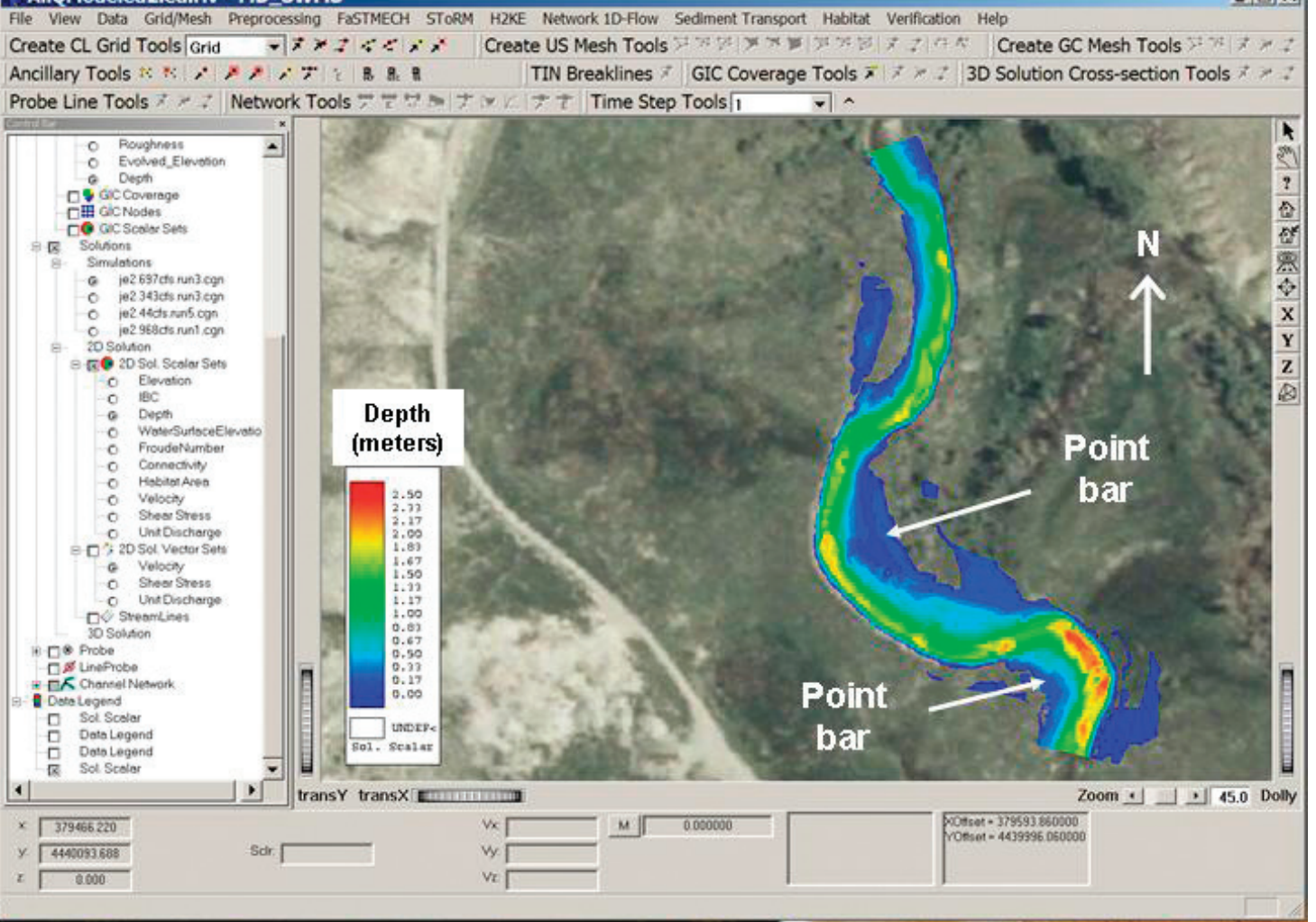

D AllQModeled2.ed.riv - MD SWMS

File Vlew Data Grid/Mesh Preprocessing FaSTMECH STORM HZKE Network 1D-Flow Sediment Transport Habitat Verification Help

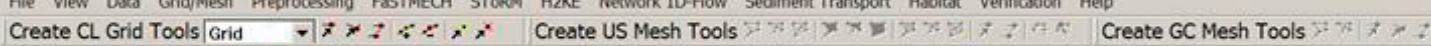

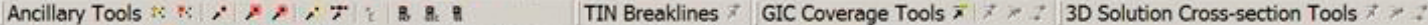

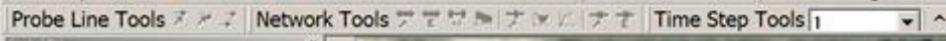

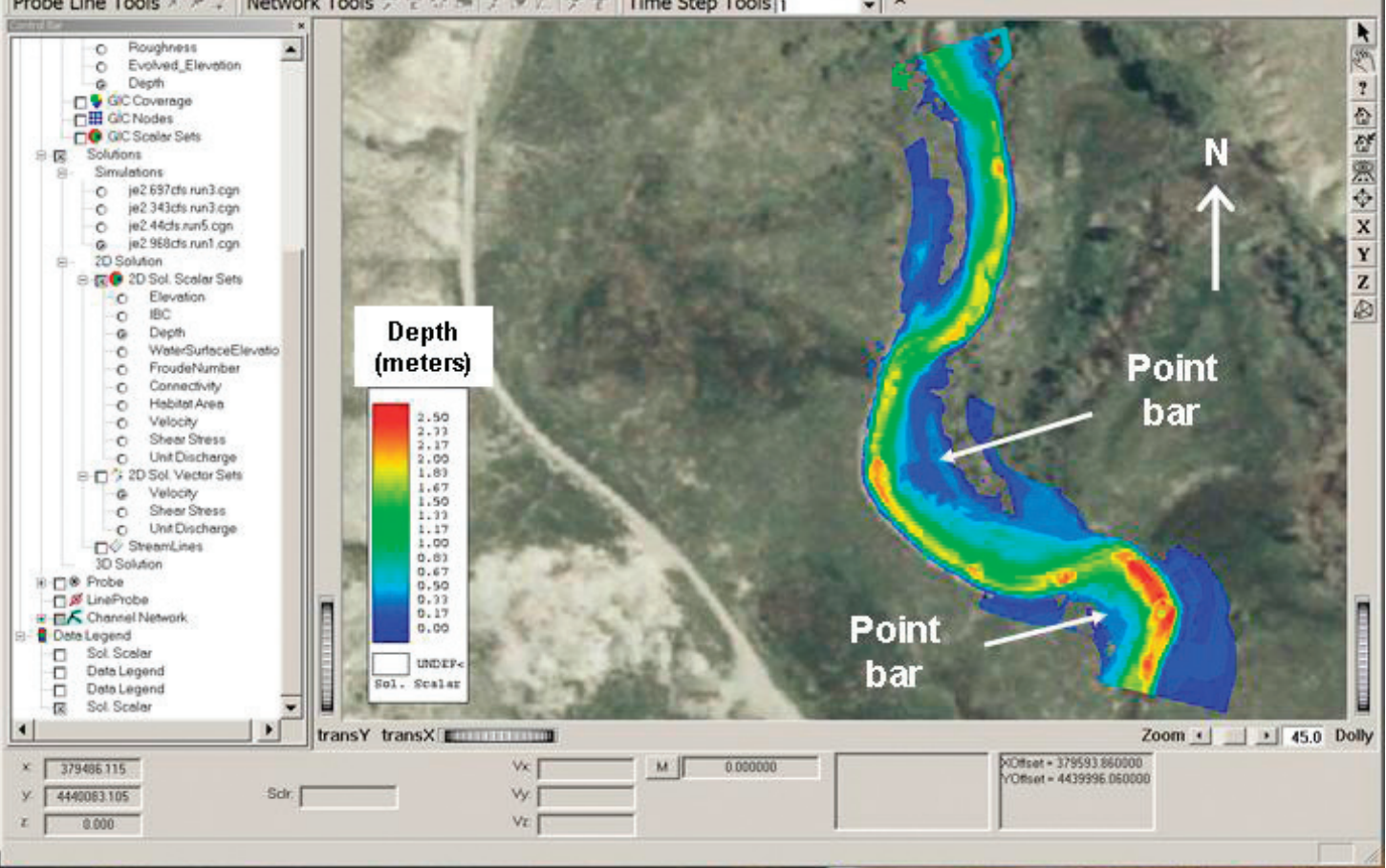

Figure 19-Continued. Muddy Creek Reach 2 FaSTMECH model solutions for depth with discharge of (A) 1.25 cubic meters per second (44 cubic feet per second), (B) 9.71 cubic meters per second (343 cubic feet per second), (C) 19.7 cubic meters per second (697 cubic feet per second), and (D) 27.4 cubic meters per second (968 cubic feet per second). 


\section{A AllQModeled2.ed.riv - MD_SWMS}

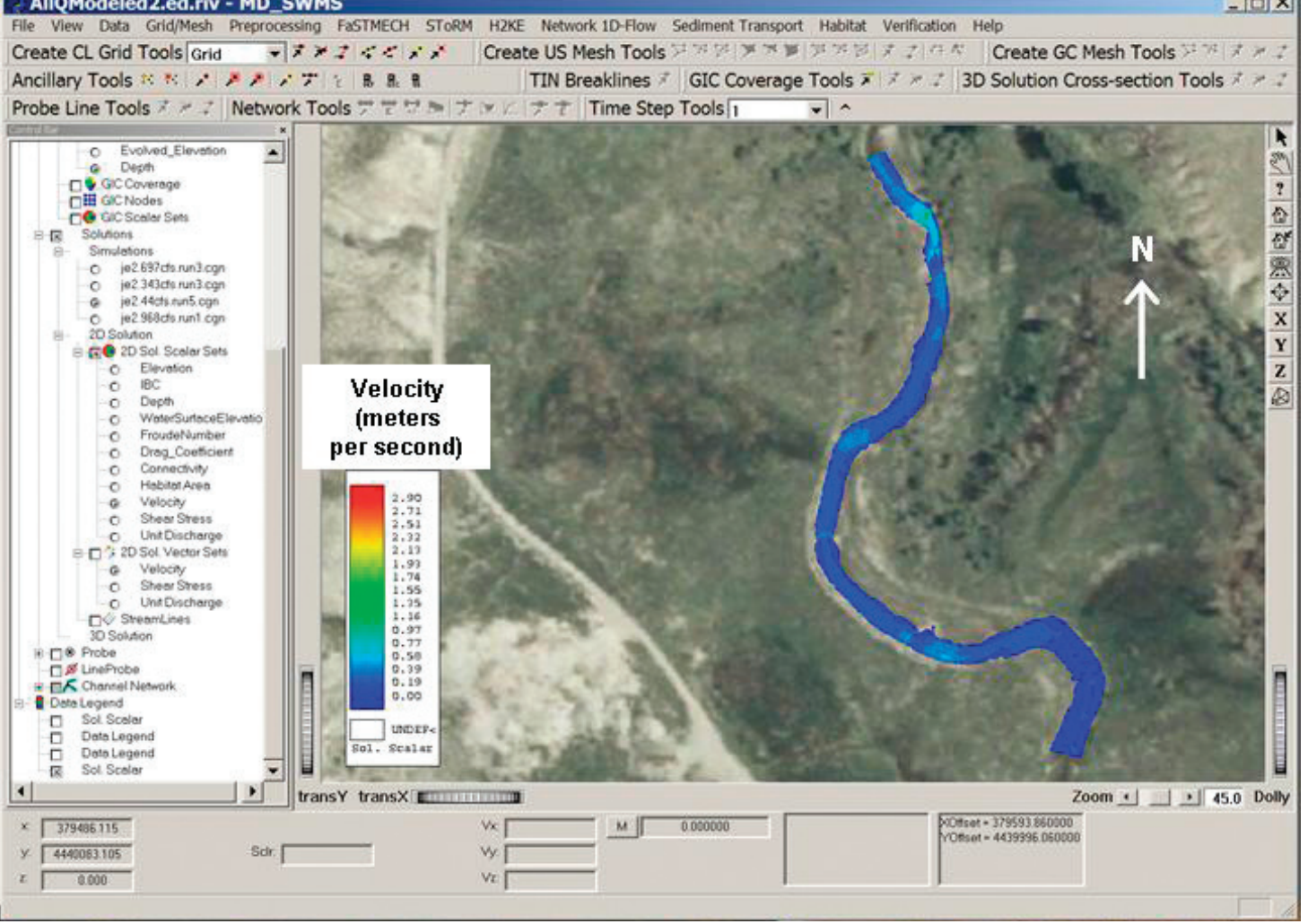

B AllQModeled2.ed.riv - MD_SWMS

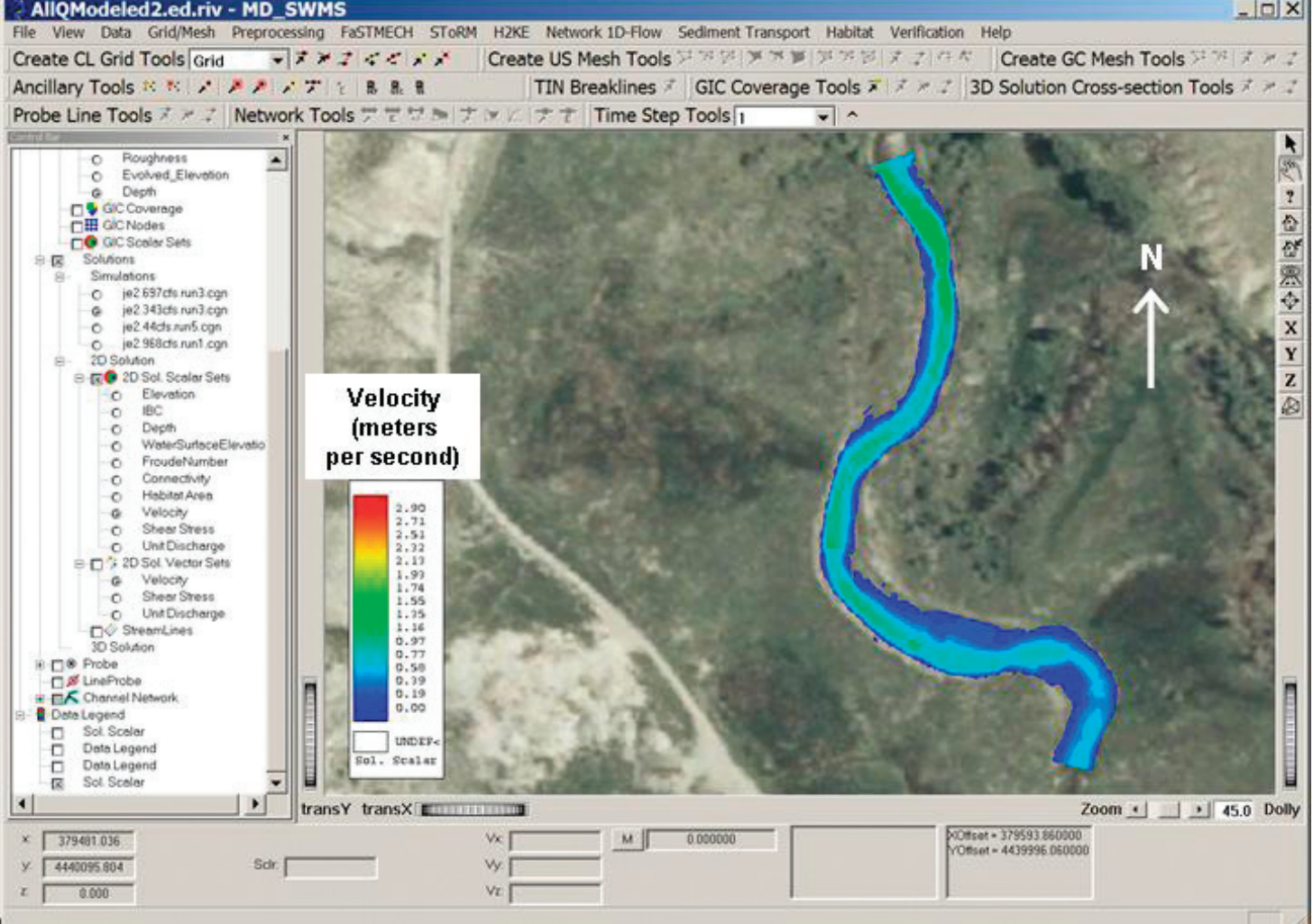

Figure 20. Muddy Creek Reach 2 FaSTMECH model solutions for velocity with discharge of $(A) 1.25$ cubic meters per second (44 cubic feet per second), (B) 9.71 cubic meters per second (343 cubic feet per second), (C) 19.7 cubic meters per second (697 cubic feet per second), and (D) 27.4 cubic meters per second (968 cubic feet per second). 


\section{AllQModeled2.ed.riv - MD_sWMS}

File Vlew Data Grid/Mesh Preprocessing FaSTMECH STORM H2KE Network 1D-Flow Sediment Transpart Habitat Verification Help

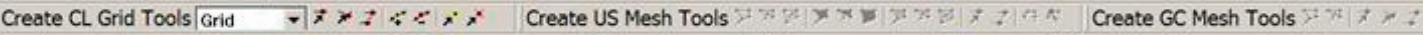

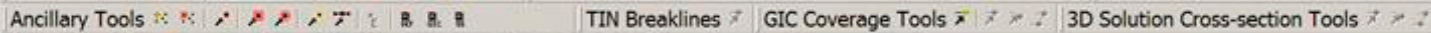

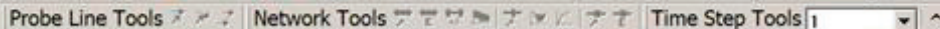

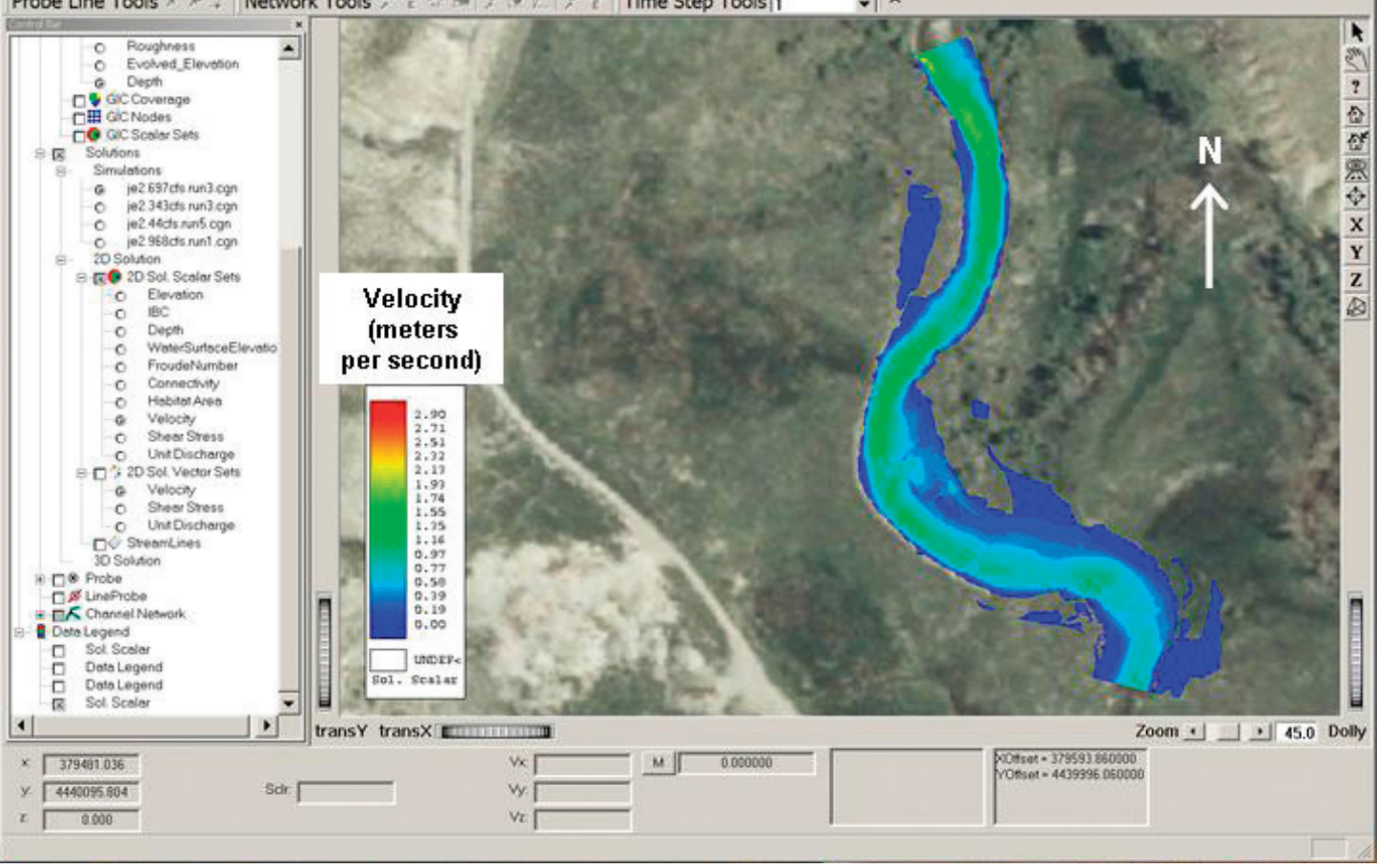

D

AllQModeled2.ed.riv - MD_sWMS

File View Data Grid/Mesh Preprocessing FaSTMECH STORM HZKE Network 1D-Flow Sediment Transport Habitat Verification Help

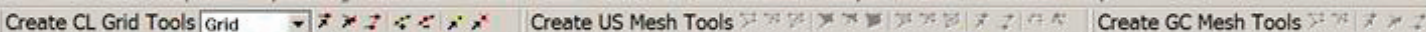

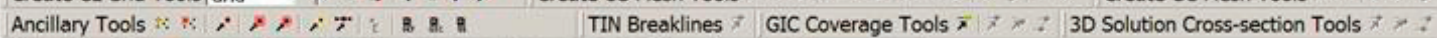

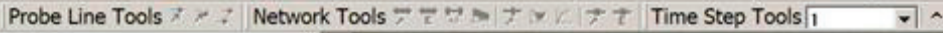

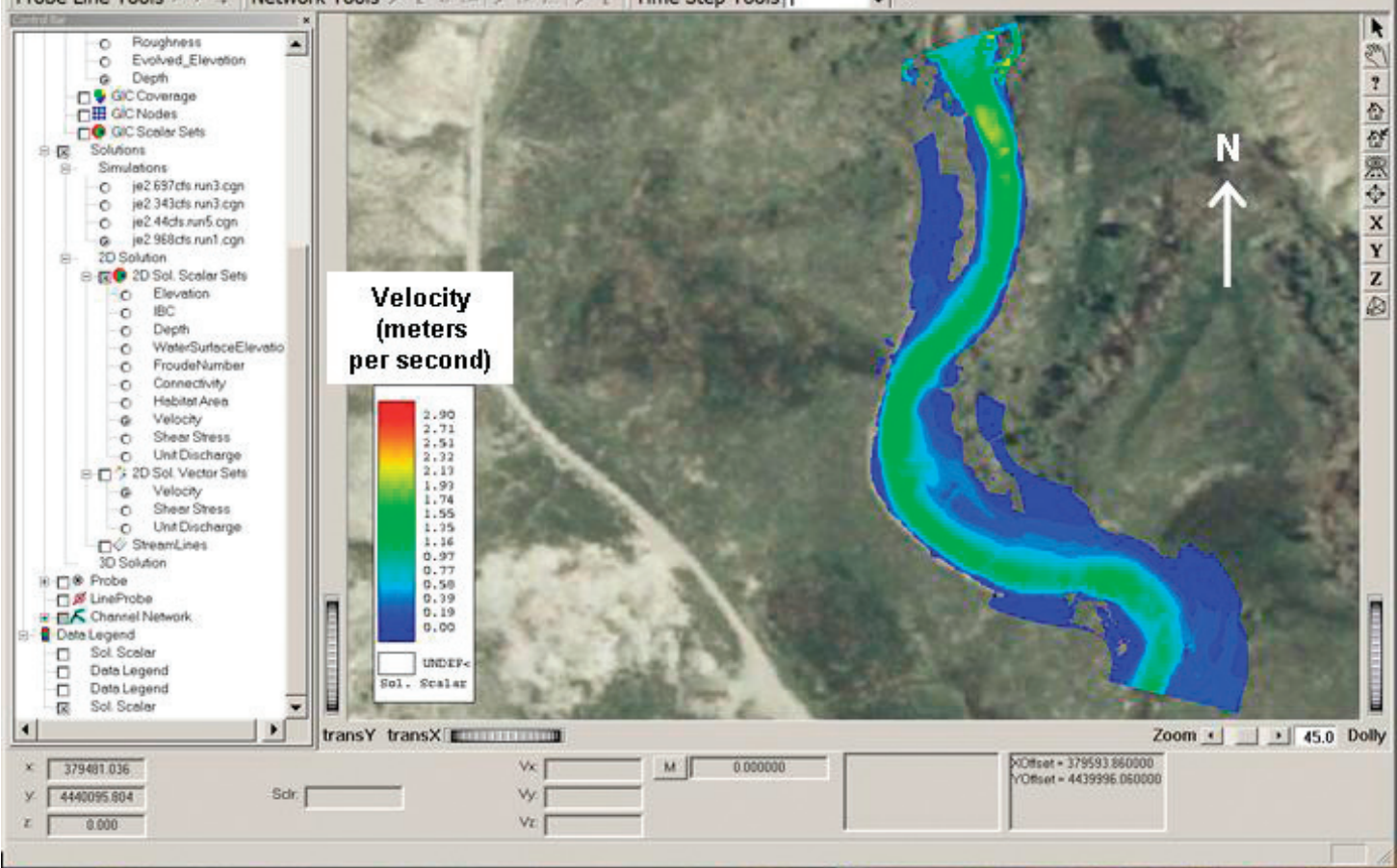

Figure 20 - Continued. Muddy Creek Reach 2 FaSTMECH model solutions for velocity with discharge of (A) 1.25 cubic meters per second (44 cubic feet per second), (B) 9.71 cubic meters per second (343 cubic feet per second), $(C) 19.7$ cubic meters per second (697 cubic feet per second), and $(D) 27.4$ cubic meters per second (968 cubic feet per second). 
A AllQModeled2.ed.riv* - MD sWMS

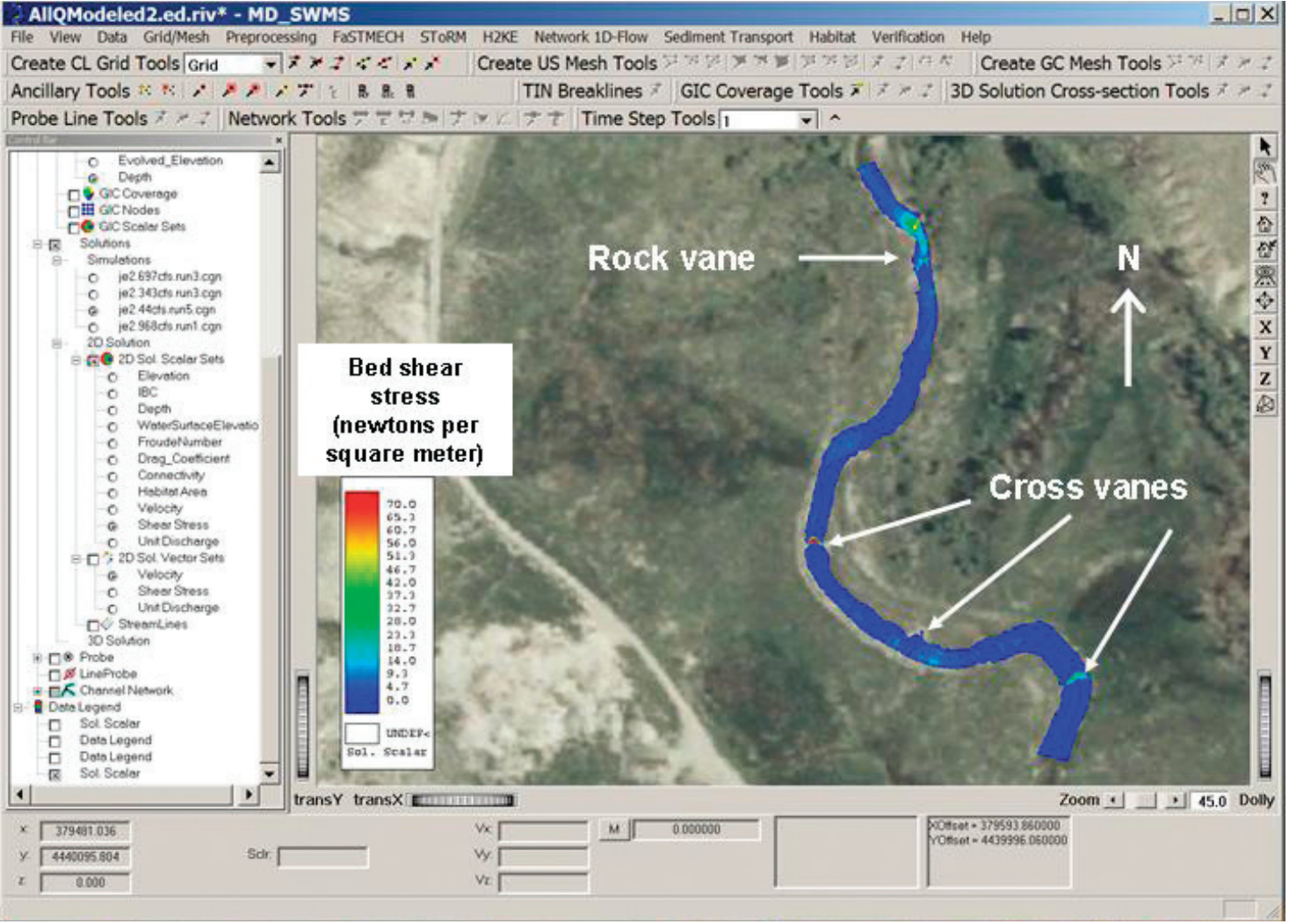

B AllQModeled2.ed.riv - MD_SWMS

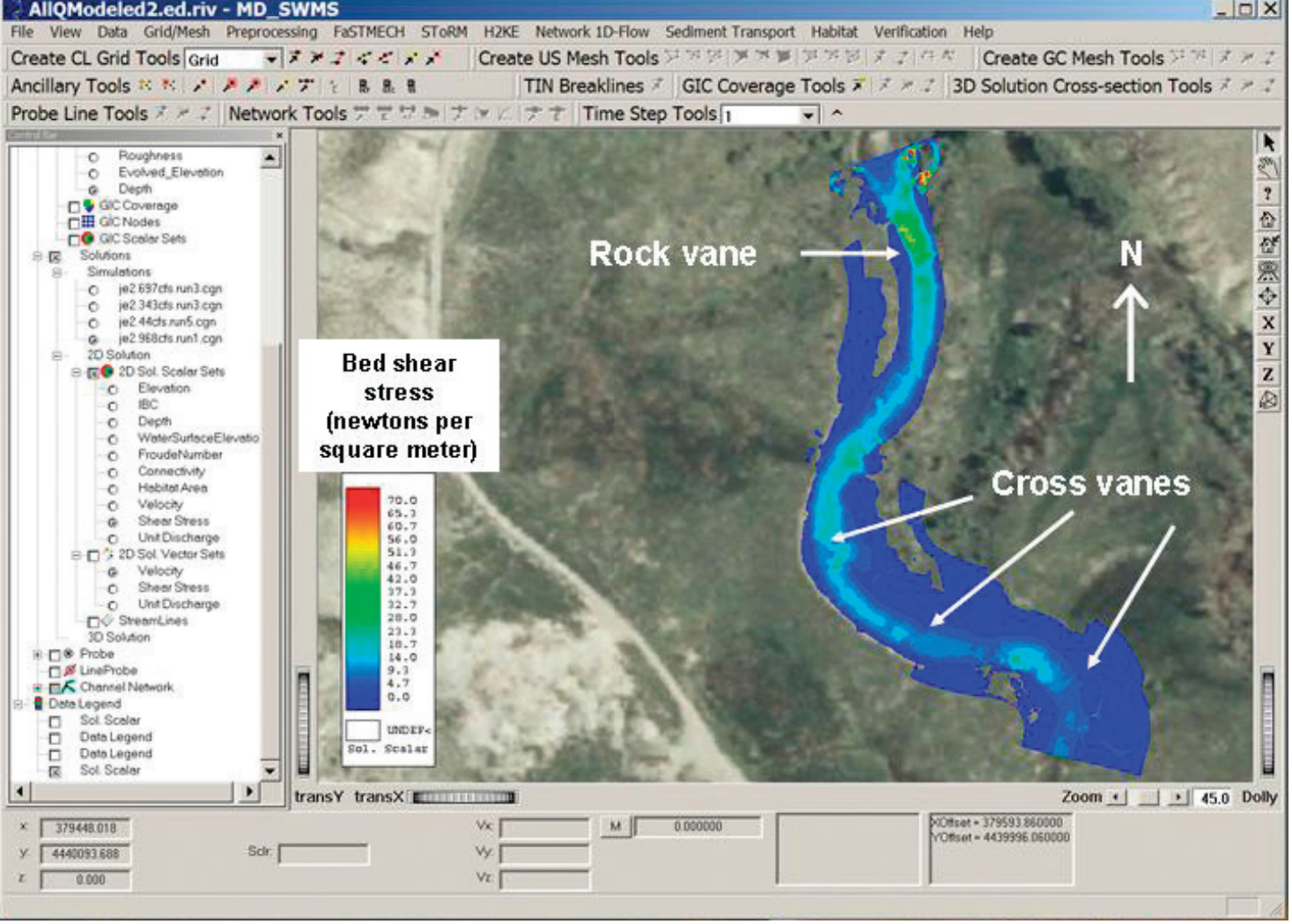

Figure 21. Muddy Creek Reach 2 FaSTMECH model solutions for bed shear stress with discharge of (A) 1.25 cubic meters per second (44 cubic feet per second), (B) 9.71 cubic meters per second (343 cubic feet per second), (C) 19.7 cubic meters per second (697 cubic feet per second), and (D) 27.4 cubic meters per second (968 cubic feet per second). 
C AllQModeled2.ed.riv - MD_sWMS

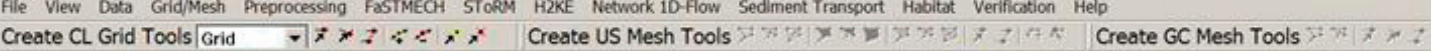

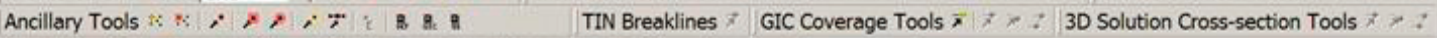

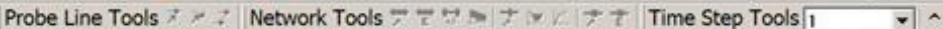

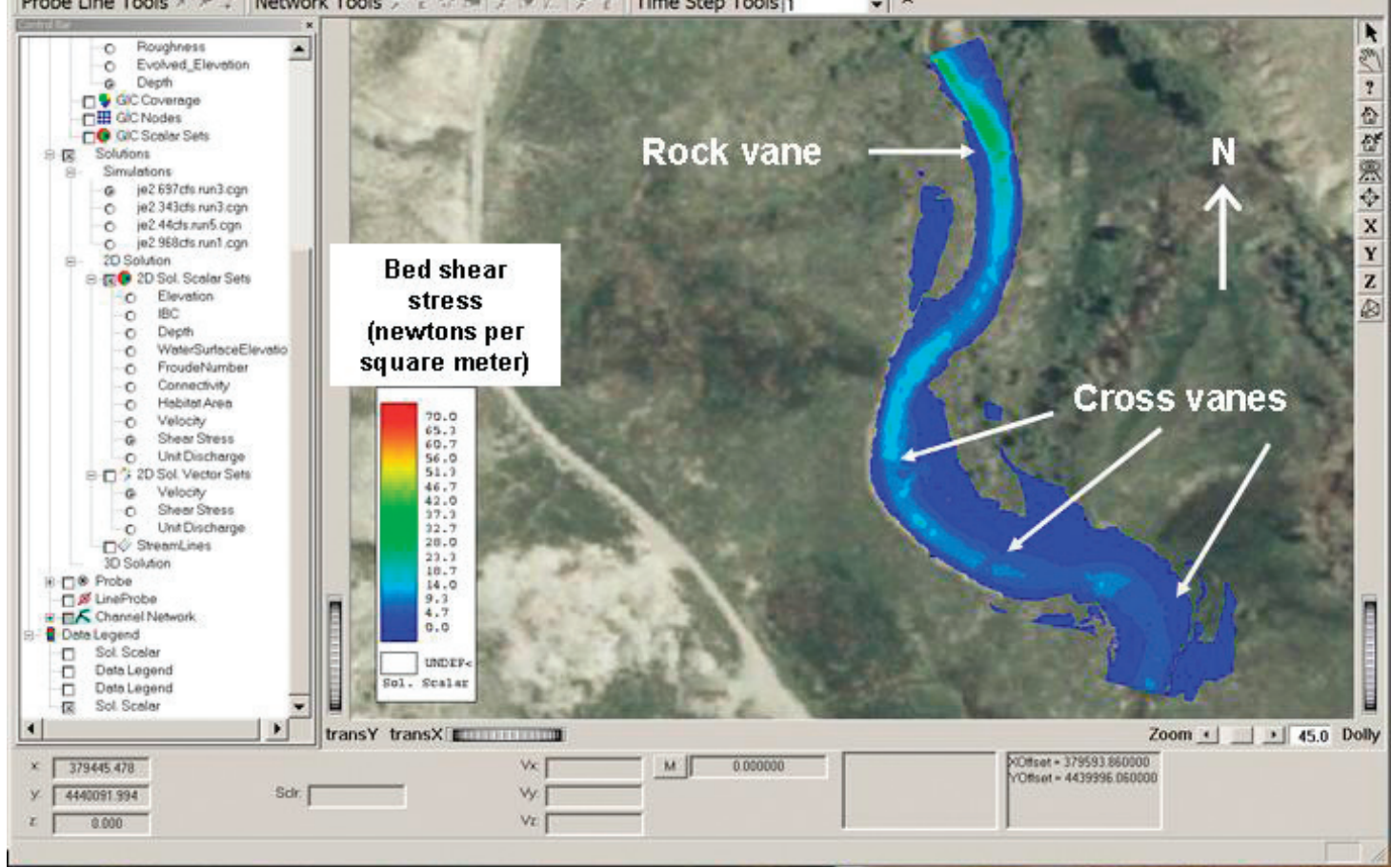

$D$ AllQModeled2.ed.riv - MD_sWMS

File Vlew Data Grid/Mesh Preprocessing FaSTMECH STORM HZKE Network 1D-Flow Sediment Transport Habitat Verification Help

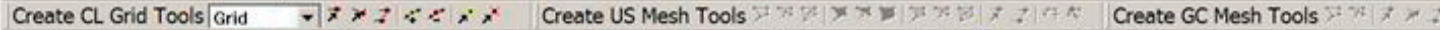

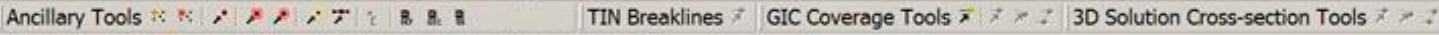

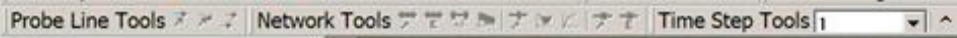

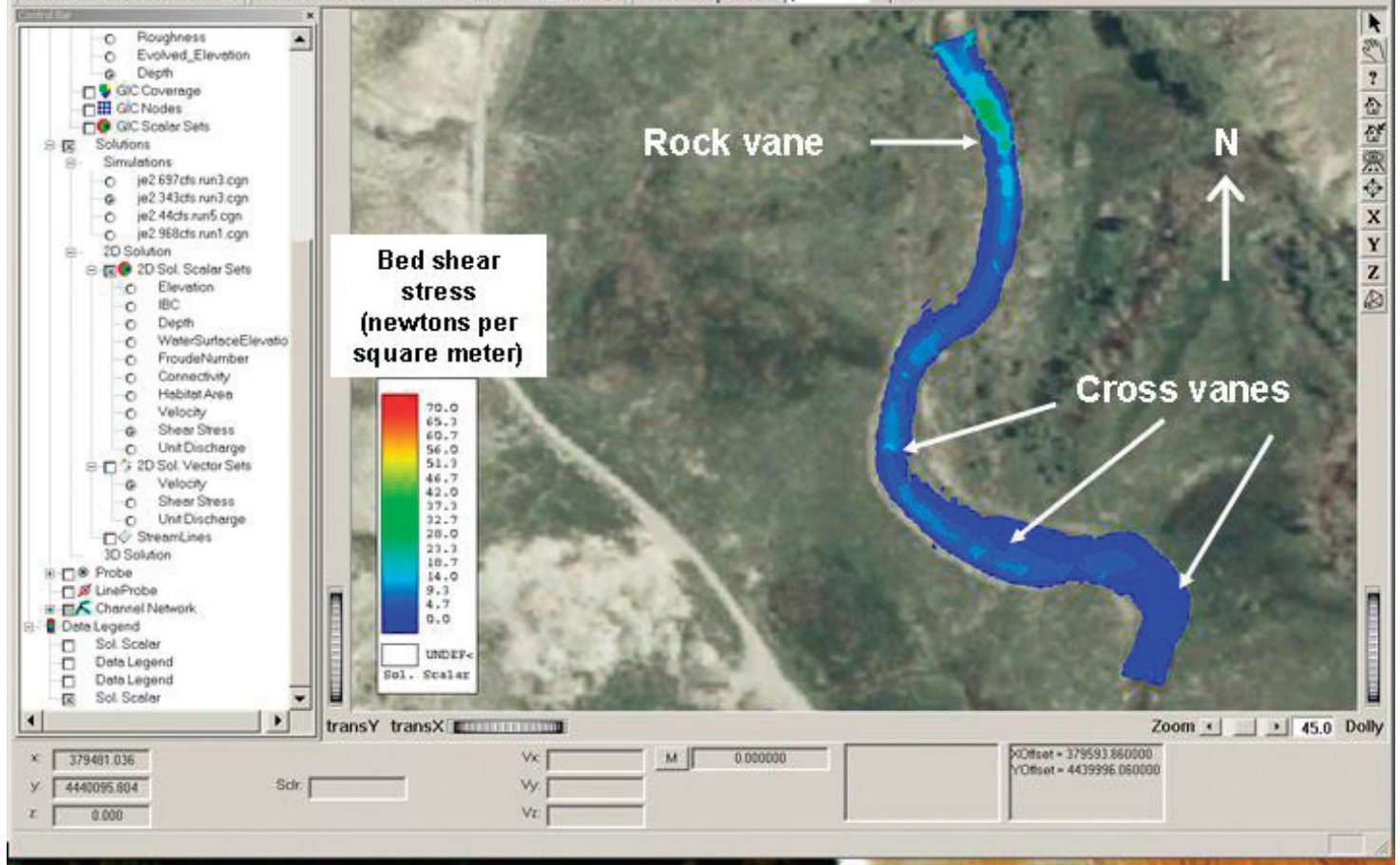

Figure 21-Continued. Muddy Creek Reach 2 FaSTMECH model solutions for bed shear stress with discharge of $(A) 1.25$ cubic meters per second (44 cubic feet per second), (B) 9.71 cubic meters per second (343 cubic feet per second), $(C) 19.7$ cubic meters per second (697 cubic feet per second), and $(D) 27.4$ cubic meters per second (968 cubic feet per second). 
A AllQModeled2.ed.riv* - MD_sWMS

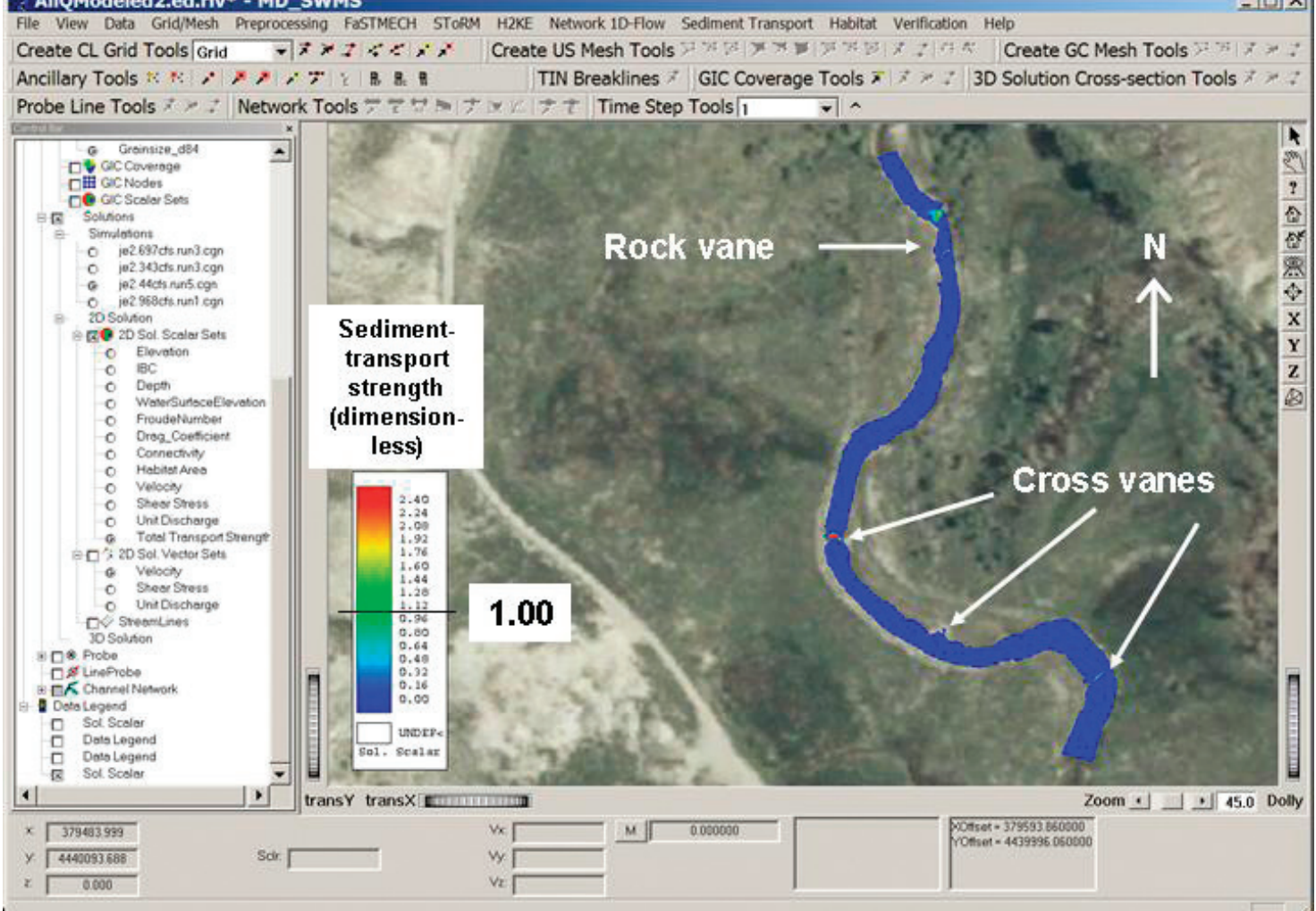

$\boldsymbol{B}$

AllQModeled2.ed.riv - MD_SWMS

File View Data Grid/Mesh Preprocessing FaSTMECH SToRM H2KE Network 10 Flow Sediment Transport Habitat Verification Help

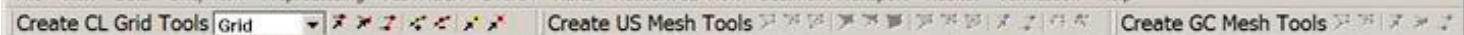

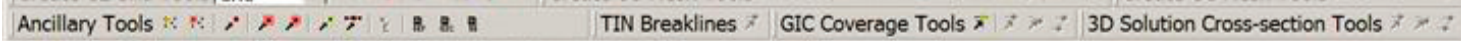

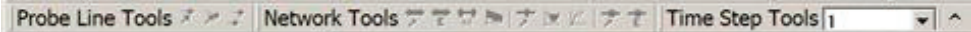

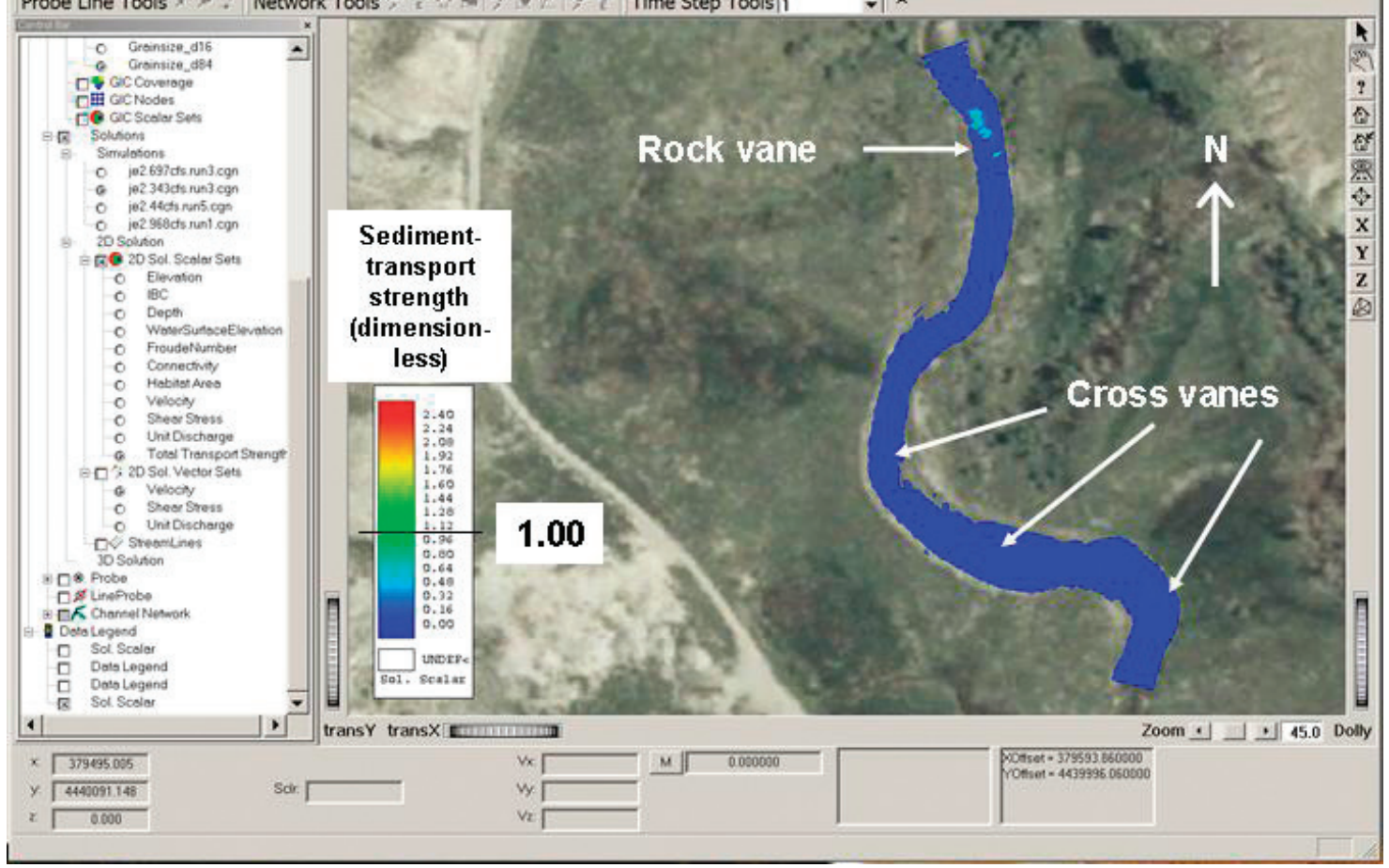

Figure 22. Muddy Creek Reach 2 FaSTMECH model solutions for sediment-transport strength with discharge of $(A) 1.25$ cubic meters per second (44 cubic feet per second), $(B) 9.71$ cubic meters per second (343 cubic feet per second), (C) 19.7 cubic meters per second (697 cubic feet per second), and (D) 27.4 cubic meters per second (968 cubic feet per second). 


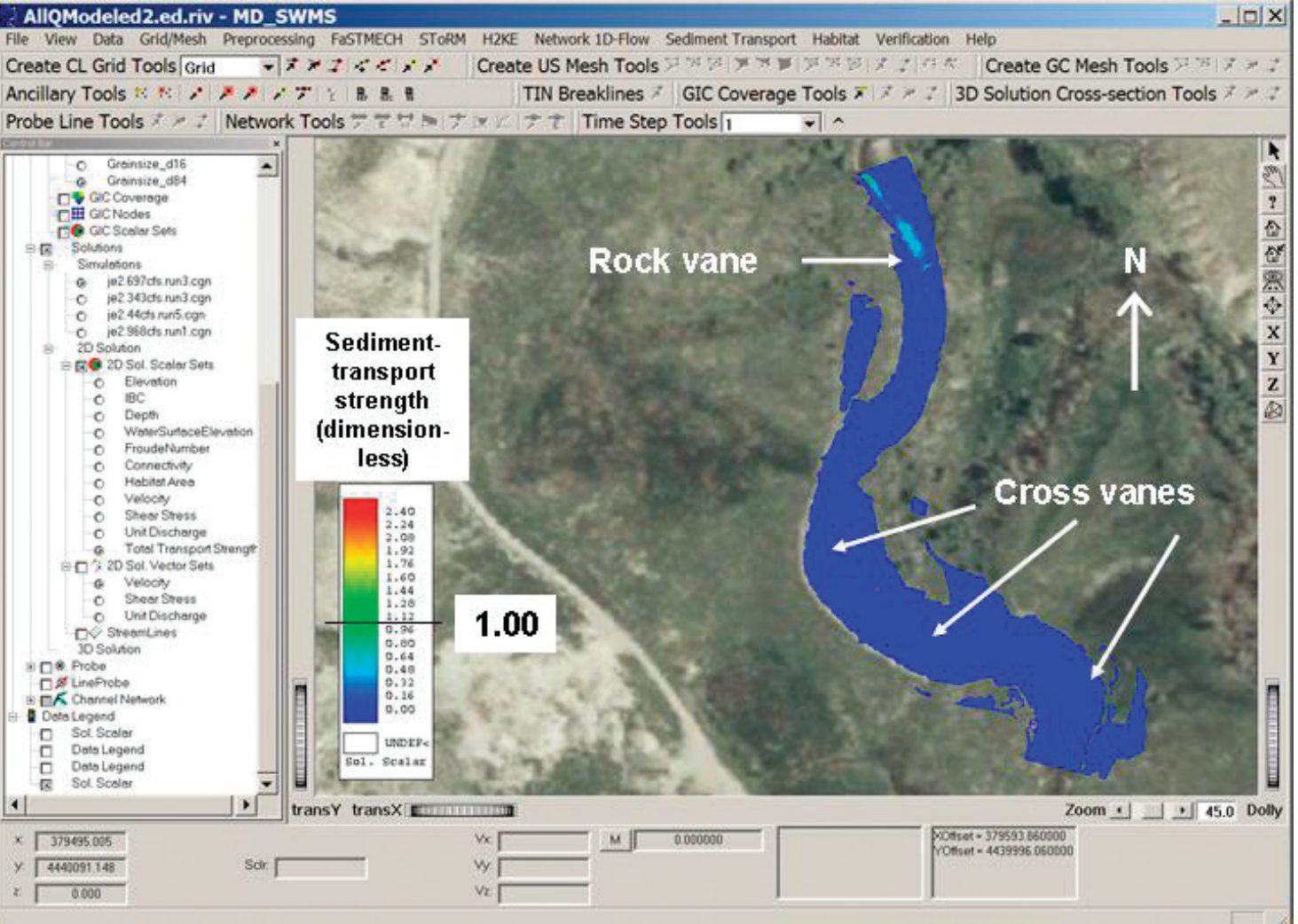

D AllQModeled2.ed.riv - MD SWMS

File View Data Grid/Mesh Preprocessing FaSTMECH STOREM H2KE Network 10 Flow Sediment Transport Habitat Verfication Help

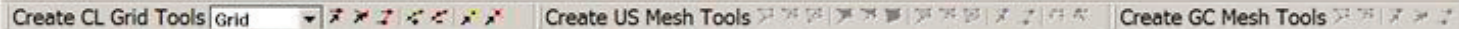

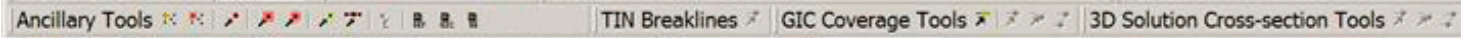

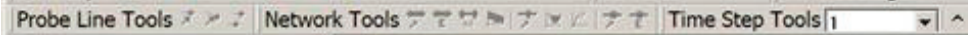

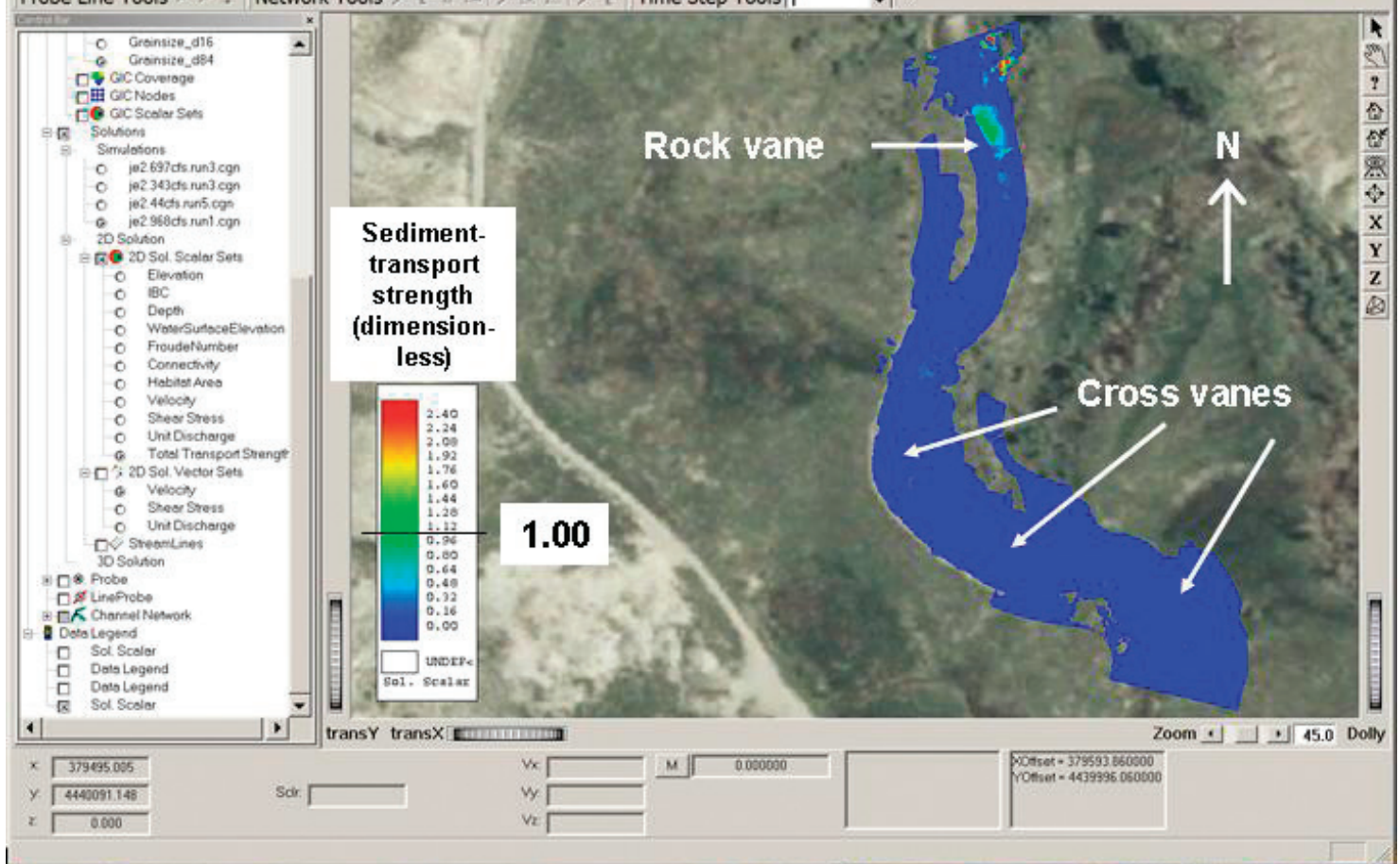

Figure 22 - Continued. Muddy Creek Reach 2 FaSTMECH model solutions for sediment-transport strength with discharge of $(A) 1.25$ cubic meters per second (44 cubic feet per second), (B) 9.71 cubic meters per second (343 cubic feet per second), (C) 19.7 cubic meters per second (697 cubic feet per second), and (D) 27.4 cubic meters per second (968 cubic feet per second). 
$\boldsymbol{A}$

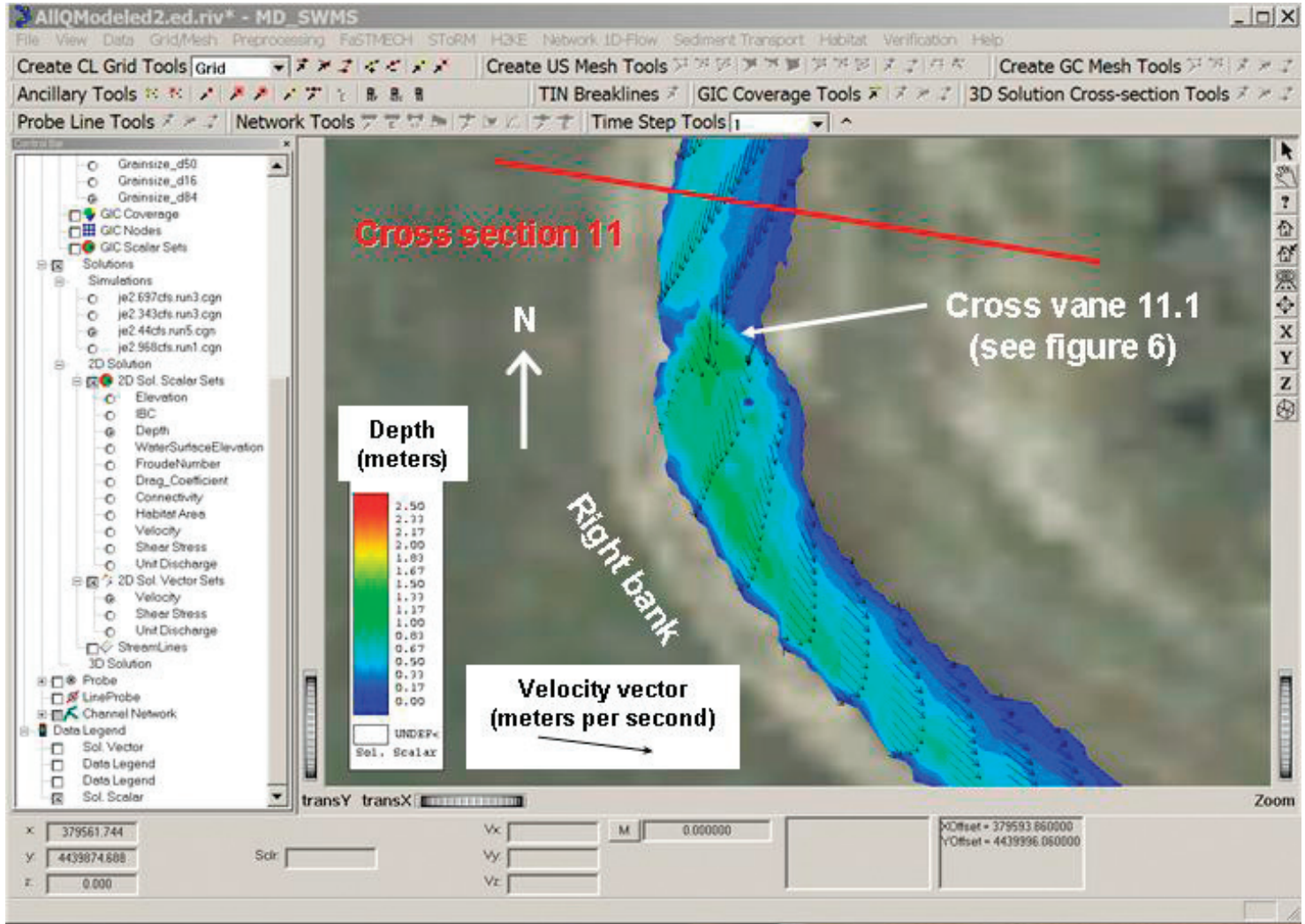

$\boldsymbol{B}$

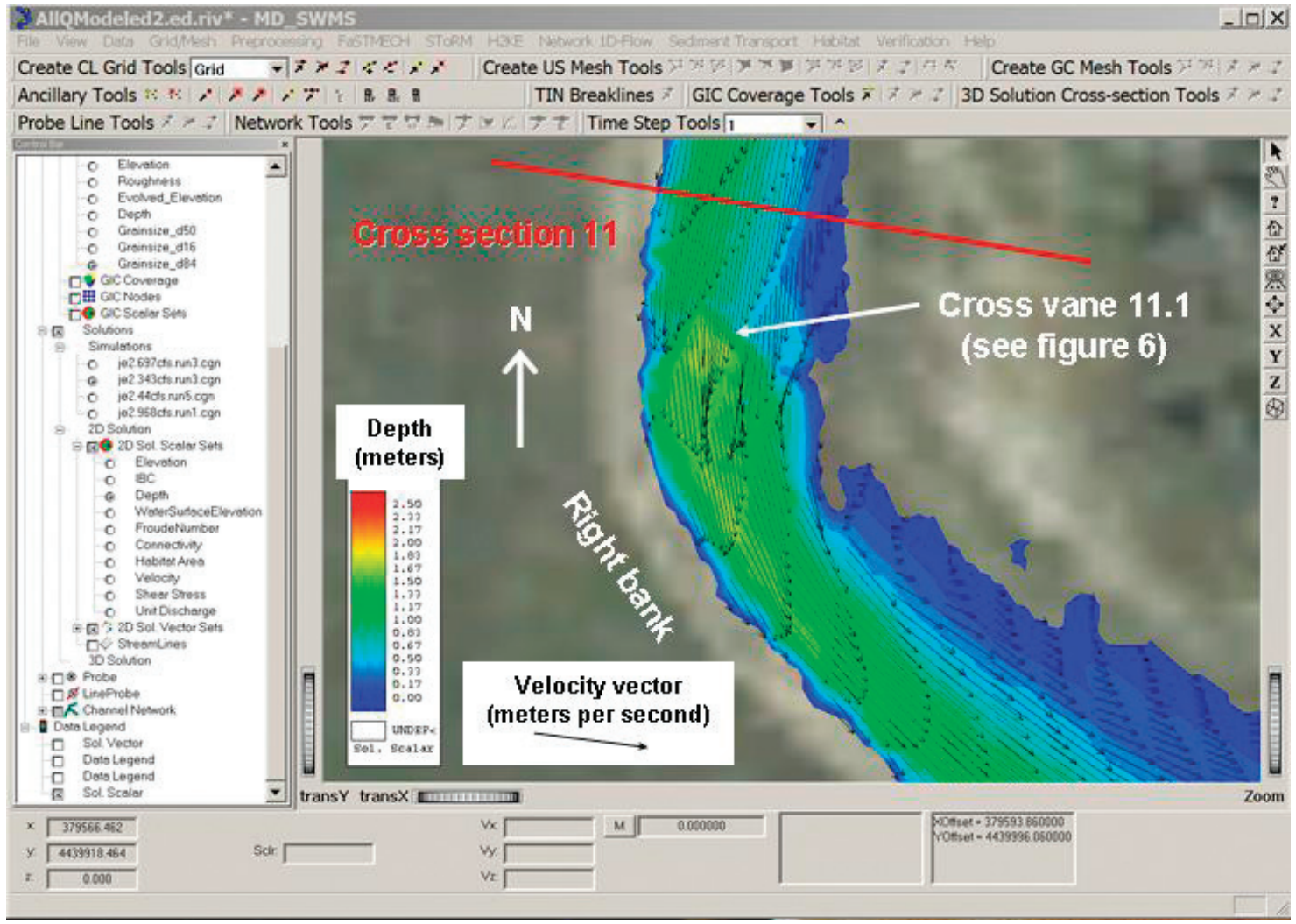

Figure 23. FaSTMECH model solution for Muddy Creek showing depth and velocity vectors at boulder cross vane near cross section 11 with discharge of $(A) 1.25$ cubic meters per second (44 cubic feet per second), (B) 9.71 cubic meters per second (343 cubic feet per second), (C) 19.7 cubic meters per second (697 cubic feet per second), and (D) 27.4 cubic meters per second (968 cubic feet per second). 


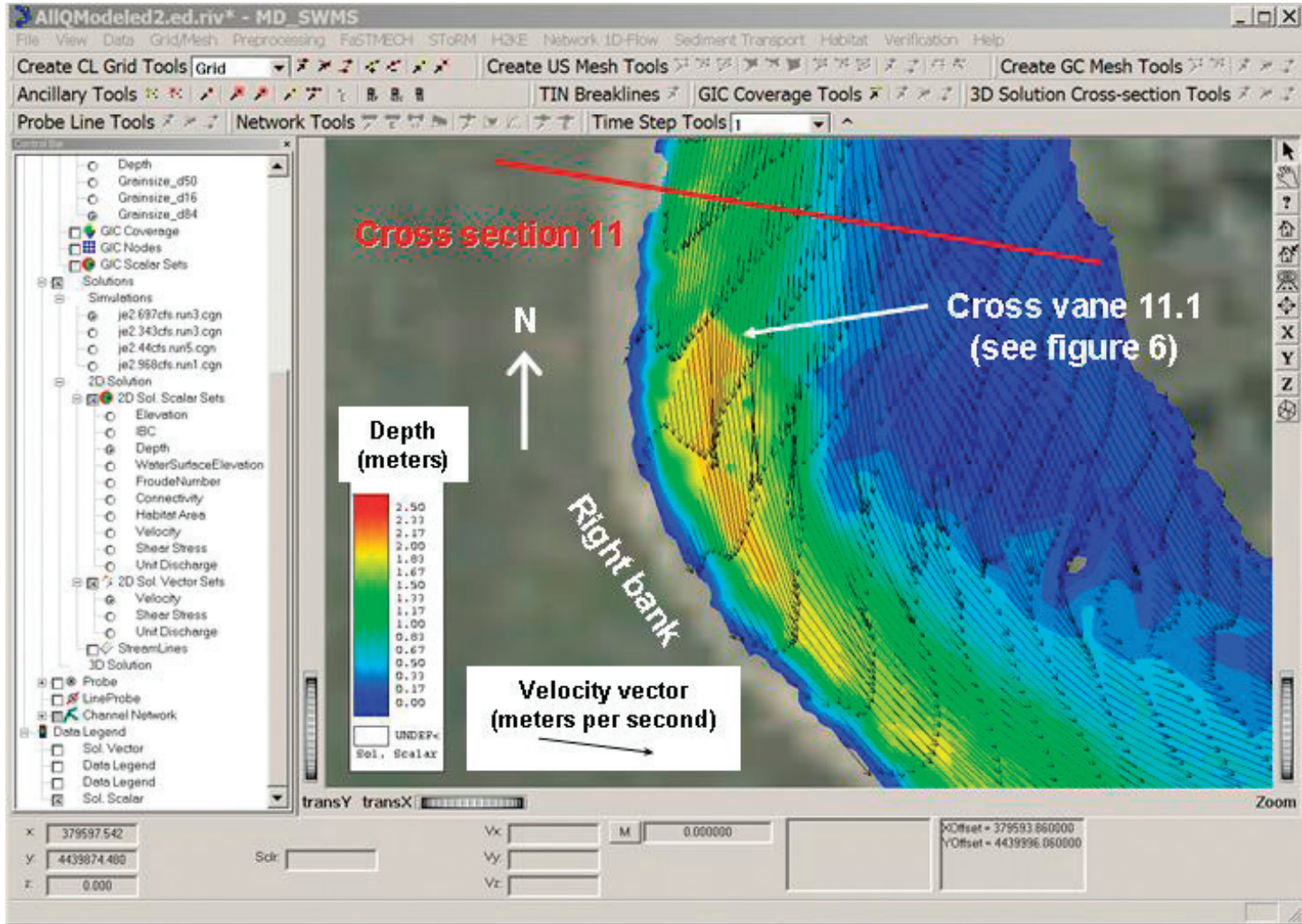

D

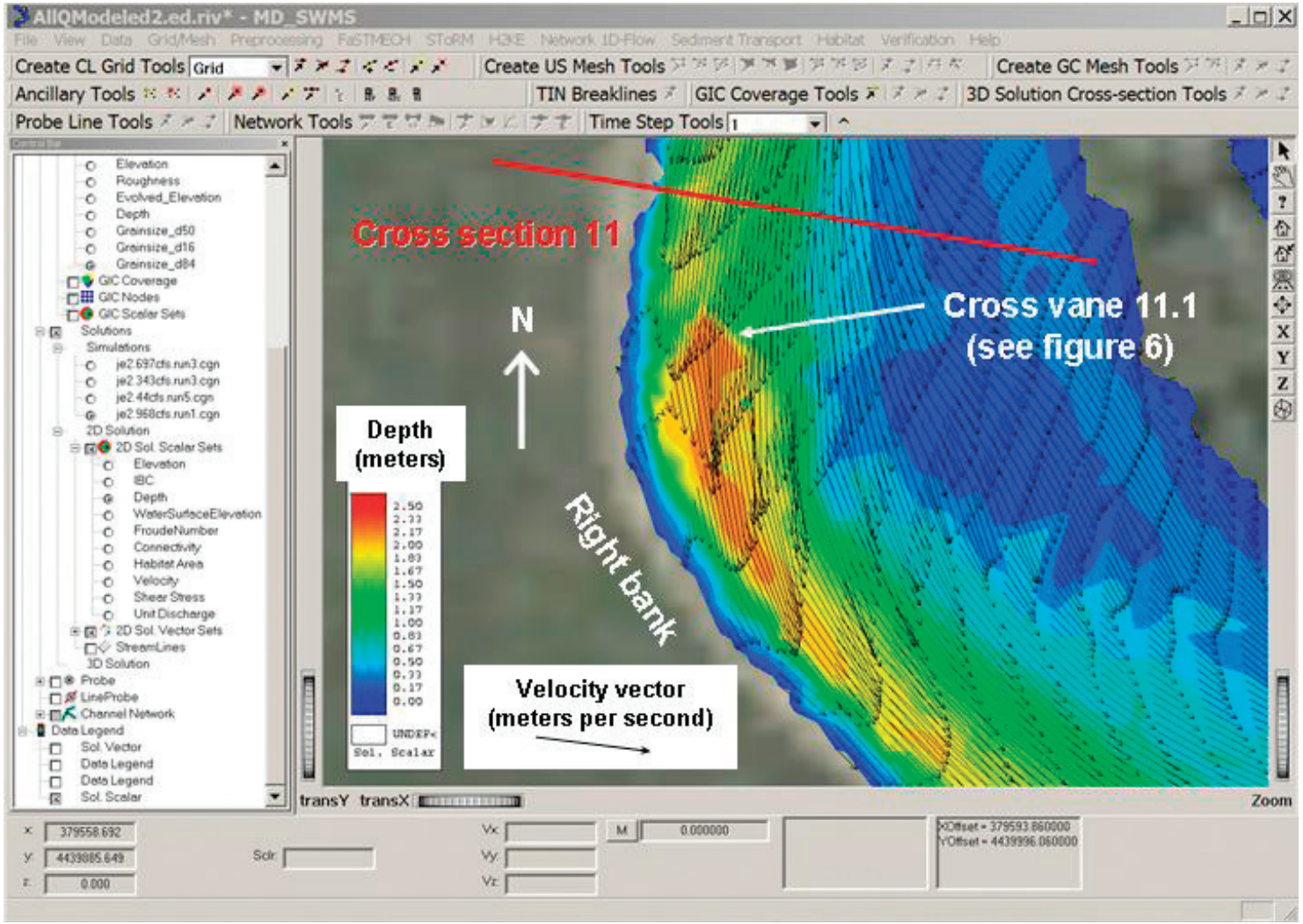

Figure 23 - Continued. FaSTMECH model solution for Muddy Creek showing depth and velocity vectors at boulder cross vane near cross section 11 with discharge of $(A) 1.25$ cubic meters per second (44 cubic feet per second), (B) 9.71 cubic meters per second (343 cubic feet per second), (C) 19.7 cubic meters per second (697 cubic feet per second), and (D) 27.4 cubic meters per second (968 cubic feet per second). 


\section{Summary}

Muddy Creek near Kremmling, Colorado, is a regulated, meandering, gravel-bed stream where selected "natural-channel design" methods were used in 2003 in an attempt to stabilize a short reach of the channel and enhance aquatic habitat. This reconfigured reach (reach 2) and an upstream control reach where no channel modifications were performed (reach 1) were analyzed during 2001-2008 as part of the USGS Reconfigured Channel Monitoring and Assessment Program (RCMAP).

The Muddy Creek monitoring program was conducted by the U.S. Geological Survey from 2001 to 2008, in cooperation with the Colorado River Water Conservation District, and the streamflow modeling and analysis were conducted in 2008 in cooperation with the Colorado River Water Conservation District and the Colorado Water Conservation Board.

The goals of the Muddy Creek study were to (1) monitor and quantify geomorphic changes in Muddy Creek related to controlled streamflow releases from an upstream reservoir, (2) compare geomorphic changes in a reach that was reconfigured using the natural-channel design approach (reach 2) with changes in an unaltered control reach (reach 1), and (3) simulate hydraulic conditions in both reaches for a range of discharges and examine the function of natural-channel design boulder structures in a meandering gravel-bed stream. The purpose of this report is to describe geomorphic characteristics, simulations of hydraulic conditions, and potential for geomorphic changes in the unaltered (control) reach and nearby reconfigured reach of Muddy Creek.

Streamflow in Muddy Creek has been regulated by Wolford Mountain Reservoir since 1995. Annual peak discharges ranged from 217 to $968 \mathrm{ft}^{3} / \mathrm{s}$ during the monitoring period. A reference bankfull discharge was not determined for the monitoring reaches because the flow is regulated; however, the annual flood peaks in $2006\left(917 \mathrm{ft}^{3} / \mathrm{s}\right)$ and $2008\left(968 \mathrm{ft}^{3} / \mathrm{s}\right)$ were well above relict bank and point-bar surfaces that likely were established before 1995 .

Reconfiguration activities in 2003 that altered the channel in reach 2 included excavating and lowering the streambed in some locations, constructing flow-directing "cross-vanes," "rock vanes," and boulder clusters in several places, installing boulder riprap and log crib work along the concave streambanks of some meander bends, and decreasing the banks from nearly vertical to a lesser angle by regrading. The channel pattern (sinuosity, meander radius of curvature, meander wavelength, and channel alignment) was not altered.

Standard geomorphic methods were used to quantify and monitor channel cross-section and sediment-size characteristics periodically, and these measurements were augmented with oblique photography from monumented locations. Minor changes in channel geometry at monitored cross sections were measured between 2001 and 2008 in the control reach and between 2003 and 2008 in the reconfigured reach. Exceptions to this observation included approximately $2.5 \mathrm{~m}$ of lateral erosion in a meander bend at cross section 6 and lateral erosion of an alluvial fan forming a vertical scarp between cross sections 4 and 5 in the control reach. Also, some streambed locations in reach 2, excavated during reconfiguration, have aggraded to their former elevations, and alluvial-bar gravel might have become better sorted and winnowed of sand-size sediment. Replicate cross-section plots, sediment-size distribution plots, and photographs from the Muddy Creek study area can be viewed on the RCMAP Web site: http://co.water.usgs.gov/ projects/rcmap/MuddyCreek/indexmuddycreek.html (accessed April 28, 2010). Water-surface elevations were surveyed for multiple discharges in 2008, including the annual peak. Corresponding discharges were determined from a nearby USGS streamflow-gaging station (09041400 Muddy Creek below Wolford Mountain Reservoir near Kremmling, Colorado) and from rating curves developed with acoustic Doppler current profiler (ADCP) and acoustic Doppler velocity meter (ADVM) measurements in reaches 1 and 2 .

Multidimensional streamflow modeling was used to evaluate the hydraulic conditions of Muddy Creek in reaches 1 and 2 and to provide insight to geomorphic changes observed since 2001. Application of the USGS MD_SWMS framework and FaSTMECH computational models to Muddy Creek also provided an opportunity to gain insight and understanding of the hydraulic conditions in a previously unsimulated fluvial setting, that of a reconfigured channel fitted with flow-directing boulder structures commonly used in the "natural-channel design" approach.

The computational streamflow models were calibrated with surveyed water-surface elevations and the corresponding discharges measured in the two modeled reaches for low, medium, high, and out-of-bank discharges. Discharge simulations produced 2-dimensional solutions for flow depth, velocity, bed shear stress, and sediment-transport strength. Modeled areas of high bed shear stress in each discharge simulation generally occurred in areas of the greatest depth and velocity, such as in meander bends (where depths were greater) and in steeper gradient areas (where velocities were greater).

The transport strength solution represented the potential for sediment entrainment and transport but did not simulate the cumulative effects of streambed evolution over time. Simulated sediment transport strength indicated that widespread entrainment of the streambed median particle size likely will occur only in isolated subreaches at discharges slightly above bankfull conditions in reaches 1 and 2. Finer grained, alternate bar gravels at cross sections 10 and 12, are mobilized by lesser discharges than those needed to mobilize the coarser gravels and cobbles that compose the streambed elsewhere. Onsite observations after the 2008 peak discharge generally supported model simulations indicating sediment mobility in small areas predominantly at high and out-ofbank discharges. The small areas of potential streambed mobility identified by model simulations indicate that the Muddy Creek channel in reaches 1 and 2 is relatively stable at discharges up to and slightly greater than the approximate "bankfull" discharge.

Boulder cross vanes of the type used in "natural-channel design" reconfiguration projects redirected and concentrated discharge at all simulated discharges and created locally high shearstress areas in reach 2. However, the boulder structures' contribution to channel stability in reach 2 could not be determined from the available data. The minor channel geomorphic changes from 
2001 to 2008 in reach 2 were comparable to the minor changes in reach 1 during the same time period, indicating that these boulder structures might not have been necessary to maintain the channel pattern and position of Muddy Creek in reach 2.

\section{Acknowledgments}

Many individuals assisted with data collection over several years, including Stephen J. Char, George P. Ingersoll, Paul J. Kinzel, Michael S. McCurdy, and Barbara C. Ruddy, of the USGS, and Stevan Gyetvai, Ashley K. Heckman, and Gregory B. O'Neill, formerly of the USGS. Additional onsite assistance was provided by Lorena Davis of the University of Colorado, Jeff McPherson of the U.S. Environmental Protection Agency, and Ray D. Tenney, Colorado River Water Conservation District. A preconstruction survey of Muddy Creek was performed by David Costner, Mathew Wentz, and Arianne Venzon of Geosurve, Inc., Lafayette, Colorado.

The authors thank Wolford Mountain Reservoir operators, Kem Davidson and Don Meyer, who coordinated reservoir releases to facilitate geomorphic surveys and sediment measurements in Muddy Creek downstream from the reservoir, and Kelley Taussig of the Grand River Ranch, who granted access to monitored sites in the reconfigured reach of Muddy Creek. The quality of the manuscript has been greatly enhanced by technical review comments from Charles E. Berenbrock and Brandy L. Logan, USGS, and by Robert E. Davis, USGS, retired. All photographs were taken by John G. Elliott, USGS.

\section{References Cited}

Andrews, E.D., 1983, Entrainment of gravel from naturally sorted riverbed material: Geological Society of America Bulletin, v. 94, p. 1225-1231.

Barton, G.J., McDonald, R.R., Nelson, J.M., and Dinehart, R.L., 2005, Simulation of flow and sediment mobility using a multidimensional flow model for the white sturgeon critical-habitat reach, Kootenai River near Bonners Ferry, Idaho: U.S. Geological Survey Scientific Investigations Report 2005-5230, 54 p.

Benson, M.A., and Dalrymple, Tate, 1967, General field and office procedures for indirect discharge measurements: Techniques of Water-Resources Investigations of the U.S. Geological Survey, book 3, chap. A1, 30 p.

Berenbrock, C., and Tranmer, A.W., 2008, Simulation of flow, sediment transport, and sediment mobility of the Lower Coeur d'Alene River, Idaho: U.S. Geological Survey Scientific Investigations Report 2008-5093, 52 p.
Butler, David, 1990, Estimated water-quality conditions and potential downstream channel effects of the proposed Rock Creek and Wolford Mountain Reservoirs, north-central Colorado: U.S. Geological Survey Water-Resources Investigations Report 89-4177, $101 \mathrm{p}$.

Carling, P.A., 1983, Threshold of coarse sediment transport in broad and narrow natural streams: Earth Surface Processes, v. 8 , p. 1-18.

Dunne, T., and Leopold, L.B., 1978, Water in environmental planning: San Francisco, W.H. Freeman and Co., 818 p.

Elliott, J.G., and Capesius, J.P., 2009, Geomorphic changes resulting from floods in reconfigured river channels in Colorado, USA, in James, L.A., Rathburn, S.L., and Whittecar, G.R., eds., Management and restoration of fluvial systems with broad historical changes and human impacts: Geological Society of America Special Paper 451, p. 173-198.

Elliott, J.G., and Hammack, L.A., 1999, Geomorphic and sedimentologic characteristics of alluvial reaches in the Black Canyon of the Gunnison National Monument, Colorado: U.S. Geological Survey Water-Resources Investigations Report 99-4082, 67 p.

Elliott, J.G., and Hammack, L.A., 2000, Entrainment of riparian gravel and cobbles in an alluvial reach of a regulated canyon river: Regulated Rivers-Research and Management, v. 16 , no. 1 , p. $37-50$.

Elliott, J.G., and Parker, R.S., 1999, Reconfigured-channel monitoring and assessment program: U.S. Geological Survey Water-Resources Investigations Report 99-4111, 6 p.

Emmett, W.W., and Hadley, R.F., 1968, The Vigil NetworkPreservation and access of data: U.S. Geological Survey Circular 460-C, $21 \mathrm{p}$.

Fahnestock, R.K., 1963, Morphology and hydrology of a glacial stream-White River, Mount Rainier, Washington: U.S. Geological Survey Professional Paper 442-A, p. 1-70.

Federal Interagency Stream Restoration Working Group, 2001, Stream corridor restoration-Principles, processes, and practices: Washington, D.C,. Government Printing Office, variously paginated.

Fitzpatrick, F.A., Waite, I.R., D’Arconte, P.J., Meador, M.R., Maupin, M.A., and Gurtz, M.E., 1998, Revised methods for characterizing stream habitat in the National Water-Quality Assessment Program: U.S. Geological Survey WaterResources Investigations Report 98-4052, 67 p.

Gotvald, A.J., and Oberg, K.A., 2008, Acoustic Doppler current profiler applications used in rivers and estuaries by the U.S. Geological Survey: U.S. Geological Survey Fact Sheet 2008-3096, 4 p.

Harrelson, C.C., Rawlins, C.L, and Potyondy, J.P., 1994, Stream channel reference sites-An illustrated guide to field technique: U.S. Department of Agriculture, Forest Service General Technical Report RM-245, 61 p. 
Hickman, T., and Raleigh, R.F., 1982, Habitat suitability index models - Cutthroat trout: U.S. Fish and Wildlife Service Biology Report 82(10.5), 38 p.

Juracek, K.E., and Fitzpatrick, F.A., 2003, Limitations and implications of stream classification: Journal of the American Water Resources Association, v. 39, no. 3, June 2003, p. 659-670.

Kenney, T.A., 2005, Initial-phase investigation of multidimensional streamflow simulations in the Colorado River, Moab valley, Grand County, Utah, 2004: U.S. Geological Survey Scientific Investigations Report 2005-5022, 69 p.

Kochel, R.C., Miller, J.R., Lord, M., and Martin, T., 2005, Geomorphic problems with in-stream structures using natural channel design strategy for stream restoration projects in North Carolina: Geological Society of America Abstracts with Programs, v. 37, no. 7, p. 329.

Komar, P.D., 1987, Selective gravel entrainment and the empirical evaluation of flow competence: Sedimentology, v. 34 , p. $1165-1176$.

Kondolf, G.M., 1998, Lessons learned from river restoration projects in California: Aquatic Conservation-Marine and Freshwater Ecosystems, v. 8, p. 39-52.

Kondolf, G.M., and Micheli, E.R., 1995, Evaluating stream restoration projects: New York, Springer-Verlag, Environmental Management, v. 19, no. 1, p. 1-15.

Lane, E.W., 1955, Design of stable channels: Transactions, American Society of Civil Engineers, v. 120, no. 2776, p. 1234-1279.

Lisle, T.E., Iseya, F., and Ikeda, H., 1993, Response of a channel with alternate bars to a decrease in supply of mixed-size bed load-A flume experiment: Water Resources Research, v. 29 , no. 11 , p. 3623-3629.

McDonald, R.R., Nelson, J.M., and Bennett, J.P., 2005a, Multidimensional surface-water modeling system user's guide: U.S. Geological Survey Techniques and Methods 6-B2, 136 p.

McDonald, R.R., Nelson, J.M., Kinzel, P.J., and Conway, J.S., 2005b, Modeling surface-water flow and sediment mobility with the Multi-Dimensional Surface-Water Modeling System (MD_SWMS): U.S. Geological Survey Fact Sheet 2005-3078, 6 p. (online fact sheet) http://pubs.usgs.gov/ $f_{S} / 2005 / 3078 /$ (accessed June 29, 2009).

Meyer-Peter, E., and Muller, R., 1948, Formulas for bedload transport: Proceedings of the International Association of Hydraulic Research, 2d Meeting, Stockholm, 1948, p. 39-64.

Miall, A.D., 1985, Architectural-element analysis-A new method of facies analysis applied to fluvial deposits: EarthScience Reviews, v. 22, no. 4, p. 261-308.
Milhous, R.T., 1982, Effect of sediment transport and flow regulation on the ecology of gravel-bed rivers, in Hey, R.D., Bathhurst, J.C., and Thorne, C.R., eds., Gravel-bed rivers: Chichester, England, John Wiley and Sons, Limited, p. 819-842.

Montgomery, D.R., and Buffington, J.M., 1993, Channel classification, prediction of channel response, and assessment of channel condition: Report TFW-SH10-93-002 prepared for the SHAMW committee of the Washington State Timber/ Fish/Wildlife Agreement, 84 pages plus figures.

Mosley, M.P., 1982, A procedure for characterising river channels: Christchurch Water and Soil Science Centre, Ministry of Works and Development, Christchurch, New Zealand, Water and Soil Miscellaneous Publications no. 32, 67 p.

Neill, C.R., 1968, A re-examination of the beginning of movement for coarse granular bed materials: Wallingford, United Kingdom, Hydraulics Research Station, report no. INT 68, $37 \mathrm{p}$.

Nelson, J.M., Bennett, J.P., and Wiele, S.M., 2003, Flow and sediment-transport modeling, in Kondolf, G.M., and Piegay, H., eds., Tools in fluvial geomorphology: Chichester, England, Wiley and Sons, p. 539-576.

Osterkamp, W.R., 2008, Annotated definitions of selected geomorphic terms and related terms of hydrology, sedimentology, soil science and ecology: U.S. Geological Survey Open-File Report 2008-1217, 49 p.

Parker, Gary, Klingman, P.C., and McLean, D.G., 1982, Bedload and size distribution in paved gravel-bed streams: American Society of Civil Engineers, Journal of the Hydraulics Division 108(HY4), p. 544-571.

Parker, Gary, Toro-Escobar, C.M., Ramey, Michael, and Beck, Stewart, 2003, Effect of floodwater extraction on mountain stream morphology: American Society of Civil Engineers, Journal of Hydraulic Engineering, v. 129, no. 11, p. 885-889.

Powell, D.M., and Ashworth, P.J., 1995, Spatial pattern of flow competence and bed load transport in a divided gravel bed river: Water Resources Research, v. 31, no. 3, p. 741-752.

Raleigh, R.F., Zuckerman, L.D., and Nelson, P.C., 1986, Habitat suitability index models and instream flow suitability curves - Brown trout, revised: U.S. Fish Wildlife Service Biology Report 82 (10.124), 65 p.

Rosgen, D.L., 1996, Applied river morphology: Pagosa Springs, Colorado, Wildland Hydrology, various pagination.

Rosgen, D.L., 2001, The cross-vane, W-weir and J-hook vane structures - Their description, design and application for stream stabilization and river restoration: American Association of Civil Engineers, Proceedings, Reno, Nevada, 22 p.

Rosgen, D.L., 2006, River restoration using a geomorphic approach for natural channel design, in Proceedings of the Eighth Federal Interagency Sedimentation Conference, vol. 1: Subcommittee on Sedimentation, Reno, Nevada, p. 394-401. 
Rosgen, D.L., 2007, Rosgen geomorphic channel design, in Bernard, J., Fripp, J.F., and Robinson, K.R., eds., Part 654 Stream Restoration Design National Engineering Handbook (210-VI-NEH), Chapter 11: U.S. Department of Agriculture Natural Resources Conservation Service, Washington, D.C.

Ruddy, B.C., 1987, Sediment discharge in Muddy Creek and the effect of sedimentation rate on the proposed Wolford Mountain Reservoir near Kremmling, Colorado: U.S. Geological Survey Water-Resources Investigations Report 87-4011, 22 p.

Shields, A., 1936, Application of similarity principles and turbulence research to bedload movement, translated from Anwendung der Aehnlichkeitsmechanik und der Turbulenzforschung auf die Geschiebewegung: Mitteilung Preussischen Versuchanstalt fur Wasserbau und Schiffbau, Berlin, no. 26, by Ott, W.P., and van Uchelen, J.C.: Pasadena, California, California Institute of Technology Hydrodynamics, report no. 167,43 p.

Simon, A., Doyle, M., Kondolf, M., Shields, F.D., Jr., Rhodes, B., and McPhillips, M., 2007, Critical evaluation of how the Rosgen classification and associated "natural channel design" methods fail to integrate and quantify fluvial processes and channel response: Journal of the American Water Resources Association, v. 43, no. 5, p. 1117-1131.

Simpson, M.R., 2001, Discharge measurements using a broadband acoustic Doppler current profiler: U.S. Geological Survey Open-File Report 2001-1, 134 p.

Smelser, M.G., and Schmidt, J.C., 1998, An assessment methodology for determining historical changes in mountain streams: U.S. Department of Agriculture, Forest Service General Technical Report GTR-6, 29 p.
Smith, S.M., and Prestegaard, K.L., 2005, Hydraulic performance of a morphology-based stream channel design: Water Resources Research, v. 41, W11413, doi:10.1029/2004WR003926, 17 p.

Stevens, M.R., Diaz, Paul, and Smits, D.E., 2008, Evaluation of the acoustic Doppler velocity meter for computation of discharge records at three sites in Colorado, 2004-2005: U.S. Geological Survey Scientific Investigations Report 2007-5236, 24 p.

Stevens, M.R., and Sprague, L.A., 2003, Hydrology and water-quality characteristics of Muddy Creek and Wolford Mountain Reservoir near Kremmling, Colorado, 1990 through 2001: U.S. Geological Survey Water-Resources Investigations Report 2003-4073, 82 p.

Whiting, P.J., and Bradley, J.B., 1993, A process-based classification system for headwater streams: Earth Surface Processes and Landforms, v. 18, p. 603-612.

Wiberg, P.L., and Smith, J.D., 1987, Calculations of the critical shear stress for motion of uniform and heterogeneous sediments: Water Resources Research, v. 23, no. 8, p. 1471-1480.

Wilcock, P.R., 1992, Flow competence-A criticism of a classic concept: Earth Surface Processes and Landforms, v. 17, p. 289-298.

Wilcock, P.R., and McArdell, B.W., 1993, Surface-based fractional transport rates-Mobilization thresholds and partial transport of a sand-gravel sediment: Water Resources Research, v. 29, no. 4, p. 1297-1312.

Wilcock, P.R., and Southard, J.B., 1988, Experimental study of incipient motion in mixed-size sediment: Water Resources Research, v. 24, no. 7, p. 1137-1151.

Wolman, M.G., 1954, A method of sampling coarse river-bed material: American Geophysical Union Transactions, v. 35 , p. 951-956.

Publishing support provided by:

Denver Publishing Service Center, Denver, Colorado

For more information concerning this publication, contact:

Director, USGS Colorado Water Science Center

Box 25046, Mail Stop 415

Denver, CO 80225

(303) 236-4882

Or visit the Colorado Water Science Center Web site at:

http://co.water.usgs.gov/

This publication is available online at:

http://pubs.usgs.gov/sir/2010/5183/ 
$\frac{1}{0}$

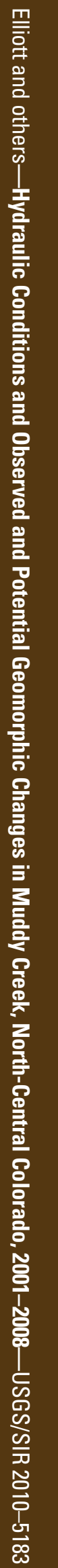

